\title{
PRESERVAÇÃO DA IDENTIDADE DE GRÃOS E A COORDENAÇÃO DOS SISTEMAS AGROINDUSTRIAIS
}

\section{EDUARDO LUIS LEĀO DE SOUSA}

Engenheiro Agrônomo

Orientador: Professor Dr. PEDRO VALENTIM MARQUES

Tese apresentada à Escola Superior de Agricultura "Luiz de Queiroz", Universidade de São Paulo, para obtenção do título de Doutor em Ciências, Área de Concentração: Economia Aplicada.

PIRACICABA

Estado de São Paulo - Brasil

Janeiro de 2001 


\section{Dados Internacionais de Catalogação na Publicação (CIP) DIVISĀO DE BIBLIOTECA E DOCUMENTAÇĀO - Campus "Luiz de Queiroz"/USP}

\section{Sousa, Eduardo Luis Leão de}

Preservaçāo da identidade de grāos e a coordenaçāo dos sistemas agroindustriais / Eduardo Luis Leão de Sousa. - - Piracicaba, 2001.

$167 \mathrm{p}$.

Tese (doutorado) - Escola Superior de Agricultura Luiz de Queiroz, 2000. Bibliografia.

1. Certificação 2. Controle de qualidade 3. Economia de Custos de Transação 4. Grāo 5. Segurança alimentar 6. Sistema agroindustrial I. Titulo

CDD 338.171521

"Permitida a copia total ou parcial deste documento, desde que citada a fonte $\mathrm{O}$ autor" 
À minha familia, exemplo inconteste de amor e união, ofereço este trabalho

À Patricia, Anna Carolina e Anna Elisa, dedico, com carinho 


\section{Agradecimentos}

Ao Professor Dr. Pedro Valentim Marques, pela orientação segura e pelo estímulo e confiança constantes depositados em meu trabalho. A convivência e amizade com o Professor Pedro, desde o período do mestrado, foi experiência profundamente edificante e enriquecedora; pela sua competência profissional e figura humana de grande dignidade, todo o meu respeito e admiração.

A todo o corpo docente do Departamento de Economia, Administração e Sociologia Rural - DEASR e, em especial, ao Professor Dr. Marcos Sawaya Jank, pelo incentivo, amizade e contribuições valiosas ao presente trabalho. Tem sido, para mim, um exemplo permanente de dinamismo, dedicação e brilhantismo acadêmico e profissional. Destaco, também, as importantes sugestões do Professor Evaristo Marzabal Neves para a presente tese.

Aos colegas e professores do Programa de Estudos de Negócios Agroindustriais, PENSA/USP, pelo exemplo de trabalho em equipe e pelo convívio acadêmico estimulante. Gostaria de registrar um agradecimento especial ao coordenador do Programa, Professor Dr. Decio Zylbersztajn, fonte renovada de inspiração para os que o cercam. As disciplinas ministradas por ele foram de importância ímpar para o desenvolvimento da idéia e formatação teórica deste trabalho. Da mesma forma, ressalto particular homenagem aos valorosos ensinamentos da coordenadora-adjunta do PENSA, a Professora Dra. Elizabeth M. M. Q. Farina. A possibilidade do convívio acadêmico com a Professora Beth tem representado, para mim, motivo do mais elevado orgulho e de ampliação de fronteiras.

Mais dois pesquisadores do PENSA merecem um registro especial e o meu reconhecimento: a Professora Dra. Maria Sylvia M. Saes, pelo seu constante entusiasmo e incansável busca e ampliação de novos horizontes, e o Professor Dr. Rubens Nunes, pesquisador pertinaz, incansável estudioso, debatedor 
ardoroso. A amizade, a convivência e o intercâmbio constante de idéias que tenho com Sylvia e Rubens, desde o período em que trabalhamos na Fundação Instituto de Pesquisas Econômicas - FIPE/USP, são, para mim, motivo de grande orgulho e satisfação.

Aos colegas da Secretaria de Acompanhamento Econômico, do Ministério da Fazenda e, em especial ao Secretário Claudio Monteiro Considera, pelo incentivo permanente e grande exemplo de seriedade e competência na formulação e condução de políticas públicas.

A todos os colegas do curso de doutorado, pelo companheirismo e compartilhamento de ideais, especialmente a Silvia Helena Galvão de Miranda e Augusto Hauber Gameiro, companheiros constantes e amigos fraternos, com quem compartilhei momentos de intensa, desafiante e, acima de tudo, gratificante atividade profissional, na Federação da Agricultura do Estado de São Paulo - FAESP.

À Srta. Ligiana Clemente do Carmo, bibliotecária da Biblioteca do DEASR da ESALQ/USP, pela revisão competente das referências bibliográficas e à Professora Graciema Pires Therezo, pela cautelosa e atenta revisão ortográfica deste trabalho.

A todos os funcionários do DEASR, pela constante atenção e, em especial, às secretárias Maria Aparecida Maielli Travalini e Cristiane Cipriano, pelo auxílio competente e atenciosa colaboração, ao longo de todo o curso.

À Capes, pela bolsa de estudos concedida durante o primeiro ano do curso de doutorado.

A todos aqueles que direta ou indiretamente, contribuíram para a conclusão deste trabalho, registro meu agradecimento. 
SUMÁRIO

Página

LISTA DE ABREVIATURAS ............................................................... vii

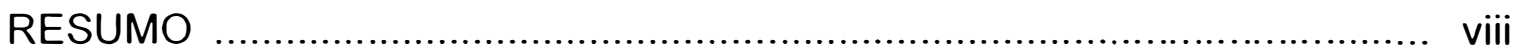

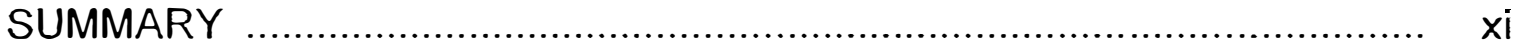

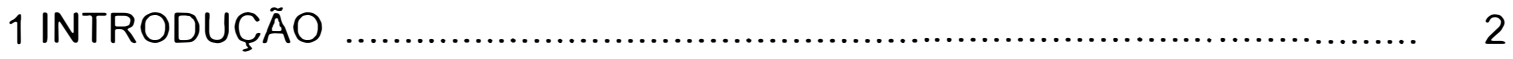

1.1 Objetivo e Hipótese ............................................................. 9

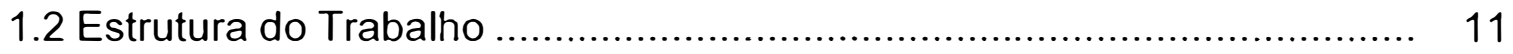

2 ECONOMIA DE CUSTOS DE TRANSAÇÃO E RELAÇÕES

CONTRATUAIS NOS SISTEMAS AGROINDUSTRIAIS ........................ 14

2.1 Economia dos custos de transação ................................................ 14

2.2 Alterações nos atributos e a estrutura de governança dos SAGs .......... 29

2.2.1 Formas de governança no mercado de commodities ....................... 30

2.2.2 Formas de governança no mercado de produtos diferenciados ......... 33

2.3 Sub-sistemas estritamente coordenados …................................... 36

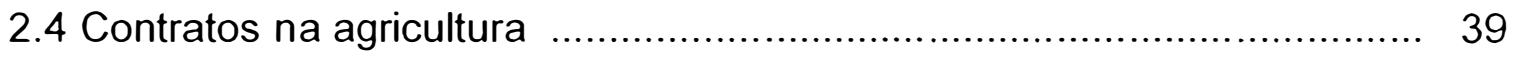

3 CARACTERISTICAS DAS TRANSAÇÕES E A COORDENAÇÃO

DOS SISTEMAS AGROINDUSTRIAIS ............................................ 45

3.1 Custos da informação .............................................................. 47

3.2 Custos da negociação .................................................................... 50

3.2.1 Custos de reconversão e de operacionalização produtiva do sistema de PI 
3.2.2 Custos do desenho do contrato

3.3 Custos de monitoramento 60

3.3.1 Padronização e certificação

3.3.2 Rastreabilidade 71

3.4 Custos de transação e os arranjos contratuais 76

4 MATERIAL E MÉTODOS 82

5 ESTUDOS EMPÍRICOS 91

5.1 Terra Preservada (soja orgânica) 92

5.2 llycaffè (cafés especiais) 99

5.3 Corn Products (milho waxy ou ceroso) 105

5.4 Du Pont (High Oil de milho) 112

5.5 Genetic ID 118

6 RESULTADOS E DISCUSSÃO 129

7 CONCLUSÕES 147

7.1 Conclusões gerais 147

7.2 Comentários finais e propostas de novas pesquisas 151

8. REFERÊNCIAS BIBLIOGRÁFICAS 154 APÊNDICE 166 


\section{LISTA DE ABREVIATURAS}

ABIC Associação Brasileira da Indústria de Café

ABIOVE Associação Brasileira das Indústrias de Óleos Vegetais

ACARPA Associação dos Produtores da Região de Patrocínio

ADM Archer Daniels \& Midland Company

CONAB Companhia Nacional de Abastecimento

EUA Estados Unidos da América

HOC High Oil Corn (milho com alto teor de óleo)

IBD Instituto Biodinâmico

IFOAM International Federation of Organic Agriculture Movement)

NIRT Near Infra-Red Technology)

OGM Organismo Geneticamente Modificado

OSCAR Optimum Sales Connection and Resource

PI Preservação da Identidade

PCR Polymerase Chain Reaction

SAG Sistema Agroindustrial

TI Tecnologia da Informação

UE União Européia

USDA United States Department of Agriculture 


\title{
PRESERVAÇÃO DA IDENTIDADE DE GRÃOS E A COORDENAÇÃO DOS SISTEMAS AGROINDUSTRIAIS
}

\author{
Autor: EDUARDO LUIS LEÃO DE SOUSA \\ Orientador: Prof. Dr. PEDRO VALENTIM MARQUES
}

\section{RESUMO}

O presente trabalho investigou o papel da coordenação e da busca de eficiência sistêmica frente aos novos desafios e transformações decorrentes da necessidade da preservação de identidade de grãos, que passam a contar com atributos diferenciados. Essa mudança percorre toda a cadeia produtiva, desde a indústria de sementes - responsável por importantes inovações tecnológicas até o consumidor final, cada vez mais exigente quanto a questões relacionadas à segurança do alimento e práticas agrícolas sustentáveis .

Um novo arranjo no sistema estará vinculado à capacidade dos diversos agentes dos sistemas agroindustriais de coordenar e gerenciar essas relações, principalmente por meio do desenvolvimento de mecanismos de incentivos e controle, incluindo formas eficientes de rastreabilidade e certificação do produto ao longo da cadeia. Estes últimos terão um papel fundamental na diminuição da assimetria informacional entre produtores e consumidores.

O arcabouço teórico utilizado foi a Economia de Custos de Transação, que permitiu a fundamentação e sistematização da análise, validada pelos estudos de casos que envolveram situações de Preservação de Identidade no Brasil e no exterior. Assim, foram analisadas cinco empresas que trabalhavam com grãos diferenciados e utilizavam sistemas de segregação e instrumentos de incentivos e monitoramento ao produtor rural. Os produtos estudados foram os 
seguintes: soja orgânica, cafés especiais, milho ceroso (ou waxy), milho com elevado teor de óleo e soja transgênica.

Verificou-se que, realmente, a tendência de segregação de produtos implica a necessidade de adaptações e de alteração na forma de governança, via mercado, até então predominante. Os contratos podem ter várias formas, dependendo das características da transação. A preservação de identidade também implica aumento nos custos, que permeiam todas as fases da cadeia produtiva. Esses custos são identificáveis e têm forte relação com as características das transações e com os atributos do produto que se deseja segregar. Os custos adicionais de produção, distribuição e processamento vão depender, basicamente, das seguintes características: tolerância à contaminação, aspectos agronômicos, especificidade temporal e quantidade de produtos derivados.

Identificou-se também que as estratégias de incentivo e monitoramento são fundamentais para o sucesso do sistema de PI. Os incentivos vão estar diretamente relacionados aos custos e à incerteza da transação e o monitoramento está fortemente relacionado ao nivel de assimetria informacional que, por sua vez, associa-se aos atributos do produto.

Assim, produtos cujo atributo é facilmente identificável requerem um nivel de monitoramento distinto daqueles em que não se percebem, facilmente, as qualidades desejáveis. Em situações de baixo grau de diferenciação do produto, a assimetria informacional é praticamente nula, sendo o mercado considerado como a estrutura associada ao menor custo de transação. Com o aumento da diferenciação do produto, ocorre, também, o aumento da inabilidade do mercado para lidar com adaptações, sugerindo o estabelecimento de contratos entre as partes. Na situação em que o produto é diferenciado, porém facilmente identificável - com atributos visiveis ou facilmente perceptiveis -, as formas contratuais entre as partes são a maneira 
mais eficiente de monitoramento. Na medida em que a assimetria informacional aumenta, o mercado já demanda processos de certificação que permitam diminuir as incertezas do comprador, seja quanto ao produto, seja ao processo. Se facilmente identificável por testes laboratoriais, a certificação ao produto é a mais desejável; caso contrário, a certificação ao processo é a que minimiza os custos de monitoramento. Finalmente, em algumas situações, em que a não observância dos atributos pode gerar riscos à saúde ou em que há necessidade de identificação da origem de um determinado lote do produto, são necessários processos de rastreabilidade. 


\title{
IDENTITY PRESERVATION OF GRAINS AND THE COORDINATION OF AGROINDUSTRIAL SYSTEMS
}

\author{
Author: EDUARDO LUIS LEÃO DE SOUSA \\ Adviser: Prof. Dr. PEDRO VALENTIM MARQUES
}

\section{SUMMARY}

The present thesis investigated the role of coordination and pursuit of systemic efficiency in the face of the new challenges and transformations resulting from the need to preserve the identity of grains. This change traverses the entire productive chain, from the seeds industry - responsible for important technological innovations - to the final consumer, ever more demanding in terms of issues related to food safety and sustainable agricultural practices.

A new arrangement in the system will be linked to the capacity of the various agents of the agroindustrial systems to coordinate and manage these relationships, mainly by means of the development of mechanisms of incentives and control, including efficient forms of traceability and certification of the product throughout the chain. The latter will play a fundamental role in diminishing the information asymmetry between producers and consumers.

The theoretic framework utilized was Transaction Cost Economics, which allowed the foundation and systematization of the analysis, validated by case studies that involved situations of Identity Preservation in Brazil and abroad. Thus, five firms that work with differentiated grains and utilized segregation systems, incentives and monitoring of rural producers were analyzed. The products studied were the following: organic soy, special coffees, waxy corn, corn with high oil level, and genetic modified soy. 
It was verified that, indeed, the trend toward product segregation involves the need for adaptations and alteration in the predominating governance form. The contracts can take several forms, depending on the characteristics of the transaction. Identity preservation also involves increased costs, which permeate all phases of the productive chain. These costs are identifiable and have a strong relationship to the characteristics of the transactions and to the attributes of the product one wishes to segregate. The additional production, distribution, and processing costs will depend basically on the following characteristics: tolerance to contamination, agronomic aspects, temporal specificity and amount of derived products.

The thesis also identified that incentive and monitoring strategies are fundamental for the success of the identity preserved (IP) system. The incentives will be directly related to the costs and uncertainty of the transaction and the monitoring is strongly related to the level of information asymmetry which, in turn, is associated to the product attributes.

Hence, products whose attributes are easily identifiable require a level of monitoring distinct from that in which one cannot easily perceive the desirable qualities. In situations of low level of product differentiation, information asymmetry is practically null, and the market is the structure associated to the lowest transaction cost. With the increase of product differentiation, there is also an increase in the inability of the market to deal with adaptations, suggesting the establishment of contracts between the parties. In the situation where the product is differentiated, but easily identifiable - with visible or easily perceivable attributes -, contract forms between the parties are the most efficient means of monitoring. Insofar as information asymmetry increases, the market demands certification processes, either for the product or for the process, that allow a diminution of buyer uncertainties. If easily identifiable by lab tests, product certification is the most desirable; otherwise, process certification is the best way to lower monitoring costs. Finally, in some situations, where non-observance of 
the attributes can generate health risks or where there is a need to identify the origin of a given lot of the product, the need for traceability processes emerges. 


\section{INTRODUÇÃO}

O presente estudo pretende analisar as estruturas de governança e arranjos contratuais mais eficientes - i.e. minimizadores de custos de transação - dos sistemas agroindustriais de grãos em situações em que há a necessidade da preservação da sua identidade ${ }^{1}$. Serão avaliados mecanismos de incentivos e controles, em situações de diferentes níveis de assimetria informacional e custos de transação envolvidos, a partir de estudos empíricos - analisando casos nacionais e internacionais -, com ênfase nas relações produtor ruralagroindústria.

A crescente preocupação do consumidor com a segurança do alimento e com as questões sócio-ambientais, aliada às inovações tecnológicas - a exemplo da engenharia genética e tecnologia da informação - e às transformações regulatórias, sugere o desenvolvimento de um novo paradigma nas relações entre os diversos segmentos que compõem os sistemas agroindustriais ${ }^{2}$ (SAGs). O fluxograma simplificado de um SAG tradicional pode ser visualizado na Figura 1.

\footnotetext{
${ }^{1}$ A expressão Preservação de Identidade (PI) será entendida, ao longo deste trabalho, como a capacidade de identificar, manter e segregar um determinado atributo ao longo de toda a cadeia produtiva.

${ }^{2}$ Goldberg (1968) define o Sistema Agroindustrial como o conjunto de todos os participantes envolvidos na produção, processamento e comercialização de um determinado produto agrícola. Inclui empresas de insumos, produtores rurais, operações de armazenagem, processadores, atacadistas e varejistas envolvidos no fluxo de produção desde a produção de insumos até o consumidor final. Compreende, também, todas as instituições que afetam a coordenação e estágios sucessivos do fluxo de produção.
} 


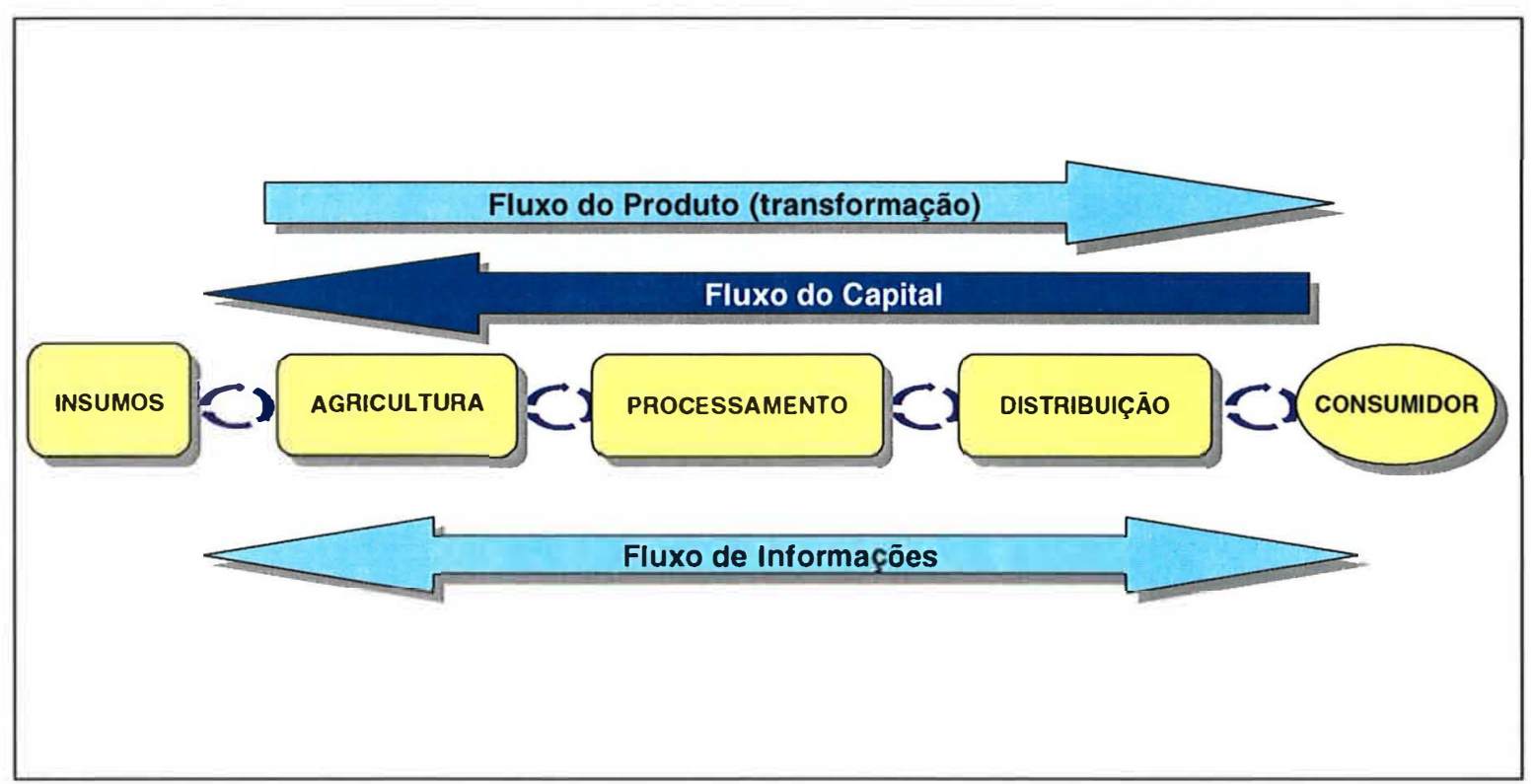

Fonte: Elaborado pelo autor

Figura 1. Fluxograma simplificado de um sistema agroindustrial (SAG).

O sistema de comercialização de grãos, até o presente momento, sempre esteve associado a produtos de baixa especificidade. Produtos como a soja ou - milho sempre foram considerados commodities, portanto sem qualquer diferenciação ao consumidor, desde que atendessem a normas de padrões e qualidade mínimos, independente de sua origem, condições de plantio e/ou conteúdo genético. Essa característica, segundo a teoria da Economia de Custos de Transação, sugere que a forma mais eficiente de comercialização seja por meio de negociações via mercado, impessoais, em que o principal atributo do produto é o preço, fixado conforme as condições de oferta e demanda. Na falta de algum tipo de especificidade da matéria-prima agrícola, a sinalização via mercado tem sido suficiente, já que o produto é homogêneo e os preços contêm toda a informação de que os produtores necessitam para escolher o plano de produção mais adequado. Além disso, em função da própria estrutura de mercado na produção agrícola, o produtor tem pouco ou nenhum poder de barganha. 
A tendência da produção de grãos com atributos específicos para atender a determinados nichos de mercado - como a diferenciação do sabor ou do teor protéico de alimentos - implicará uma maior dependência entre produtores e compradores, sugerindo o estabelecimento de contratos, quer formais, quer informais, como forma de minimizar os custos de transação ${ }^{3}$. Nessa situação, os ativos transacionados são mais específicos (no que tange a características físicas, localização da produção, sazonalidade etc) e o grau de incerteza associado à transação é mais elevado.

De fato, espera-se que, para produzir um produto diferenciado, o empresário rural deva exigir maior garantia de venda, além de um prêmio associado ao seu risco de comercialização, em muitos casos. Em condições de mercado, o produtor dessa matéria-prima poderia se tornar refém da indústria processadora, dada a especificidade do produto. A indústria, por sua vez, teria uma maior dependência dessa matéria prima, adequada ao seu processo industrial, para assegurar o fluxo contínuo de produtos diferenciados ao mercado.

Brester et al. (1996), analisando a Associação de Triticultores dos EUA, confirmam que as características das novas variedades de grãos irão gerar o desenvolvimento de novos arranjos de mercados, já que os sistemas tradicionais de comercialização não são capazes de preservar a identidade de grãos diferenciados e não resolvem o problema do aumento dos riscos associados à transação. Os autores constatam que as transformações desses sistemas serão determinadas pelos custos de transação envolvidos e que, embora o início dessas mudanças esteja vinculado a aspectos genéticos, as variáveis econômicas condicionarão a sustentabilidade dessas mudanças.

\footnotetext{
${ }^{3}$ A título de ilustração, a U.S. Grains Council afirma que entre 1995 e 2000 , houve um incremento de $42 \%$ na área plantada de milho branco nos Estados Unidos e 300\% de milho com alto teor de óleo. A adoção do uso de soja transgènica também teve um grande impulso neste período. Segundo o United States Department of Agriculture (USDA), aproximadamente 60\% da área plantada de soja nos EUA em 1999, era composta por soja transgênica.
} 
Assim, transações que eram definidas originalmente por padrões de preços, quantidade e qualidade internacionalmente definidos e aceitos, tornam-se crescentemente multidensionais, com vários atributos de qualidade relevantes. A necessidade de segregação, ou de preservação de identidade, e de proteção à propriedade intelectual que passam a ser associadas aos grãos, cria uma necessidade de infra-estrutura e de recursos de gerenciamento inéditos tanto para produtores quanto para compradores.

Sob a ótica macroeconômica, a Figura 2 demonstra as duas situações distintas de equilibrio das curvas de oferta e demanda. No primeiro caso, observa-se o equilibrio em um mercado de commodity $(M)$, para uma determinada curva de oferta $O_{M}$ e de demanda $D_{M}$. Na situação 2, é apresentado o mercado da mesma commodity, porém com diferenciação no produto. Assumindo-se que a demanda seguiria o mesmo padrão inicial (hipótese improvável, somente para efeito de simplificação da análise), são introduzidos novos custos adicionais ao processo, referentes à segregação e preservação de identidade (PI). Como conseqüência do aumento do custo de produção unitário, espera-se um deslocamento da curva de oferta do produto diferenciado para a esquerda, de $\mathrm{O}_{\mathrm{M}}$ para $\mathrm{O}_{\mathrm{Pl}}$, com uma situação de equilibrio de menor oferta e maior preço. $A$ um mesmo preço do produto, os produtores estariam dispostos a oferecer uma menor quantidade. A utilização de mecanismos redutores de custos de transação, analisados neste trabalho, teria o papel de deslocar a curva para a direita e, consequentemente, reduzir o preço e elevar a oferta do produto diferenciado. 

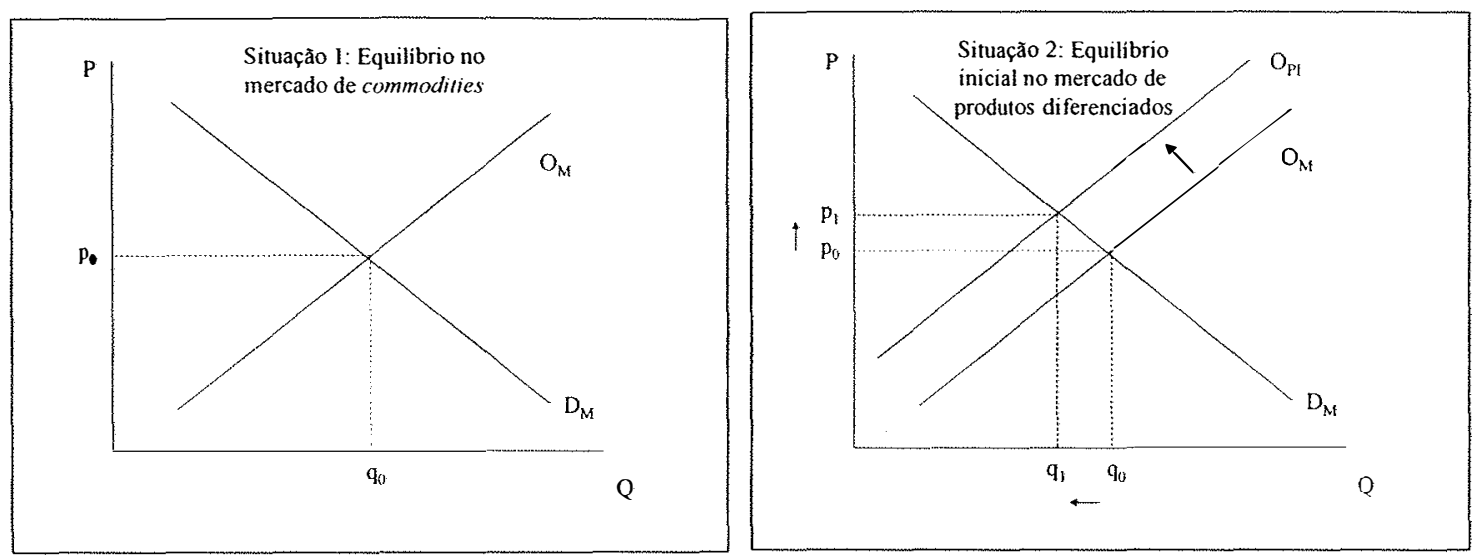

Figura 2. Efeitos econômicos no mercado de produtos com Preservação de Identidade.

Associado ao aumento de custos e mecanismos de segregação do produto, surge também a necessidade de processos de certificação e rastreamento do produto nas distintas etapas do SAG, de forma a se monitorar o seu caminho e garantir os padrões de qualidade requeridos pelo consumidor final. O grande desafio refere-se a como fazer com que, por exemplo, uma soja orgânica produzida no Sudoeste do Paraná chegue a lojas do varejo no mercado japonês, sob a forma de tofu ${ }^{4}$, pelo menor custo, e com a garantia de que o produto não teve contato com qualquer produto químico ao longo da cadeia produtiva. Há, ainda, a necessidade de que o consumidor daquele pais acredite nessa informação, visto que essa característica não é facilmente percebida pelo consumidor. Faz-se necessário, então, a presença de um selo de certificação para aquele produto final que ofereça essa sinalização ao usuário final.

\footnotetext{
${ }^{4} \mathrm{O}$ tofu constitui um alimento amplamente utilizado na cozinha japonesa, preparado à base de leite de soja e coagulantes, guardando semelhança com o queijo fresco.
} 
A mesma situação valeria, também, para a carne de frango vendida em um supermercado europeu com a garantia de que o produto é livre de organismos geneticamente modificados (OGMs) $)^{5}$. Para tanto, é necessário que haja o acompanhamento e rastreamento de toda a cadeia de produção, desde a produção da soja e do milho que vão compor a ração consumida pela ave até a gôndola do supermercado. Esse processo ganha importância na medida em que aumenta a conscientização da população quanto à qualidade e procedência do alimento que consome. Ilustrativa é a pesquisa desenvolvida pela Louis Harris (Bloomberg News, 2000), que aponta a segurança alimentar como "a maior preocupação dos franceses, ficando acima do desemprego, da violência e da poluição" e identifica os produtos transgênicos como um dos mais fortemente rejeitados por aqueles consumidores.

É importante ressaltar que essa estrutura, envolvendo o sistema de preservação de identidade, só se justifica se os custos adicionais associados a esse processo forem absorvidos pelos elos da cadeia. De fato, Hayes et al. (2000) analisaram os resultados da utilização de uma determinada variedade de milho com maior teor de proteína na ração animal, o que resultou em significativos ganhos de conversão para bovinos, aves e suínos. Por outro lado, quando se consideraram os custos totais para se produzir e preservar a identidade desse produto, verificou-se que eles não seriam suportados pela indústria bovina e suina. Outros benefícios deveriam ser agregados para que se viabilizasse a sua utilização, ou mecanismos minimizadores de custos de transação deveriam, necessariamente, ser associados ao processo.

\footnotetext{
${ }^{5}$ Produtos geneticamente modificados, também chamados de transgênicos, são todos aqueles organismos que apresentam características agronômicas ou pecuárias distintas das originais, pela incorporação de genes provenientes de outros organismos, por meio de técnicas não-convencionais de cruzamento. Nos processos tradicionais, esse cruzamento de genes ocorre apenas entre espécies similares. Exemplos são a inserção de genes de peixe em tomates, para aumentar sua "vida de prateleira", ou no caso de grãos, a soja Round-up Ready (resistente ao herbicida à base do princípio ativo Glifosato) e o milho BT, resistente aos ataques de algumas pragas que danificam a cultura desse cereal.
} 
A Figura 3 sintetiza os principais conceitos abordados nesta introdução. A partir da manifestação de novos desejos e/ou exigências dos consumidores e do desenvolvimento da engenharia genética, surgem novos atributos para produtos, antes, sem diferenciação. Essas novas características demandam processos de segregação, a partir de mecanismos de coordenação do sistema. Finalmente, essa informação deve ser transmitida aos consumidores finais, que passam a demandar novos atributos, fechando-se, então, o ciclo.

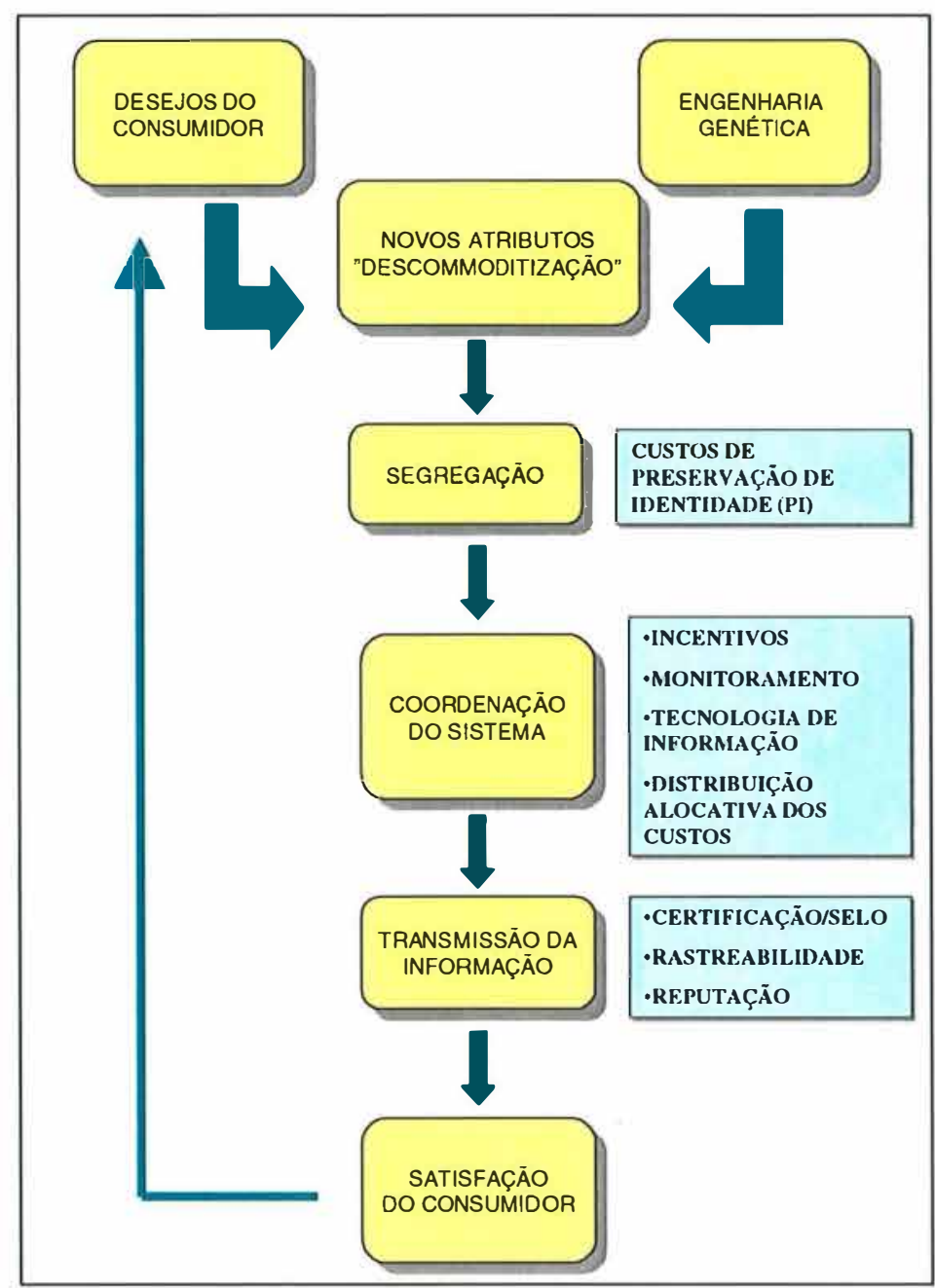

Fonte: elaborado pelo autor

Figura 3. Esquema simplificado do processo de PI 
Assim, este trabalho se insere na análise de Verheijden \& Ortiz (1999) que afirmam que, com o aumento da especificidade dos produtos, deve haver uma importante mudança nas estratégias de parte das empresas envolvidas nos SAGs de grãos: o modelo atual, caracterizado por baixas margens, grandes volumes físicos e estratégias cujo foco é a liderança em custos, passa a coexistir com sub-sistemas que envolvem um produto de maior valor agregado, menores volumes e maior especificidade nas transações. $O$ foco das estratégias dessas empresas torna-se a liderança em diferenciação e será objeto de análise do presente estudo.

\subsection{Objetivo e Hipótese}

O objetivo principal deste trabalho será, então, o de identificar quais são as estruturas de governança e formas de monitoramento e incentivos mais eficientes que minimizem custos e falhas de transação e que atendam à necessidade de se manter a Preservação da Identidade $(\mathrm{PI})$ dos diversos tipos de grãos - como a soja, o milho ou o café. Essa análise será desenvolvida, considerando as distintas características e custos associados às transações que envolvem os diferentes produtos e/ou SAGs analisados.

Pretende-se sistematizar o conhecimento de conceitos teóricos, relacionados ao processo de coordenação de Sistemas Agroindustriais, conjugado com a análise descritiva de experiências empíricas e emergentes de Preservação de Identidade de grãos. Apesar de este processo ocorrer em todas as fases do Sistema, será enfatizada a relação produtor-agroindústria.

Os objetivos específicos serão:

- identificar os custos associados ao sistema de PI;

- analisar as interfaces e complementariedades existentes entre as 
estratégias das empresas utilizadas na identificação de produtos, tais como rastreabilidade, certificação e tecnologia de informação (TI), assim como os instrumentos de incentivos e controles;

- descrever e analisar experiências recentes que envolvam Preservação da Identidade, observando-se os atributos das transações e estratégias adotadas, dados os distintos ambientes institucionais nos quais estas transações ocorrem;

- propor novos temas de pesquisa para esta área do conhecimento, que se configura como uma das inequívocas tendências no mercado de grãos e, ao mesmo tempo, um dos importantes desafios para os agentes desse mercado.

A premissa central do trabalho baseia-se no fato de que, em situações em que há necessidade de Preservação de Identidade de grãos, ocorre significativo aumento dos custos de transação. Dessa forma, tem-se como hipóteses $\left(H_{0}\right)$ :

i) que as formas de minimizar os custos envolvidos no processo de $\mathrm{PI}$ dependem das caraterísticas das transações e dos atributos dos produtos e implicam o estabelecimento de arranjos contratuais (formas híbridas), sejam formais ou informais,

ii) em função dos atributos específicos dessas transações e dos produtos envolvidos, haverá a utilização de distintos mecanismos de incentivo, monitoramento e tecnologia de informação para a Preservação de Identidade, e

iii) a existência de bens públicos e coletivos representam importante redutor nos custos de transação para a PI, atuando, principalmente, na diminuição da assimetria informacional. 


\subsection{Estrutura do Trabalho}

O presente estudo foi divido em sete capítulos, da seguinte forma:

1. Introdução

2. Revisão bibliográfica da Economia de Custos de Transações (ECT), ferramental que será utilizado - juntamente com conceitos de Organização Industrial - como arcabouço teórico do presente estudo. Em seguida, será utilizado o modelo teórico para uma aplicação prática para os SAGs, em situações em que há o aumento da especificidade dos atributos. Como desdobramento dessa teoria, será discutido o conceito de sub-sistemas estritamente coordenados que, sob determinadas condições, permitem a coexistência de estruturas de governança diferenciadas dentro do mesmo SAG. Complementando este capítulo, serão apresentadas algumas considerações sobre as formas de contrato na agricultura.

3. Discussão sobre a coordenação, identificando as características da transação - associadas a custos de informação, negociação e monitoramento - consideradas relevantes para o estabelecimento da forma de governança mais eficiente. Dadas essas características e um determinado aparato institucional, será sistematizada a metodologia utilizada para se determinar e avaliar os tipos de arranjos contratuais mais eficientes - como instrumentos de incentivos, controle e tecnologia de informação - em condições de necessidade de preservação de identidade de grãos.

4. Descrição dos materiais e métodos propostos para a análise do presente estudo.

5. Estudos de casos que envolvem diferentes atributos das transações e formas de coordenação. Pretende-se, empiricamente, identificar os principais atributos - dado um determinado ambiente institucional - e avaliar 
a eficiência das estruturas de governança adotadas, segundo o modelo apresentado no capítulo quatro.

6. Apresentação de resultados e discussões da pesquisa, segundo a teoria proposta nas segunda e terceira partes, as quais se pretende validar a partir das experiências empíricas analisadas na quinta parte do trabalho.

7. Conclusão: resultados da pesquisa e sugestões para o desenvolvimento de novos trabalhos. 
2 ECONOMIA DE CUSTOS DE TRANSAÇÃO E RELAÇÕES CONTRATUAIS NOS SISTEMAS AGROINDUSTRIAIS 


\section{ECONOMIA DE CUSTOS DE TRANSAÇÃO E RELAÇÕES CONTRATUAIS NOS SISTEMAS AGROINDUSTRIAIS}

Este capítulo pretende fazer uma revisão teórica dos conceitos relevantes para a análise da coordenação dos SAGs e sua aplicação. Inicialmente, há uma breve revisão de Nova Economia Institucional - NEI, enfatizando aspectos da Economia dos Custos de Transação - ECT, face às estratégias empresariais que se pretendem avaliar. No item 2.2, ainda segundo a ótica da ECT, é desenvolvida uma discussão sobre a estrutura de governança esperada ${ }^{6}$ para os sistemas agroindustriais em que há aumento da especificidade dos ativos. No item 2.3, discute-se o desenvolvimento de sub-sistemas, com estruturas de governança diferenciadas, que passam a ocorrer dentro de alguns sistemas agroindustriais. Finalmente, no item 2.4 , é desenvolvida uma discussão sobre os contratos na agricultura.

\subsection{Economia dos Custos de Transação}

Neste primeiro item, serão apresentados os principais fundamentos da chamada Nova Economia Institucional, enfocando seus dois níveis analíticos distintos: o primeiro, que traz uma abordagem macroanalítica, avalia o papel das instituições, ou o ambiente institucional em que ocorrem as transações

\footnotetext{
${ }^{6}$ Entende-se por governança como a matriz institucional na qual a transação é definida (Williamsom, 1985). É a forma utilizada para organizar a produção, cujas modalidades serão descritas neste capítulo.
} 
entre indivíduos ou empresas, tendo os trabalhos de Douglass North, como principal referência; o segundo, que traz uma abordagem microanalítica, analisa as relações entre as empresas sob a ótica dos custos de transação. Destacase, aí, o papel de Oliver Williamson, pelos trabalhos desenvolvidos nesta área, retomando as pesquisas iniciais de Ronald Coase, pioneiro nos estudos da NEI, cujos primeiros trabalhos remontam ao final da década de 30 .

Como proposição fundamental da teoria da ECT, a transação constitui-se na unidade básica de análise. Segundo Arrow (1969:68), os custos associados às transações podem ser definidos como "os custos que são necessários para se colocar o mecanismo econômico e social em funcionamento", sejam quais forem as instituições e os mecanismos de incentivo e controle adotados. Williamson (1985:19) ilustra o conceito de custos de transação como "o equivalente econômico ao atrito no sistema físico".

Devem-se destacar as dificuldades de se mensurar os custos de transação e, até mesmo, identificá-los adequadamente visto que, diferentemente dos custos de produção física, aqueles não são facilmente separáveis dos custos administrativos da atividade. Dessa forma, Hobbs (1996) procura sistematizar esses custos, dividindo-os em três tipos principais: informação, negociação e monitoramento. Custos de informação surgem no período ex ante à transação e incluem os custos de se obter os preços e as informações sobre o produto, além dos custos de identificação dos parceiros adequados para a transação. Custos de negociação são aqueles relacionados à transação física e podem incluir custos de comissão e custos físicos da negociação e da formatação do contrato mais eficiente. Finalmente, os custos de monitoramento ocorrem no período ex post e são aqueles que garantem que os termos do contrato - como padrões de qualidade ou formas de pagamento -, estão sendo cumpridos pelas partes envolvidas ${ }^{7}$.

\footnotetext{
${ }^{7}$ Para efeito de sistematização do presente estudo, será utilizada esta divisão proposta por HOBBS.
} 
Poole et al. (1998) também associam a origem dos custos de transação àqueles incorridos pelas firmas ao procurar um comprador ou vendedor, ao renegociar termos contratuais ou monitorar os contratos. Segundo os autores, esses custos seriam conseqüência, principalmente, das incertezas que decorrem das características da transação, conforme o Quadro 1.

Tipos de custos de transação

Origem: incerteza em função de

Busca de compradores ou vendedores

- Imperfeições da estrutura de mercado

- Informação limitada

Renegociação dos termos contratuais

- Oportunismo

- Informação limitada

- Complexidade dos termos contratuais

- Transações infreqüentes

Monitoramento

- Incomplitude dos termos contratuais

- Oportunismo

- Informação limitada

Fonte: Poole et al. (1998)

Quadro 1. Características das transações e origem dos custos de transação.

A teoria da ECT sustenta que são as características das transações que irão condicionar a forma de governança mais eficiente, ou aquela que se espera como redutora dos custos de transação. Zylbersztajn (1995, p. 137) sugere que os "SAGs podem ser analisados como conjuntos de transações onde as estruturas de governança prevalecentes são um resultado otimizador do alinhamento das características das transações e do ambiente institucional". 
Segundo o autor, a otimização, nesta análise, teria o mesmo significado da busca da eficiência presente na análise típica neo-clássica, adicionando os custos de transação distintos de zero e o ambiente institucional não neutro.

As estruturas de governança podem ser classificadas em: i) a opção pela compra no mercado (preços); ii) a produção própria, sob a forma hierárquica ou firma (também chamada de integração vertical), e iii) a forma híbrida, baseada em contratos.

No primeiro caso, a sinalização do preço é suficiente para organizar o mercado, com o menor nível de controle. É o caso do mercado das commodities.

No outro extremo, ocorre a hierarquia (ou integração vertical). Na firma, as transações são conduzidas dentro de um regime de propriedade unificada (comprador e vendedor são da mesma empresa) e são sujeitas a controles administrativos (relação de autoridade). A integração vertical (ou firma) será preferível em situações de alta especificidade de ativos, maior incerteza e complexidade contratual. O poder impositivo da firma diminui a possibilidade de oportunismos e permite uma definição mais clara de direitos, obrigações e procedimentos. Como exemplo dentro do setor agroindustrial, pode-se citar o caso do SAG da laranja, em que há um elevado grau de verticalização da indústria, que supre grande parte do seu consumo por meio de pomares próprios. Levantamentos realizados por Siffert (1992) apontam um grau de verticalização a montante de, pelo menos, $30 \%$ para quatro das cinco maiores indústrias de suco $^{8}$. As razões desse elevado nível de verticalização encontram diversas vertentes na sua literatura: ganhos de logística e planejamento (Neves, 1995:75), existência de nichos de mercado (Andia, 1995), maior eficiência da indústria na produção agrícola de citros e motivações estratégicas, como o aumento do poder de barganha (Azevedo, 1996).

\footnotetext{
${ }^{8}$ As cinco maiores empresas de suco de laranja concentrado respondem por mais de $80 \%$ das exportações brasileiras.
} 
Já nas formas hibridas (que se situam entre os dois extremos apresentados: mercado e firma), ocorrem relações contratuais que preservam a autonomia das partes, mas que comparadas ao mercado, instituem salvaguardas específicas às transações. Nessa estrutura, ocorrem diversas formas de arranjos, desde contratos informais, passando por alianças estratégicas, contratos formais, joint ventures e franquias.

No caso dos SAGs, diversos têm sido os arranjos contratuais estabelecidos entre produtores e agroindústria visando à redução de custos de transação. Um exemplo no agribusiness brasileiro de reconhecida eficiência no que se refere a esse tipo de governança - via contratos - é o do SAG do frango. Marques (1991) analisou os contratos estabelecidos entre produtores de aves e frigoríficos, sistema amplamente difundido, principalmente na região Sul do País. O autor identifica que os objetivos dessa relação seriam principalmente os de reduzir a incerteza quanto ao preço e de garantir à indústria a qualidade e homogeneidade da produção requeridas. Jank (1996) complementa que os contratos no SAG de aves permitem ainda a obtenção regular e padronizada de matéria-prima a preços muito mais estáveis do que os praticados no mercado interno, possibilitando um melhor planejamento das exportações de aves. Além disso, essa forma contratual facilita a transferência de tecnologia e ajuda a suprir a escassez de crédito aos produtores. Nesse sentido, Hughes (1994) e Poole (1997) observam que os desafios da indústria de alimentos relacionam-se à redução das incertezas e, como conseqüência, dos custos de transação, por meio do estabelecimento de arranjos contratuais, como parcerias e alianças, a fim de atingir um maior grau de integração e eficiência.

North (1990) destaca, também, o papel do ambiente institucional como importante variável redutora de custos de transação, a exemplo da garantia de direitos de propriedade e da promoção do campo necessário para a ação dos agentes privados atuarem. Segundo este autor, o ambiente institucional pode ser conceituado como todo o conjunto de restrições (normas) construídas pelos 
seres humanos que estruturam a interação social, econômica e política, podendo ser formais (constituições, leis e direitos de propriedade) ou informais (tabus, tradições, costumes e códigos de conduta). Instituições seriam, portanto, "as regras do jogo". O ambiente institucional dá suporte às estruturas de governança que permitem intensificar a especialização e alcançar maior eficiência ${ }^{9}$.

Assim, dado um determinado ambiente institucional, as estruturas de governança serão determinadas pelas características das transações, ou seja, supõe-se que a existência de diferentes estruturas sejam explicadas pelas diferenças básicas nos atributos das transações cujas principais características são as (a) especificidades do ativo, (b) incerteza e (c) freqüência. A seguir, serão descritas cada umas destas três características:

a) Especificidade do ativo: diz respeito aos investimentos realizados em um determinado ativo e aos custos de realocação do mesmo em atividades alternativas. Assim, ativos menos específicos possuiriam uma maior possibilidade de formas alternativas de uso. A característica da especificidade da transação é descrita por Williamson (1991) como o mais importante indutor da forma de governança e pode ser classificada segundo critérios temporal, locacional, de ativos físicos, humanos, dedicados ou de marca. Williamson (1991, p. 291) descreve essas especifidades da seguinte forma:

\footnotetext{
${ }^{9}$ Um exemplo do papel do ambiente institucional na diminuição de custos de transação refere-se à normatização de padronização e classificação de produtos. Assim, a existência de sistemas de classificação e padronização adequados às necessidades específicas dos agentes representa menores custos de transação. Lazzarini et al. (1997) citam o exemplo do fim das entregas físicas do boi gordo nos contratos de mercados futuros da BM\&F, atribuído à dificuldade de sua padronização. A sua manutenção implicaria custos de arbitragens significativamente maiores do que em outras commodities negociadas em Bolsas de Futuros, como o café, por exemplo, já que existem padrões de qualidade e classificação bem definidos para esse produto.
} 
i) especificidade temporal refere-se ao grau de perecibilidade dos produtos envolvidos, bastante comum às transações envolvendo produtos agropecuários;

ii) locacional diz respeito ao grau de proximidade física dos ativos imobilizados, a partir da análise do seu custo de remodelação e/ou realocação em termos de patrimônio envolvido e despesas de transporte, como uma planta industrial especialmente projetada para um cliente específico;

iii) a especificidade física ocorre quando há, nos sucessivos estágios de produção, empecilhos de ordem física relacionados à necessidade de componentes específicos, mesmo que os ativos sejam móveis (ex: um determinado atributo de qualidade);

iv) a especificidade humana diz respeito à qualidade e grau de substitutibilidade dos recursos humanos disponiveis;

v) a especificidade dedicada ocorre quando se dedica um determinado investimento nos ativos a comprador(es) especifico(s), envolvendo riscos expost de quebra contratual; finalmente,

vi) a especificidade relacionada à marca diz respeito ao montante de capital e riscos envolvidos no uso de marcas.

Sob a ótica da especificidade de ativos, Williamson (1991) propõe um modelo, cuja forma reduzida considera três funções para os custos de transações:

$M=M(k ; \theta)$, para forma de mercado,

$H=H(k ; \theta)$, para forma hierárquica, e

$X=X(k ; \theta)$, para forma híbrida (ou contratual), onde $k$ representa o nivel de especificidade e $\theta$, o vetor de parâmetros de deslocamento. 
Assume-se, também, que:

$\mathrm{M}(0, \theta)<\mathrm{X}(0, \theta)<\mathrm{H}(0, \theta)$, e que

$M^{\prime}>X^{\prime}>H^{\prime}$, considerando a derivada da função em relação a $k$.

Assim, em níveis de baixa especificidade, o modo de mercado é a estrutura associada ao menor custo de transação. Ou seja, a sinalização do preço é suficiente para a eficiência do mercado. Com o aumento da especificidade, ocorre, também, o aumento da inabilidade do mercado para lidar com adaptações. Após um determinado nivel de k, o modo híbrido (ou contratual) torna-se mais eficiente, com o estabelecimento de incentivos e controles gerados pelos contratos. Na situação mais extrema, o modo hierárquico (ou integração vertical), a demanda por controles diretor, visando à implementação das adaptações, só pode ser suprida pela organização interna. O Gráfico 1 ilustra essa situação. 


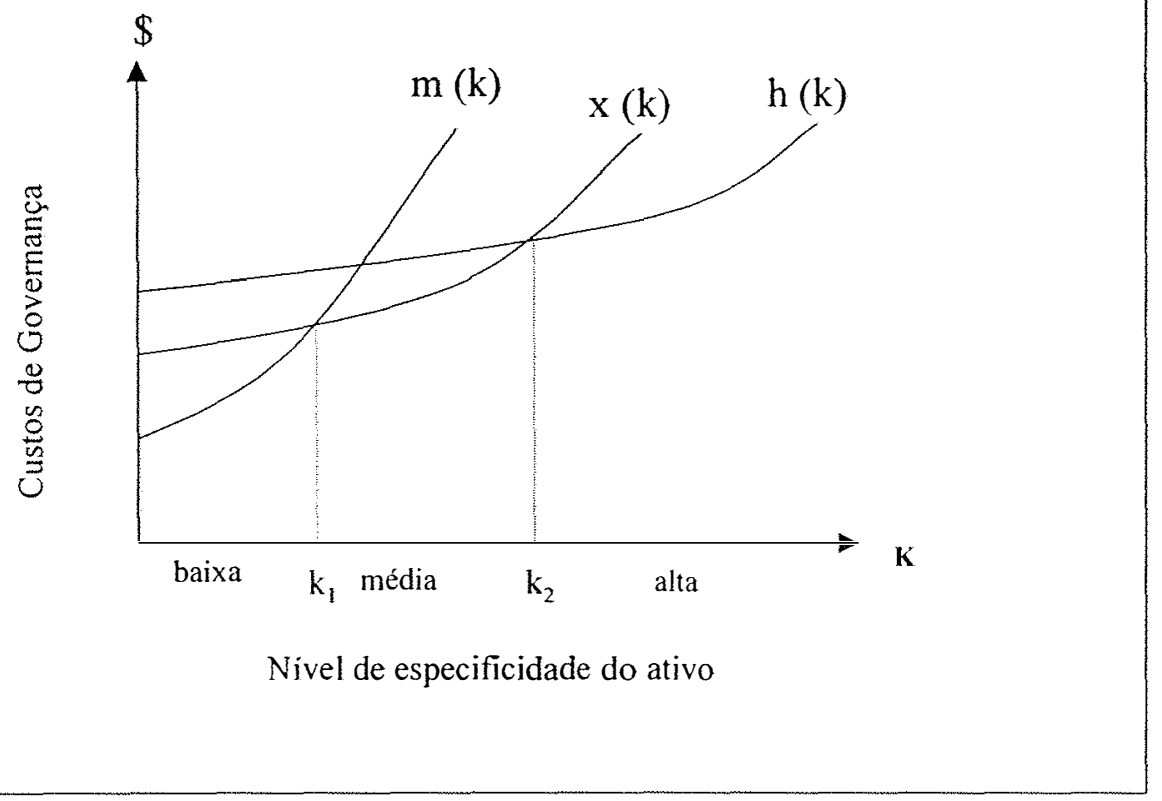

Fonte: Williamson (1991)

Gráfico 1. Curvas das funções reduzidas para os custos de transações segundo o nível de especificidade dos ativos, dada uma determinada estrutura de governança das empresas, onde: $m(k)$ - mercado; $h(k)$ hierárquica; e $x(k)$ - forma intermediária mista.

b) Incerteza: Atributo relacionado à variância ou ao desconhecimento de elementos futuros referentes à transação. Está associada à incapacidade de se prever o que pode ocorrer no ambiente de negócios, interferindo na organização e no gerenciamento dos contratos. Quanto maior for esse atributo, maior será a possibilidade de existência de distúrbios nas transações (resultantes de alterações comportamentais), alterações nas variáveis ambientais, oportunismos e outros fatores que possam alterar o curso previsto das mesmas. 
No entanto, e ainda sob a ótica da incerteza, a forma de governança esperada emerge, mais especificamente, da confluência do nivel de incerteza com o de especificidade dos ativos. Para situações de baixos niveis de especificidades, Williamson (1991) afirma que a forma de governança via mercado não será afetada pelo nivel de incerteza, já que as condições de troca para produtos do tipo commodities podem ser reorganizadas a custos desprezíveis. Para níveis intermediários de especificidade de ativos, os contratos são a forma de governança minimizadoras de custos, pois assume-se, nessa situação, que esforços de adaptação muito constantes não podem ser obtidos a custo zero no mercado. Na medida em que a especificidade aumenta, as formas de governança de mercado e híbridas perdem sua capacidade de organização quando comparadas com a forma hierárquica. De fato, o poder hierárquico da firma permite os melhores resultados a um menor custo, em niveis mais elevados de especificidade. O Gráfico 2 apresenta a proposta de Williamson.

Mariotti \& Cainarca (1986) discutiram os efeitos da incerteza sobre a estrutura de governança minimizadora de custos, analisando a evolução da cadeia têxtilvestuária na Itália. Os autores identificaram, empiricamente, que, no caso da produção de vestuários de massa - com baixa especificidade -, e à luz dos riscos relacionados à volatilidade da demanda para este tipo de produto, as transações via mercado demonstravam ser a estrutura de governança mais eficiente. O custo dessa forma de transação, no entanto, crescia quando aumentava a preocupação com questões relacionadas à qualidade e da moda para a produção das roupas. 


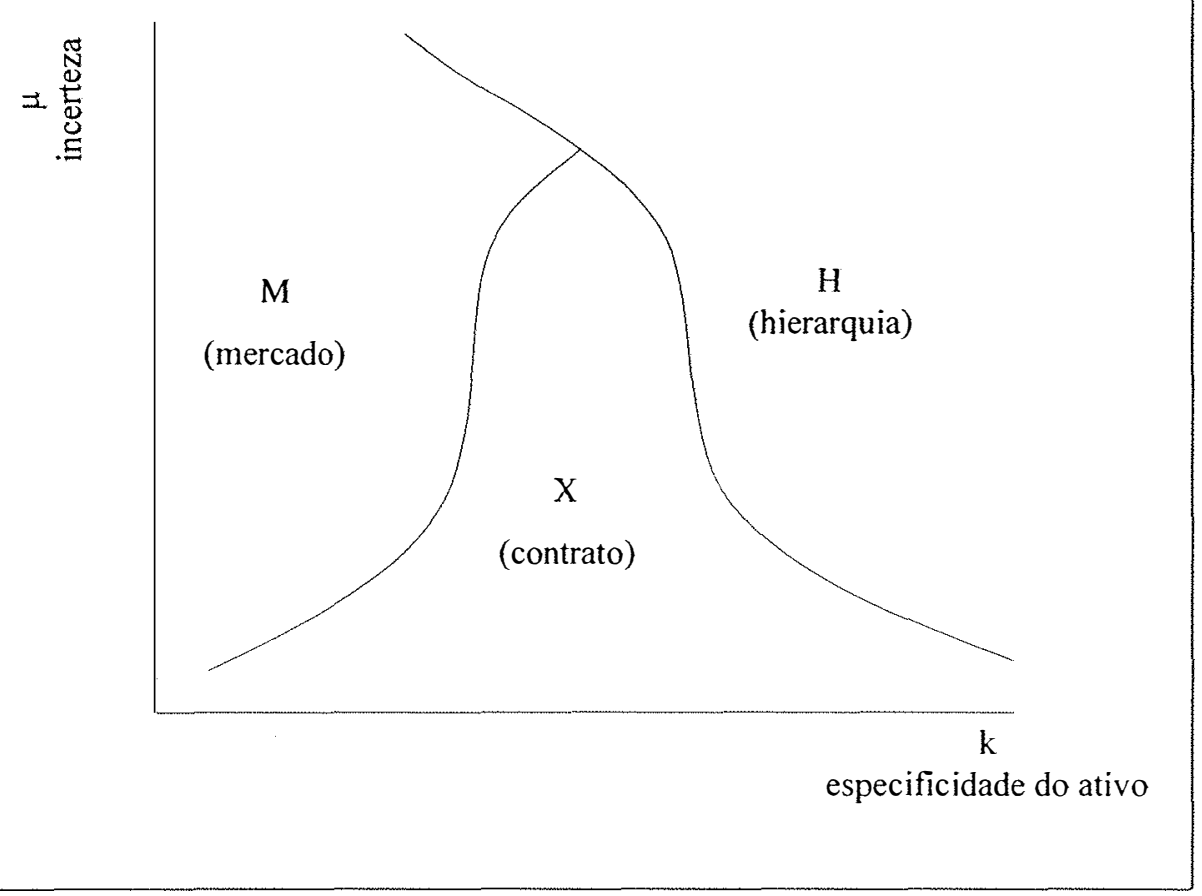

Fonte: Williamson (1991)

Gráfico 2. Formas de respostas das organizações às alterações dos níveis de incerteza e da especificidade dos ativos.

De fato, a política de qualidade e moda requerem adaptações contínuas de produção, necessitando novos desenhos e estilos de roupas, com a redefinição de tipos de componentes e especificações e, consequentemente, elevando o risco das operações via mercado. Há necessidade de se intensificar o controle de qualidade do produto para manter os padrões desejados, sugerindo o estabelecimento de contratos entre as partes. Com 0 aumento da especificidade, os arranjos contratuais vão se tornando mais incertos, necessitando negociações cada vez mais freqüentes. Além disso, este setor é fortemente sensivel a informações confidenciais sobre lançamento de novos produtos e, em muitas situações, requer ativos mais dedicados para se produzir produtos intermediários e finais. Essa situação mais extrema, dada a sua 
incerteza como conseqüência da diferenciação do produto, sugere a verticalização das diversas fases de produção.

Finalmente, deve-se destacar ainda a relação direta entre a incerteza e os custos de produção, sugeridas por Klein et al. (1978). Graus de incerteza muito elevados, em função da especialização, elevam os custos de produção e investimento, já que a possibilidade de uso alternativo de uma ativo específico torna-se muito reduzido.

c) Fregüência: Refere-se à recorrência e/ou regularidade de uma transação. Assim, quanto mais freqüente for uma transação, mais uma estrutura especializada pode se manter, diminuindo seus custos. É importante para a determinação do formato contratual e das estruturas de monitoramento e incentivo dos agentes.

O Quadro 2 apresenta, esquematicamente, como ocorrem essa relações, em função da especificidade do ativo, incorporando o conceito de freqüência das transações.

\begin{tabular}{|c|c|c|c|c|}
\hline \multicolumn{2}{|l|}{} & \multicolumn{3}{c|}{ Ativos } \\
\hline Freqüência & Ocão específicos & mistos & idiossincráticos \\
das & & mercado & contratos & contratos com arbitragem \\
Transações & Freqüentes & mercado & Bilaterais & Integração vertical \\
\hline
\end{tabular}

Fonte: Loader (1997)

Quadro 2. Relação entre as características das transações e as formas de governança esperadas. 
Milgrom \& Roberts (1992, p. 30-33), citados por Machado (2000), acrescentam mais quatro atributos para explicar as transações que, combinados com os três atributos básicos, permitem captar outras dimensões das transações e, em decorrência, identificar os custos de transação e os arranjos contratuais mais adequados:

O primeiro atributo seria a duração da transação: além da freqüência, se a transação tiver uma "duração" mais longa, permite que as partes desenvolvam confiança e mútuo entendimento. A necessidade de mecanismos formais para fazer cumprir acordos é reduzida, economizando custos de transação.

O segundo atributo apontado por aqueles autores relaciona-se com a complexidade da transação, determinante na geração de custos. O terceiro relaciona-se à dificuldade de mensuração do desempenho, que afeta a definição de incentivos e o monitoramento de contratos. Nesse caso, as partes podem preferir organizações onde questões de medida de desempenho são de menor importância.

Finalmente, sugerem a conectividade das transações como outra característica que afeta os custos, principalmente quando envolve muitas pessoas. Quanto maior é a inter-relação entre as transações, mais mecanismos de coordenação são necessários para evitar problemas, seja através de maior supervisão, seja devido a encontros freqüentes entre as pessoas responsáveis por transações individuais. A internalização dessas transações numa única firma reduz os custos de coordenação. Diante de um ambiente mutável, a firma é relativamente mais capaz de se adaptar às mudanças do que o mercado.

Além desses sete atributos centrais mencionados, devem-se, ainda, destacar dois importantes pressupostos comportamentais da teoria da ECT, que terão influência na determinação da estrutura de governança. São eles: 
a) racionalidade limitada dos agentes, já que, além de o fluxo da informação ser imperfeito, diferentes indivíduos apresentam distintas capacidades de absorver e processar toda a informação disponivel, de forma a maximizar seu objetivo;

b) comportamento oportunista, que pode ser definido como "auto-interesse com avidez dos agentes" (Williamson, 1985, p. 47), assumindo que, eventualmente, uma das partes do contrato pode se aproveitar, por exemplo, de uma falha contratual para agir em benefício próprio, prejudicando a outra parte.

Incorporando-se esses pressupostos comportamentais na análise dos contratos, Williamson (1985) relaciona a sua ocorrência e as especificidades do ativo com a forma contratual redutora de custos de transação, conforme modelo apresentado no Quadro 3.

No primeiro caso, na presença de racionalidade total, porém com agentes oportunistas e ativos específicos, sugere-se o planejamento, onde todos os aspectos do contrato podem ser previstos durante a fase de desenho contratual. Os contratos, nessa situação, seriam completos e efetivos, já que os agentes seriam totalmente racionais e poderiam prever todas as situações exante. 


\begin{tabular}{|c|c|c|c|}
\hline \multicolumn{2}{|c|}{ pressupostos comportamentais } & especificidade & Tipo de \\
\hline racionalidade limitada & oportunismo & do ativo & contrato \\
\hline 0 & + & + & $\begin{array}{c}\text { Planejamento (capacidade de } \\
\text { previsão de todos os } \\
\text { problemas potenciais) }\end{array}$ \\
\hline+ & 0 & + & $\begin{array}{c}\text { Promessa (baseado na } \\
\text { honestidade das partes) }\end{array}$ \\
\hline+ & + & 0 & Mercado (competição) \\
\hline+ & + & + & contrato ou integração vertical \\
\hline
\end{tabular}

Obs.: $(+)=$ presente, e $(0)=$ não presente

Fonte: Williamson $(1985$, p. 31)

Quadro 3. Relação entre comportamentos dos indivíduos, especificidade dos ativos e tipo de contrato esperado.

No segundo caso, na ausência de oportunismo, porém com racionalidade limitada dos agentes econômicos e presença de ativos específicos, a simples promessa seria suficiente ${ }^{10}$.

$\mathrm{Na}$ terceira situação, a racionalidade limitada e oportunismo estão presentes, porém os ativos podem ser livremente deslocados entre suas utilizações; o mercado arbitraria as disputas e não haveria interesse da identificação entre as partes.

Finalmente, as três estratégias elencadas não funcionariam em uma situação em que houvesse, simultaneamente, racionalidade limitada, oportunismo e

\footnotetext{
${ }^{10}$ Situações como essa ainda podem ser observadas em pequenas comunidades do interior do País, onde o que prevalece nas negociações é, acima de tudo, a palavra do individuo - considerada como seu mais precioso ativo. A expressão antiga afirma que o "fio do bigode" do individuo vale mais do que sua própria assinatura.
} 
especificidade de ativos. Neste caso, o planejamento seria incompleto (pois a racionalidade é limitada), a promessa não seria necessariamente cumprida (em função do oportunismo) e haveria interesse no conhecimento mútuo entre as partes (pois os ativos são específicos). A esta situação WILIIAMSOM denominou de "o mundo da governança" e as relações contratuais seriam aquelas minimizadoras dos custos envolvidos. No próximo item, pretende-se explorar este modelo, aplicando-o aos Sistemas Agroindustriais.

Finalmente, pode-se concluir este item, citando Zylbersztajn (1995, p. 141), que sintetiza:

"O modelo de governança é uma variável endógena do modelo proposto por Williamson (1985 e 1991), que resulta da busca do prêmio pela escolha do modo de governança minimizador de custos, compatível com as características das transações envolvidas. As variáveis exógenas do modelo são representadas pelas características das transações e pelo ambiente institucional, ambos condicionados pelos pressupostos comportamentais, como a racionalidade limitada e o oportunismo."

\subsection{Alterações nos atributos e estrutura de governança dos SAGs}

Loader (1997), baseado em Williamson (1985) apresenta uma descrição sistematizada das implicações dos atributos das transações em relação às estruturas de governanças.

- Se a especificidade do ativo é alta, a transação via mercado é improvável.

- Se a racionalidade limitada está presente, as quebras contratuais podem ocorrer, pois não se pode delinear um contrato com todas as considerações ex ante, aumentando a incerteza e a necessidade de maior coordenação. 
- Se o oportunismo está presente, regras de incentivo e controle no relacionamento entre os agentes devem ser desenhadas.

- Se as transações são freqüentes, espera-se uma relação entre os agentes com alguma forma regular de governança.

- Se a transação apresenta comportamento incerto, há necessidade de estabilizar a relação com maior grau de coordenação vertical.

A partir dessa sistematização - que envolve a especificidade do ativo, freqüência e incerteza -, pretende-se analisar o mercado de grãos, enfocando as relações entre produtores e compradores (agroindústria e/ou tradings), sob duas óticas distintas: i) o mercado de commodities de grãos; e ii) o mercado de grãos com atributos diferenciados em que há a necessidade de preservação de sua identidade $(\mathrm{PI})$.

\subsubsection{Formas de governança no mercado de commodities}

Historicamente, os grãos caracterizam-se como commodities e, como tal, são negociados: por meio de transações via mercado, dado um determinado ambiente institucional e organizacional. A Figura 4 apresenta um exemplo desse fluxograma tradicional, destacando-se os principais agentes do SAG do milho, inserido no seu ambiente institucional. Padrões relativamente simples, como níveis mínimos de impureza e umidade, são suficientes para o atendimento das necessidades requeridas, indicando um baixo nível de especificidade dedicada. As especificidades temporal, locacional e humana também são baixas, visto que, respectivamente: i) a perecibilidade de produtos como soja ou milho é baixa, podendo ficar armazenados por vários meses ou, em condições adequadas, até mesmo, anos. Além disso, a possibilidade de importação de outros países, nos períodos de entressafra brasileira, também 
reduz a especificidade temporal do ativo; ii) quanto à especificidade locacional, apesar de a proximidade ser desejável (dado o seu baixo valor específico), em muitos casos, os grãos são transportados por longas distâncias, intra e inter países ${ }^{11}$; iii) em relação à especificidade humana, apesar do rápido processo de tecnificação da atividade agrícola, de um modo geral, não se verifica um aumento correspondente da especialização da mão-de-obra no setor.

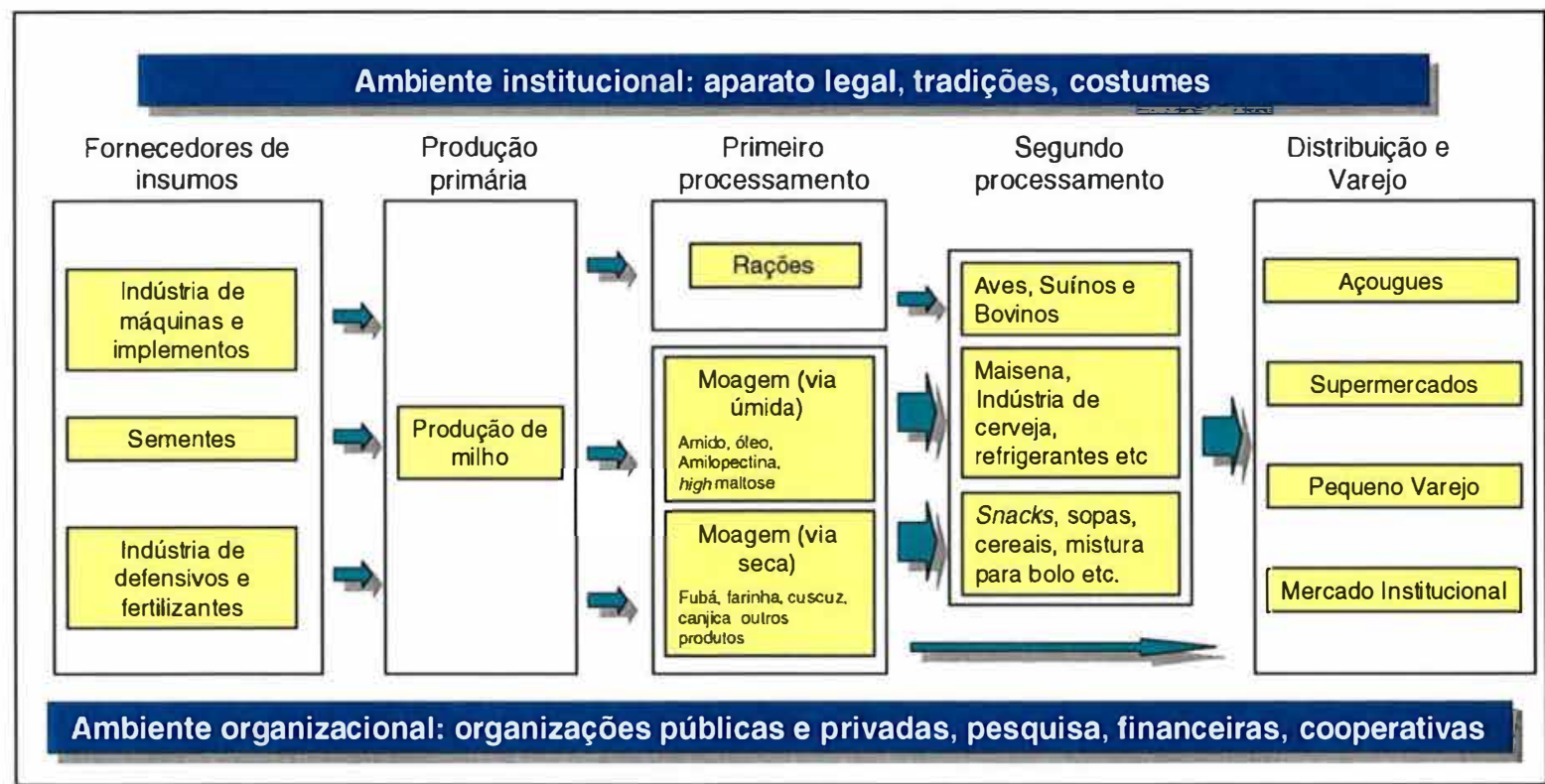

Fonte: elaborado pelo autor

Figura 4. Fluxograma do Sistema Agroindustrial do milho.

A freqüência das transações também é baixa, visto que a maior parte dos produtores já comercializam sua safra nos meses subseqüentes à colheita desses produtos, sendo que muito poucos o fazem de forma parcelada. $O$ grau de incerteza não é desprezível, estando fortemente relacionado com os riscos da própria atividade agrícola, como intempéries e ocorrência de pragas e doenças. Essa incerteza, no entanto, pode ser minimizada com a opção pelo seguro rural.

\footnotetext{
${ }^{11}$ Segundo o GEIPOT (1997), as distâncias rodoviárias médias percorridas no Brasil chegam a atingir mais de $1.500 \mathrm{~km}$ para os casos do milho e do arroz e cerca de $750 \mathrm{~km}$, no caso da soja.
} 
Deve-se, ainda, considerar os pressupostos comportamentais: oportunismo e grau de racionalidade. Quanto à possibilidade de oportunismo, considera-se que seja baixa: dada a baixa especificidade do ativo e a estrutura relativamente competitiva do mercado, produtores e agroindústria têm a oportunidade de escolha de compradores ou vendedores. Além disso, alguns fatores, como a maior inserção brasileira no mercado internacional, o fortalecimento das Bolsas de Futuros e o desenvolvimento de novos instrumentos de comercialização muitos dos quais negociados em bolsas eletrônicas - têm permitido a maior fluidez da informação nos mercados agrícolas ${ }^{12}$. Como conseqüência, verificase o aumento da transparência dos mercados de grãos no País e a menor possibilidade de oportunismo por parte de produtores e compradores.

Pode-se constatar, também, a racionalidade limitada dos agentes, presente nesses mercados devido, principalmente, às incertezas associadas aos riscos de produção e de preços na época da venda ${ }^{13}$.

O Quadro 4 procura sistematizar essa avaliação, relacionando as características da transação de commodities com a estrutura de governança esperada - economizadora de custos de transação - envolvendo produtores e empresas consumidoras de grãos, segundo o modelo sugerido por Loader. Verifica-se o predomínio da estrutura esperada via mercado.

\footnotetext{
${ }^{12}$ Para maiores informações sobre novos mecanismos de comercialização, sugere-se Marques \& Sousa (1998).

${ }^{13}$ Como já destacado, no entanto, ambos os riscos podem ser amenizados - por meio de seguro agrícola e de Bolsas de Futuros, ainda que com imperfeições.
} 
Objeto da transação grãos commodities estrutura esperada

\section{Atributo da transação}

1. Especificidade do ativo:

\begin{tabular}{lcc} 
física & + & $\mathrm{M}$ \\
temporal & + & $\mathrm{M}$ \\
locacional & + & $\mathrm{M}$ \\
humana & + & $\mathrm{M}$ \\
2. Freqüência & + & $\mathrm{M}$ \\
3. Incerteza & + & $\mathrm{M} / \mathrm{C}$ \\
$\begin{array}{l}\text { Pressupostos } \\
\text { comportamentais }\end{array}$ & \\
$\begin{array}{l}\text { 1. Oportunismo } \\
\text { 2. Racionalidade limitada }\end{array}$ & $\mathrm{M}$ \\
\hline Avaliação geral & ++ & $\mathrm{M} / \mathrm{C}$ \\
\hline
\end{tabular}

\section{Legenda:}
$(+)=$ baixo;
$++)=$ médio, $\mathrm{e} \quad(+++)=$ alto
$\mathrm{M}=$ mercado; $\mathrm{C}=$ contratos

Fonte: Adaptado de Loader (1997)

Quadro 4. Estrutura de governança esperada entre produtores e agroindústria, em função dos atributos das transações com produtos commodities.

\subsubsection{Formas de governança no mercado de produtos diferenciados}

Pretende-se, agora, avaliar um cenário em que há diferenciação dos atributos dos produtos e conseqüente elevação da especificidade dos ativos. A teoria sugere uma estrutura de governança diferente do primeiro caso, mais próxima 
da forma híbrida, que minimize os custos de transação. Basicamente, as alterações previstas nas características das transações seriam as seguintes:

a) aumento da especificidade do ativo: o grão produzido passa a ter utilização mais específica, deixando de agregar valor se não for empregado para a utilização prevista (ex.: milho com maior teor de óleo). Aumento, também, da especificidade locacional e temporal, visto que as indústrias vão preferir, respectivamente: i) incentivar a produção perto de suas plantas (permitindo maior monitoramento do plantio e, se necessário, de tratos culturais) ii) garantir o suprimento da mercadoria, logo após a safra, sob pena de não consegui-la no mercado. Em alguns casos, deve haver, também, um aumento da especificidade humana, visto que demandará uma maior capacitação tecnológica (ex: produção dos chamados "cafés especiais")

b) aumento da incerteza e oportunismo, já que passa a haver uma maior dependência de ambas as partes em função do aumento da especificidade do ativo. De fato, Farina \& Zylbersztajn (1991) afirmam que, quanto maior importância for atribuída a características específicas do alimento, e quanto mais essas características estiverem associadas à matéria-prima e não ao processamento industrial, maior será a "exposição" da agroindústria ao comportamento de seus fornecedores. Ou seja, espera-se que, quanto maior a especificidade dos atributos da matéria-prima, maior seja a necessidade de estabelecimento de comprometimento entre produtor rural e agroindústria.

Seguindo, ainda, a sistematização proposta por Loader (1997), o Quadro 5 apresenta as características das transações entre os segmentos da produção rural e da agroindústria, na presença de atributos diferenciados. As relações via contrato são as que minimizam os custos de transação. 


\begin{tabular}{lcc}
\hline Objeto da transação & $\begin{array}{c}\text { Grãos com atributos } \\
\text { diferenciados }\end{array}$ & estrutura esperada \\
\hline
\end{tabular}

\section{Atributo da transação}

1. Especificidade do ativo:

\begin{tabular}{lcc} 
fisica & +++ & $\mathrm{C}$ \\
temporal & +++ & $\mathrm{C}$ \\
locacional & +++ & $\mathrm{C}$ \\
humana & ++ & $\mathrm{C} / \mathrm{M}$ \\
2. Freqüencia & + & $\mathrm{M}$ \\
3. Incerteza & +++ & $\mathrm{C}$ \\
$\begin{array}{l}\text { Pressupostos } \\
\text { comportamentais }\end{array}$ & \\
$\begin{array}{l}\text { 1. Oportunismo } \\
\text { 2. Racionalidade limitada }\end{array}$ & +++ & $\mathrm{C}$ \\
\hline
\end{tabular}

Estrutura esperada

C

Legenda:

$(+)=$ baixo; $\quad(++)=$ médio, e $\quad(+++)=$ alto

$\mathrm{M}=$ mercado; $\mathrm{C}=$ contratos

Fonte: Adaptado de Loader (1997)

Quadro 5. Estrutura de governança esperada entre produtores e agroindústria, em função dos atributos das transações com produtos commodities. 


\subsection{Sub-sistemas estritamente coordenados}

Outro conceito fundamental para o presente trabalho é o de sub-sistemas estritamente coordenados, apresentado por Zylbersztajn \& Farina (1997) como "uma seqüência de transações envolvendo ativos de maior especificidade, associados a um determinado grupo de empresas seguindo objetivos comuns". Farina \& Zylbersztajn (1997) vinculam este conceito à estratégia do SAG como um todo, trazendo o conceito de Sub-sistema Agroindustrial - sub-SAG estratégico definido por estruturas de governança distintas do SAG genérico.

A formação desses sub-sistemas pode ser iniciada pela estratégia bem sucedida de uma firma individual que coordena um sistema próprio, por meio de contratos formais ou informais. O processo de imitação das estratégias bem sucedidas pode resultar em um conjunto de firmas que disputam o mesmo segmento e compartilham o mesmo padrão de concorrência. A esse conjunto de empresas dá-se o nome de grupo estratégico.

Assim, transformações nos atributos das transações poderão impactar o nivel de especificidade dos ativos envolvidos, aumentando a ocorrência de adaptações induzidas que, por sua vez, poderão delinear SAGs estritamente coordenados. Se tal mudança resultar em padrão para um determinado grupo de empresas dentro do SAG, passa a ocorrer um sub-SAG estratégico. Deve-se destacar, no entanto, que um grupo estratégico resultará em sub-sistema se, e somente se, implicar uma nova estrutura de governança.

No caso dos Sistemas Agroindustriais, espera-se que o aumento da especificidade dos ativos induza à formação de sub-grupos coordenados, de forma a garantir a manutenção da qualidade e dos atributos desejados. O papel de coordenação poderá ser exercido pelos segmentos mais organizados do sistema. A partir da sinalização de preferências do consumidor, ou do desenvolvimento de novos processos industriais, a indústria passa a demandar um produto específico. Essa demanda é repassada à indústria de sementes, 
que procura desenvolver produtos que se adeqüem aos padrões requeridos. Os produtores deverão, então, receber incentivos para utilizar as sementes com os atributos diferenciados (o que pode ser via preços, adiantamento de insumos ou compartilhamento de riscos, por exemplo) e, para tanto, deverão ser monitorados, seja pela indústria, seja por agentes certificadores - para que mantenham, efetivamente, o padrão estabelecido em contratos.

Assim, pode-se supor a coexistência de duas ou mais distintas estruturas de governança dentro de um mesmo SAG, conforme os atributos e especificidades dos ativos envolvidos, divididas da seguinte forma:

1) Mercado, como a forma economizadora de custos para o fluxo do produto ao longo do SAG nos sistemas sem atributos diferenciados específicos. Nesse caso, o fluxo de informação relevante para o desenvolvimento de sementes parte, principalmente, dos produtores, que sinalizam os atributos agronômicos que permitem maiores produtividades ou menores custos de produção.

2) Sub-SAG's estritamente coordenados, com estabelecimento de contratos (formais ou informais) ao longo da cadeia, para produtos com elevada especificidade. O fluxo de informação parte, principalmente, do consumidor para os atacadistas e processadores. Esses últimos, em muitas situações, exercem um papel relevante no processo de coordenação a jusante e a montante, o que thes confere uma visão global. Sinalizam aos produtores de sementes os atributos qualitativos desejados, geram incentivos e formas de controle aos produtores rurais e desenvolvem estratégias a fim de manter essas características até os consumidores finais. Deve-se ressaltar, no entanto, que qualquer um dos atores do sistema pode desempenhar esse papel. A Figura 5 apresenta um fluxograma ilustrativo de um sub-sistema estritamente coordenado. 


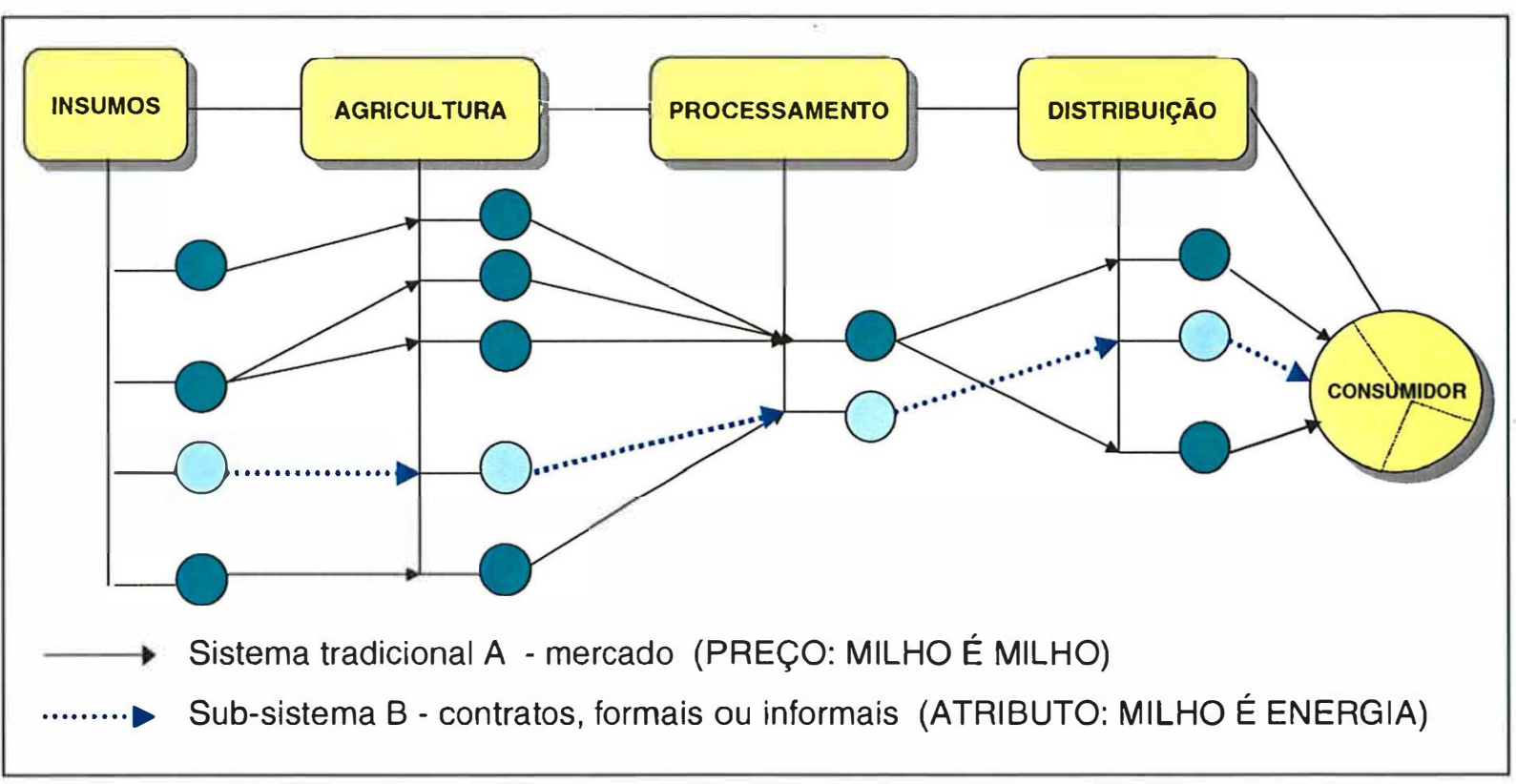

Fonte: Adaptado de Zylbersztajn \& Farina (1999)

Figura 5. Estrutura de sub-sistema vertical estritamente coordenado.

Em algumas situações, os arranjos contratuais podem oferecer uma coordenação superior (em eficiência) e, dessa forma, se expandir para outros agentes do SAG. Zylbersztajn \& Farina (1999) sugerem que a taxa de difusão de sub-sistema dependerá, então, de alguns dos seguintes aspectos:

- resposta do consumidor aos atributos específicos associados ao sub-SAG, que poderá gerar novos padrões de consumo, alterando o padrão competitivo;

- custos de monitoramento associados às transações;

- ambiente institucional, provendo padrões e controles;

- mecanismos internos de controle para resolver disputas, em relação aos efeitos distributivos ou adaptações contratuais. 
Os autores concluem que a dinâmica dos sub-SAGs, embora ainda não totalmente compreendida, está, necessariamente, associada ao gerenciamento da cadeia produtiva, e particularmente vinculada à abordagem de coordenação vertical de Williamson.

Em alguns SAGs no Brasil, já se verifica a existência desses sub-sistemas estritamente coordenados, em que a ocorrência de ativos altamente especializados exigiu o estabelecimento de estratégias de suprimento e distribuição diferenciados dentro do sistema, de forma a garantir a qualidade desejada. As diferentes formas de estímulo e controle desenvolvidas serão analisadas nos estudos empíricos do capítulo cinco.

\subsection{Contratos na agricultura}

Esta última parte pretende apresentar algumas considerações a respeito das formas de contrato no setor agrícola, destacando algumas estatísticas relacionadas à evolução desta forma de governança nos Estados Unidos, país que já conta com marcante tradição nesse setor.

A maior preocupação do consumidor com atributos de qualidade e as inovações tecnológicas têm-se constituído em fatores fundamentais para a consolidação do processo de maior nível de comprometimento entre os elos da cadeia alimentar. De fato, observa-se uma crescente incorporação de novos produtos agrícolas ao sistema contratual. Pesquisa realizada pelo USDA, citada por Dimitri \& Jaecnicke (2000), aponta que, em 1997, quase $33 \%$ do valor de todos os produtos agrícolas e pecuários já eram produzidos ou comercializados, sob contratos. Comparativamente, os contratos afetavam apenas $11 \%$ de todos os produtos em 1993. Esses autores sustentam que esse deslocamento do mercado para o sistema de contratos (hierárquico) para tantos produtos surge 
como uma resposta às mudanças dos processos de transformação e, consequentemente, altera os custos de transação.

Ainda segundo essa pesquisa, em 1997, eram produzidos sob a forma contratual: $70 \%$ da produção de aves, $33 \%$, da de suínos e $14 \%$ da produção bovina. No caso de produtos agrícolas, os números eram, na média, um pouco inferiores aos do setor pecuário, porém significativos: $22 \%$ de todos os produtos agrícolas dependiam de contrato, distribuídos da seguinte forma: $40 \%$, no caso de frutas frescas e vegetais, $33 \%$ do algodão, $8 \%$ da soja e $82 \%$ do açúcar de beterraba.

Como principais benefícios decorrentes do estabelecimento de contratos na agricultura, podem-se citar, entre outros:

- garantia de compra (em relação à quantidade e qualidade);

- garantia de preços;

- financiamentos, via insumos ou adiantamento de recursos;

- investimentos conjuntos (parcerias);

- pagamento de prêmios por qualidade,

- fornecedor preferencial, mas não exclusivo.

Mighell \& Jones (1963) sugerem a divisão dos contratos de comercialização em três grupos:

a) Contrato com especificação de qualidade que representa o compromisso (de um comprador) de adquirir uma determinada quantidade de um produto (de um produtor). O comprador pode assumir algum risco e o direito de tomar decisões quanto à época do pagamento. O produtor continua com 
controle sobre as práticas de produção. Esse é um caso muito freqüente, nos contratos entre produtores e compradores de grãos commodities.

b) Contrato de gerenciamento da produção, que amplia o controle do comprador, permitindo que ele especifique e monitore as práticas produtivas, utilização de insumos etc. Observa-se essa situação, com freqüência, nos contratos entre produtores de hortigranjeiros e grande redes varejistas.

c) Contrato de fornecimento de recursos, que representa o maior nível de controle do comprador, que provê a aquisição do produto, supervisiona as práticas produtivas e fornece os insumos chaves. Com isso, o comprador, usualmente, assume uma maior proporção do risco. É o caso das integrações de aves.

Essa divisão, no entanto, pode contemplar diversas combinações de variáveis, com diferentes impactos sobre a distribuição de riscos e de propriedade dos produtos e bens de capital entre as partes envolvidas. Verifica-se, também, que, além de benefícios, como menores riscos associados a preços e à comercialização ou provimento de alavancagem financeira, o estabelecimento de contratos pode trazer algum ônus às partes. Assim, o produtor pode deixar de se beneficiar com altas de preços, quando já fixou seu preço de venda antes do início da safra. Em outras situações, necessita fazer investimentos depreciáveis em vários anos, para atender a uma determinada demanda, mas os contratos contemplam, apenas, o período de uma safra. Da mesma forma, tanto contratados quanto contratantes incorrem em custos relacionados ao monitoramento de quantidade e qualidade, para atender às exigências do contratos. O Quadro 6 enumera algumas dessas vantagens e desvantagens para os produtores rurais, no caso de contratos envolvendo a produção e venda de produtos diferenciados. 


\begin{tabular}{|c|c|}
\hline Vantagens do contrato & Desvantagens do contrato \\
\hline Prêmios ao preço & $\begin{array}{l}\text { Possibilidade de perda do controle do } \\
\text { produtor e flexibilidade reduzida }\end{array}$ \\
\hline Acesso a novas tecnologias & $\begin{array}{l}\text { Possibilidade de queda na produtividade } \\
\text { na produção de especialidades }\end{array}$ \\
\hline Disponibilidade do mercado & Risco de não ser pago \\
\hline Redução no risco de financiamento & $\begin{array}{l}\text { Investimento de longo prazo/contratos de } \\
\text { curto prazo }\end{array}$ \\
\hline Redução no risco de mercado & Retornos limitados (ao produtor) \\
\hline Preservação de identidade & Preservação de identidade \\
\hline
\end{tabular}

Fonte: Cullman Jackson (1999), in Hahn et al. (2000)

Quadro 6. Aspectos positivos e negativos na contratação de produtos diferenciados ao produtor.

A fim de minimizar os riscos do contrato, Cordier (2000) sugere a existência de, pelo menos quatro mecanismos como parte integrante do contrato: i) o estabelecimento das regras básicas, que se definem claramente os benefícios e perdas de cada uma das partes envolvidas, além dos parâmetros que irão balizar essas perdas ou ganhos; ii) a definição clara da parte responsável para gerenciar as situações não previstas nas regras básicas e a indicação de um árbitro para dirimir impasses, no qual as partes envolvidas tenham confiança, quando necessário; iii) um sistema de controle que possa garantir o desenvolvimento do contrato de forma eficiente, em sintonia com os esforços mútuos requeridos; e iv) incentivos suficientes que dêem suporte ao sistema de controle e diminua o potencial de comportamentos oportunísticos das partes. 
Este capítulo discutiu a necessidade de arranjos contratuais, envolvendo a PI de produtos diferenciados, tendo, como objetivo final, a redução de custos de transação. Mostrou, também, que essas formas de coordenação podem ocorrer como um sub-conjunto de relações contratuais dentro de um SAG genérico. Finalmente, analisou características relacionadas aos contratos na agricultura, destacando estatísticas relacionadas à evolução desse processo nos EUA. As características das transações e os mecanismos de coordenação de sistemas e sub-sistemas agroindustriais serão objeto de análise do próximo capítulo. 
3 CARACTERISTICAS DAS

TRANSAÇÕES E A COORDENAÇÃO DOS SISTEMAS AGROINDUSTRIAIS 


\section{CARACTERÍSTICAS DAS TRANSAÇÕES E COORDENAÇÃO DOS SISTEMAS AGROINDUSTRIAIS}

"A qualidade pode ser definida e mensurável, mas é irrecuperável quando perdida em qualquer ponto da cadeia produtiva" (Flavio Lazzari, especialista em qualidade de produtos agroalimentares)

Neste capitulo, será avaliado o processo de coordenação, a partir de algumas características das transações. O que se pretende é identificar os atributos relevantes para a determinação da estrutura de governança mais eficiente para a Pl de grãos com atributos diferenciados.

Segundo Zylbersztajn (1995, p. 131), a coordenação de sistemas de agribusiness é definida como "o resultado da ação de distintos mecanismos que permitem suprir as necessidades dos consumidores finais". O autor sugere que "tal definição é suficientemente ampla para englobar a coordenação via mecanismo de preços, nos casos onde os mercados operam sem distorções e onde os custos de transação forem iguais a zero. Outrossim, permite a inserção de mecanismos contratuais e aspectos institucionais desenhados para darem suporte ao funcionamento e coordenação do sistema". A coordenação está fortemente vinculada à capacidade gerencial (ou a capacidade de intervir) dentro do SAG e implica a motivação (ex-ante) e o monitoramento (ex-post). 
Nesse sentido, como já discutido no capítulo anterior, a simples sinalização de um preço diferenciado pode não ser suficiente para estimular o empresário rural a produzir um produto com atributos especificos, dadas as incertezas da negociação, possibilidades de oportunismo das empresas adquirentes e os possiveis investimentos em ativos com elevada especificidade.

Contratos entre as partes podem diminuir os custos associados a essas transações, mas também, dependendo das características, podem não ser suficientes para garantir a manutenção da qualidade requerida pelo consumidor final. Em algumas situações, pode-se demandar a contratação de terceiras partes, como, por exemplo, empresas certificadoras, ou haver a necessidade de normas e padrões rígidos impostos pelo Estado.

Assim, a provisão de bens públicos e coletivos é também relevante para o desenvolvimento das estratégias das empresas e sua competitividade. A oferta adequada desses bens depende da ação do Estado ou de organizações de interesse privado, - tais como associações de produtores, sindicatos etc.

Nos próximos itens, serão descritas algumas caraterísticas selecionadas das transações - associadas aos seus custos - consideradas relevantes para a preservação da identidade de grãos. Para tanto, será utilizado o referencial teórico apresentado no capítulo 2 e a sistematização das variáveis de custos de transação proposta por Hobbs (1996) e Hobbs (1997), da seguinte forma: no item 3.1, serão discutidas características relacionadas aos custos de informação, como formação de preços e busca de parceiros; no item, 3.2, os custos da negociação física, relacionada ao mercado físico da transação; finalmente, no item 3.3 , os conceitos de certificação e rastreabilidade, instrumentos fundamentais para o processo de coordenação em condições de 
assimetria informacional ${ }^{14}$, que representa o terceiro grupo de custos de transação, os custos de monitoramento.

\subsection{Custos da informação}

Segundo a sistematização proposta por Hobbs (1996), os custos da informação surgem antes de ocorrer a transação e estão associados, principalmente, àqueles incorridos pelos agentes na busca de produtos, de compradores ou vendedores e na formação de preços. Um exemplo seria o dos custos que os criadores de gado incorrem para definir o preço de um determinado lote. A existência de leilões permite que os preços sejam fixados pelo processo de ofertas competitivas entre compradores, reduzindo consideravelmente o custo da obtenção das cotações. A partir daí, os preços negociados tornam-se públicos e disponiveis a todos os agentes e podem balizar as demais transações a posteriori e nas regiões adjacentes ao leilão.

Para produtos considerados commodities, as bolsas de mercadorias agropecuárias, no mercado físico, constituem importante redutor de custos de transações para os agentes, já que permitem a confluência de demandantes e ofertantes de um determinado produto, ao mesmo tempo que conferem transparência e visibilidade para a formação de preços. Da mesma forma, as bolsas de futuros permitem uma sinalização de preços no futuro e o gerenciamento de risco da atividade, diminuindo a incerteza entre os participantes do mercado. Assim, dentre outros fatores, quanto maior a facilidade de padronização e mais pulverizado for o mercado comprador e vendedor, maior a possibilidade de liquidez nesses mercados (Sousa, 1996).

\footnotetext{
${ }^{14} \mathrm{~A}$ assimetria informacional refere-se à incapacidade de o consumidor perceber a maior parte das qualidades intrínsecas dos produtos e abre espaço para ações oportunísticas. O exemplo clássico é o do comércio de carros usados no qual "o vendedor tem a informação sobre a real condição do veículo, enquanto o comprador tem custos não despreziveis para verificar essa condição". Milgrom \& Roberts (1992) argumentam que a informação sempre tem custos, é assimétrica e imperfeita.
} 
Com a maior diferenciação dos produtos, a tecnologia da informação também tem exercido uma influência cada vez mais expressiva na organização estrutural dos negócios. Machado (1998:71) define a tecnologia da informação como "o complexo tecnológico que conjuga computadores, softwares, redes de comunicação eletrônica pública e privada, tecnologias de telecomunicações, protocolos de transmissão de dados bem como os serviços de comunicação de dados e softwares aplicativos e outros serviços". A autora, citando Streeter et al. (1991) sugere que a coordenação da cadeia alimentar aumente pela maior capacidade da tecnologia da informação apreender, na ponta da cadeia, os desejos dos consumidores e transferir essas informações para os agentes a montante da cadeia. Esse processo torna-se ainda mais relevante com a maior demanda por produtos mais diferenciados, segundo atributos mais específicos.

Segundo Hayenga \& Kalaitzandonakes (1999), significativos investimentos em sistemas de informação têm sido realizados nos EUA, para a criação de mercados virtuais e sistemas de gerenciamento apropriados para a cadeia produtiva de produtos com identidade preservada. Sonka (1999a) afirma que a coordenação de mercados, via comunicação eletrônica, terá um papel significativo na administração de elementos intangíveis, incluindo ações como:

- Construção de vínculos de informação e relacionamento ao longo da cadeia produtiva;

- incremento da capacidade de administrar a informação;

- teste de sistemas de produção alternativos antes que a eficácia de tais sistemas seja largamente conhecida;

- monitoramento do desenvolvimento econômico e mercadológico ao longo da cadeia produtiva.

Sonka (1999b) sugere que, para o consumidor, os benefícios da tecnologia de 
informação (TI) estão fortemente associados ao processo de diminuição dos seus custos, que deverá ocorrer simultaneamente com a sua maior difusão.

Além dos benefícios associados ao sistema produtivo agrícola (como a biotecnologia - resultado da informação genética - e a agricultura de precisão ${ }^{15}$ ) podem-se destacar duas formas de TI que irão impactar diretamente a eficiência sistêmica dos SAGs de grãos: i) tecnologias de aparelhos de medição para análises da composição física e química dos produtos (que será discutida no item 3.3., sobre a intangibilidade de determinados atributos); ii) a comunicação eletrônica via Internet. A Internet tem gerado significativos impactos na comunicação da sociedade em geral e as mesmas tecnologias podem ser - e já estão sendo - utilizadas para a promoção de comunicação no sistema de mercado agrícola (Sonka \& Coaldrake, 1996).

A atividade agrícola é, geralmente, marcada pelas grandes distâncias espaciais. Nesse sentido, a Internet pode representar um importante redutor de custos de transação para o processo de localização e seleção de produtores para empresas que pretendem estabelecer contratos envolvendo preservação de identidade de produtos. A importância desse mecanismo está diretamente associada à maior difusão do uso do computador e da Internet em estabelecimentos rurais, o que já é uma realidade no cenário norte americano. De fato, Villela (2000), citando relatório divulgado pelo USDA, afirma que $47 \%$ do total das fazendas dos EUA já tinham acesso a computadores em 1999 e que $29 \%$ das propriedades estavam conectadas à Internet, mais do que o dobro de 1997 , quando apenas $13 \%$ tinham acesso à rede mundial.

Essa situação tem permitido o sucesso de algumas experiências de utilização da Internet nos EUA, na busca e seleção de produtores. Como exemplo, podem-se citar os contratos de produção e comercialização divulgados e

\footnotetext{
${ }^{15}$ Pierce \& Sandler (1997) descrevem a "agricultura de precisão" como todo o processo tecnológico focado na captura e análise da informação associada à produção agrícola.
} 
firmados pela rede, por meio do sistema denominado OSCAR (Optimum Sales Connection and Resource), desenvolvido a partir do programa Optimum Quality Grains. Esse programa resultou da associação das empresas Du Pont e Pioneer e estabelece uma rede de empresas para comercialização de produtos diferenciados, como o milho com alto teor de óleo. Por meio de seu site (www.optimumqualitygrains.com), as empresas podem localizar produtores nas regiões de seu interesse, indicar fornecedores e locais de entrega e, até mesmo, firmar contratos de cooperação com os produtores rurais. Tudo isso, a um custo de transação bastante inferior àqueles tradicionalmente praticados. Discussão mais aprofundada sobre este caso será desenvolvida no capítulo cinco deste trabalho.

\subsection{Custos da negociação}

Os custos da negociação envolvem aqueles que surgem do ato da negociação física e da forma pela qual ela é conduzida. Hobbs (1996) cita o exemplo do transporte do gado da fazenda para o abatedouro. Esse ato é sempre necessário e não pode, na visão da autora, ser considerado um custo da transação. No entanto, quando há a necessidade de se agregar algum mecanismo para facilitar uma transação específica, como um suporte adicional que permita a movimentação de animais de e para o recinto de um leilão, esse custo extra é considerado um custo de negociação, vinculado àquela transação de venda de gado via leilão. Assim, só serão considerados os custos associados à necessidade da Preservação de Identidade.

Para efeito do presente estudo, os custos de negociação serão divididos em i) custos de reconversão produtivas e ii) custos decorrentes do desenho do contrato. 


\subsubsection{Custos de reconversão e de operacionalização produtiva do sistema de PI}

Este item irá discutir os custos que decorrem das alterações tecnológicas e investimentos em ativos dedicados relacionados ao processo ${ }^{16}$, assim como aqueles relacionados à operacionalização do sistema. Esses custos adicionais permeiam todas as fases da cadeia produtiva, em proporções variáveis, conforme a característica que se deseja preservar. Estão relacionados ao plantio, manejo, armazenagem, transporte, processamento e distribuição e são fundamentais na determinação da competitividade do sistema. Segundo Farina (1996), a competitividade de sistemas depende, em algumas situações, mais da velocidade do seu ajustamento do que, propriamente, da existência de custos de produção menores. Ou seja, o sistema que consegue diminuir mais rapidamente os custos de transação é mais competitivo que outro que tem custos de produção menor, mas custos de transação maiores.

Serão apresentados os principais custos relacionados à PI, para cada uma das seguintes fases: produção agrícola, armazenagem, transporte e processamento industrial.

i) custos adicionais na produção agrícola:

O primeiro incremento nos custos já se inicia, em muitas situações, no processo de produção da semente. O rigor da análise do produto final irá condicionar o grau de preocupação no que tange ao nível de pureza da semente comercializada e, consequentemente, os custos associados a essa tarefa. Um exemplo ilustrativo refere-se aos produtos GM. Para o caso da

\footnotetext{
${ }^{16}$ Esses custos terão maior impacto na decisão dos agentes (e no grau de necessidade de incentivos) quanto maior a especificidade desses ativos. Relacionam-se com o conceito de sunk costs, ou custos não recuperáveis quando a empresa decide sair do mercado. Pode-se citar, como exemplo, gastos com promoção e publicidade ou em ativos muito dedicados.
} 
semente de soja, os padrões de pureza varietal na União Européia (UE) exigem um mínimo de pureza de $95 \%$, o que significa que se admitiria até $5 \%$ de outras variedades, incluindo aí, supostamente, sementes de OGM. O problema é que esta especificação gera um conflito com o grau de tolerância adotado para produtos livres de OGM, inferior a 1\%, em vários países.

Na produção de grãos, Bucckwell et al. (1998) sugerem as seguintes fontes potenciais de contaminação de grãos: i) mistura da semente utilizada pelo produtor rural; ii) mistura com outras variedades, cujas sementes já estavam presentes no solo, na colheita; iii) mistura mecânica no plantio, colheita e armazenagem, e iv) polinização cruzada com outras variedades, a qual varia com a distância, compatibilidade sexual entre plantas e métodos de transporte de pólen, como vento e insetos.

Essas preocupações implicam custos relacionados aos cuidados extras de tratos culturais, à limpeza de máquinas e equipamentos e às eventuais perdas de área física de plantio para evitar problemas de cruzamento de variedades. Além desses, podem-se sugerir ainda, outros custos associados à produção de produtos diferenciados. A reconversão para a produção de soja orgânica, por exemplo, envolve investimentos específicos, como capacitação de pessoal, adaptação de alguns implementos e, até mesmo, aumentos do custo de produção, devido à obrigatoriedade de utilização de fertilizantes de baixa solubilidade para a produção de cereais orgânicos (sugerindo diminuição da produtividade no curto prazo) e de variedades menos produtivas, porém mais adequadas à produção e consumo de soja orgânica.

ii) custos adicionais na armazenagem:

Do ponto de vista da armazenagem, algumas vezes, surge a necessidade de se adaptar as instalações e formas de acondicionamento dos grãos que, via de 
regra, são armazenados a granel. Uma situação provável é a necessidade de se segregar, pelo menos, quatro tipos de grãos: soja e milho commodity e soja e milho diferenciados, implicando investimentos na estrutura e maiores custos operacionais e administrativos no recebimento e expedição desses produtos. Krueger et al. (2000), fazendo simulações a partir de custos, quantidades e intervalos de tempo ${ }^{17}$ históricos nos armazéns de Indiana-EUA, constataram uma sensivel queda na eficiência (custo por caminhão e tempo para descarregamento) na medida em que se introduziam produtos diferenciados ao processo de recebimento. Por outro lado, a agilidade e a eficiência, principalmente no recebimento do produto no período de safra, são consideradas fundamentais para um resultado financeiro satisfatório da atividade armazenadora.

Essa preocupação já é uma realidade para os agentes dos mercados de grãos em alguns países. Segundo pesquisa apresentada por Hayenga \& Kalaitzandonakes (1999), os elevators ${ }^{18}$ americanos esperavam que, até o ano de $2004,25 \%$ de todo o seu movimento viria de culturas com diferenciação de qualidade e, portanto, estavam programando ou efetuando investimentos relevantes na armazenagem adequada para produtos com identidade preservada.

Bender et al. (1999), utilizando uma amostra de 24 elevators e 10 empresas que operam com grãos diferenciados, identificaram os custos adicionais relacionados a armazenagem, segregação, gerenciamento de risco, transporte, análise e comercialização desse tipo de grão comparativamente ao grão commodity. Verificaram que $80 \%$ do produto diferenciado era entregue a granel, enquanto $20 \%$ era entregue ensacado.

\footnotetext{
${ }^{17}$ Intervalos de tempo na movimentação, para receber e expedir os produtos armazenáveis.

${ }^{18}$ Elevators são empresas que, nos EUA, atuam na área de armazenam e comercializam grãos no País.

Em 1997, havia cerca de 12.000 unidades, com uma capacidade estática de armazenamento superior a 230 milhões de toneladas (Sousa \& Marques, 1997).
} 
Os autores verificaram que esse custo médio representou um incremento de até US $\$ 0,21 /$ bushel no caso dos elevators e US $\$ 1,08 /$ bushel para as empresas que operam com grãos diferenciados. Considerando um preço médio da soja nos EUA em torno de US $\$ 5,50 /$ bushel, o aumento nos custos da negociação pode representar cerca de $4 \%$ no caso dos elevators e $20 \%$ para as empresas.

A tabela 1 apresenta esses resultados. Pode-se verificar que, no caso das empresas que operam com grãos diferenciados, o aumento do custo concentrase, principalmente, na segregação e no transporte do produto, representando $60 \%$ do custo.

Tabela 1. Custos adicionais incorridos por armazéns gerais de grãos e firmas que operam com soja diferenciada, para segregação do produto (em US $\$ /$ bushel $)^{19}$.

\begin{tabular}{lcc}
\hline Tipo de custo (adicional) & $\begin{array}{l}\text { Armazéns } \\
(\mathrm{N}=24)\end{array}$ & $\begin{array}{c}\text { Gerais } \\
\text { Firmas que operam com } \\
\text { soja diferenciada }\end{array}$ \\
\hline Armazenagem (por mês) & 0,02 & 0,10 \\
Acondicionamento/segregação & 0,06 & 0,27 \\
Gerenciamento de risco & 0,08 & 0,01 \\
Transporte & 0,02 & 0,39 \\
Análises/testes & 0,01 & 0,02 \\
Comercialização & 0,02 & 0,09 \\
Outros & 0,00 & 0,21 \\
Total & $\mathbf{0 , 2 1}$ & $\mathbf{1 , 0 8}$ \\
\hline
\end{tabular}

Fonte: Bender et al. (1999)

${ }^{19} 1$ bushel equivale a aproximadamente $27,2 \mathrm{~kg}$ de soja. 
No caso brasileiro, para este tipo de armazenagem a granel, ainda predominam os chamados armazéns verticais, sem divisões internas, o que, portanto, impossibilita a segregação e diferenciação do produto por qualidade e tipo. Nesse sentido, o governo teve um papel preponderante no desestímulo à busca da preservação da qualidade na medida em que, ao longo de várias décadas no passado, foi o maior detentor de estoques agrícolas do País, e não teve preocupação com a remuneração por qualidade ${ }^{20}$. Essa situação gerou uma seleção adversa ao tipo de instalação preferido pelos investidores no setor. De fato, considerando que o custo de construção de silos horizontais é mais elevado e não havendo incentivo para a segregação do produto (via premiação por qualidade), os investimentos em construção de silos foram direcionados para aqueles que não permitem a diferenciação do produto. Como conseqüência, muitas das instalações atuais no Brasil necessitariam de investimentos para permitir a preservação da identidade dos grãos.

Em situações mais específicas, há necessidade de se acondicionar o produto em sacas, associando determinado lote a um produtor específico - ou grupo de produtores -, permitindo a rastreabilidade do produto, como no caso do café ou de produtos orgânicos. Neste caso, os custos são muito mais elevados, implicando aumento do monitoramento no acondicionamento, necessidade de aquisição da sacaria, maior manuseio (encarecendo a mão-de-obra) e aumento dos custos de transporte.

Um outro aspecto particular ao ambiente institucional brasileiro, no que tange ao sistema de armazenagem, refere-se ao atual período de transformações estruturais deste setor. O sistema armazenador, vigente até o início do ano

\footnotetext{
20 Uma medida de grande efeito negativo para a manutenção da diferenciação do produto pelo seu tipo e qualidade refere-se a uma medida governamental que, em junho de 1989 , deixou de adotar o padrão 1/2/3 (sendo o padrão 1, o de melhor qualidade e o três, o de pior), como referência para suas aquisições. Já que o produto era misturado nos seus estoques de forma indiscriminada, optou por balizar todo os tipos para o $\mathrm{n}^{\circ} 3$ e peneira $1 \mathrm{~mm}$, adotando nos leilões oficiais ofertas de milho simplesmente "abaixo" e "acima" do padrão. Dado que o governo era o principal comprador e formador de estoques de milho na época, essa medida acabou por disseminar a prática de se nivelar o produto por baixo.
} 
2000, reporta-se a uma legislação que remonta ao início do século $X X$, promulgada em 1903. Em março de 2000, no entanto, foi aprovada uma nova legislação, que dispõe sobre novas diretrizes para o sistema. De maneira geral, são propostas alterações importantes, que terão impacto direto para a maior eficiência dos processos de PI. Entre elas, podem-se citar duas:

- geração de maior confiabilidade ao sistema, pela redefinição de responsabilidades do armazenador e do sistema de garantias e seguro. Além disso, criação de um sistema de certificação de qualidade técnica e operacional às unidades.

- autorização para a atividade comercial dos armazéns (proibida, até então, para o mesmo tipo de produto objeto de armazenamento ${ }^{21}$ ), incorporando cerca de 6.000 novos agentes ao sistema, os quais poderão exercer um papel fundamental na seleção, monitoramento e relação comercial com os produtores no sistema de PI. A exemplo dos elevators americanos e acopiadores argentinos ${ }^{22}$, as empresas armazenadoras no Brasil poderiam adquirir grãos diferenciados a custos de transação bem inferiores aos das grandes companhias, que são obrigadas a montar onerosas estruturas para gerenciar e monitorar o sistema. Esses novos comerciantes poderiam reunir maiores volumes de grãos e revendê-los (ou repassá-los, a partir de contratos de parcerias) às grandes indústrias ou tradings, com custos de transação inferiores, visto que as unidades armazenadoras constituem-se em estruturas menores ${ }^{23}$ e mais "enxutas", com forte inserção no microambiente do produtor rural. $A$ indústria também seria beneficiada, na

\footnotetext{
${ }^{21}$ O decreto n. 1.102, de 21 de novembro de 1903, que instituiu regras para o estabelecimento de armazéns gerais, era taxativo em seu artigo $8^{\circ}$, parágrafo $4^{\circ}$, quando afirmava que "não podem os armazéns gerais exercer o comércio de mercadorias idênticas às que se propõem receber em depósito, e adquirir para si ou para outrem, mercadorias expostas à venda em seus estabelecimentos, ainda que seja a pretexto de consumo particular".

${ }^{22}$ Para maiores informações sobre o papel dessas empresas, respectivamente, nos EUA e na Argentina, sugere-se Sousa \& Marques (1997) e Sousa \& Marques (1998)

${ }^{23}$ Segundo levantamento da Companhia Nacional de Abastecimento (CONAB), realizado em agosto de 1997, a média da capacidade estática dos armazéns gerais graneleiros no País era de 9,4 mil t/unidade.
} 
medida em que poderia reunir grandes lotes, com custos de transação menores.

iii) custos adicionais no transporte:

Segundo Graça (2000), a fase de transporte de grãos com necessidade de PI representa importante fonte de contaminação por outros produtos, principalmente em função da não exclusividade de frotas de caminhões e terminais ferroviários e portuários durante o período de safra. A segregação de grãos apresenta custos adicionais relativos aos seguintes aspectos:

- custo de carregamento e transporte do produto ensacado, mais oneroso do que a granel;

- necessidade de limpeza de carretas, vagões e compartimentos de navios antes do carregamento do produto, assim como moegas, armazéns e esteiras de transporte nos pontos de embarque do produto, e

- lacre dos compartimentos de carga (containers), para evitar sua violação.

iv) custos adicionais no processamento industrial:

Bucckwell et al. (1988) sugerem que a adição de custos nesta fase está diretamente relacionada: i) ao número de produtos secundários produzidos em uma determinada planta industrial e ii) se há volume suficiente de oferta de produto com PI que justifique uma planta dedicada ao processamento dessa matéria-prima.

No primeiro caso, quando há variedade de produtos secundários, serão gerados custos adicionais relacionados à limpeza periódica, o que implica um 
maior periodo de paralisação da fábrica. Assim, se apenas um dos produtos finais tiver que ter PI, por exemplo, farelo de soja não transgênica, esse produto suportará todo esse custo adicional. Se houver um mercado para vários produtos com $\mathrm{PI}$, esses custos serão diluídos por todos os produtos finais. No segundo caso, quando compensar financeiramente a existência de uma planta dedicada, não haverá custos adicionais de segregação de processamento e armazenagem.

Além desses, verificam-se custos adicionais relativos à obtenção de amostras e realização de testes para garantir especificação de qualidade e/ou para conferir os niveis de tolerância de contaminação requeridos. Há, também, incidência de custos e tempo adicionais, no caso de se precisar a rotulagem do produto, para se desenhar, revisar e atualizar a impressão de rótulos.

Assim, podem-se sumarizar os principais fatores que determinam os custos de reconversão e de operacionalização produtiva do sistema de $\mathrm{PI}$ - conforme Figura 6 -, quais sejam:

- tolerância à contaminação: quanto maior a exigência de pureza, maior o custo do sistema de PI;

- aspectos agronômicos: a disposição genética para polinização cruzada terá significativo impacto na formação de custos na fase de produção agrícola, incluindo a produção de sementes; necessidade de capacitação humana, adequação de máquinas e eventuais perdas de produtividade da terra também terão importância na adição de custos;

- especificidade temporal: uma sazonalidade muito significativa da oferta poderá elevar os custos de armazenagem em um sistema $\mathrm{PI}$, particularmente se houver uma especificidade locacional associada; 
- quantidade de produtos derivados: os custos unitários de PI no processamento industrial dependerão da possibilidade de se diluir por um número maior de subprodutos que dependam de PI.

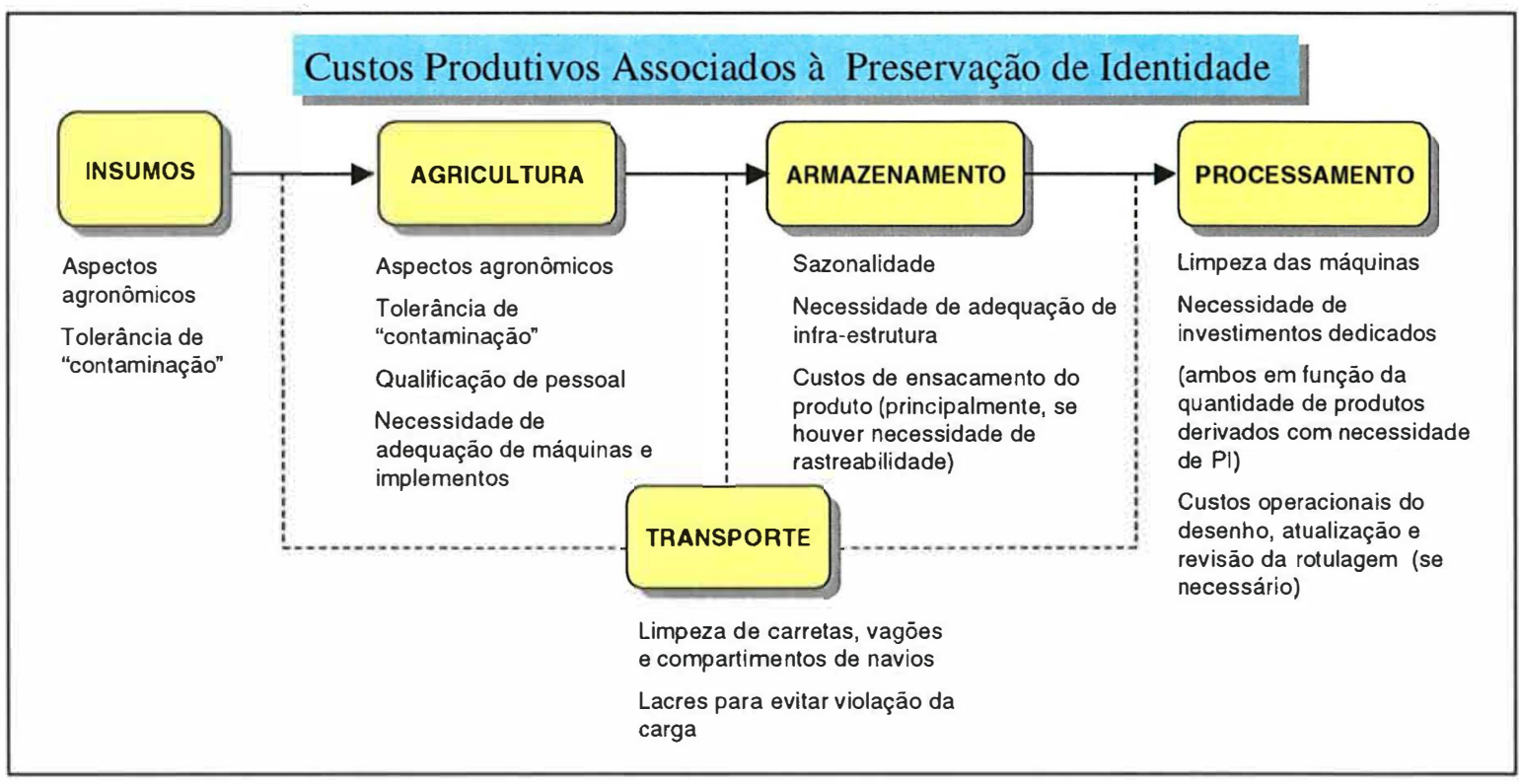

Fonte: elaborado pelo autor, a partir da revisão bibliográfica

Figura 6. Custos de conversão e operacionalização produtiva do sistema de PI relacionados às características do produto e do processo, nas diversas fases do SAG.

Dessa forma, espera-se que os incentivos sejam proporcionais aos custos de reconversão e operacionalização necessários. Quanto mais difícil a recuperação do investimento, maior será a necessidade de estímulo. 


\subsubsection{Custos do desenho do contrato}

Este custo está relacionado a dois aspectos: à complexidade dos termos contratuais e à necessidade da renegociação do contratos ou a sua freqüência. Assim, quanto mais complexos forem os termos e menor a freqüência de renegociação, maiores serão os custos envolvidos. Em situações de alta especificidade de ativos, baixa freqüência de transação implica custos fixos elevados associados à coleta de informações e à elaboração de um contrato complexo que imponha restrições ao comportamento oportunista. Como exemplo, pode-se citar o custo de oportunidade do gerente da empresa para renegociar os termos dos contratos, ao discutir situações não previstas; na ausência de regularidade do contrato, essas controvérsias tendem a ser mais freqüentes.

A necessidade de renegociação está, também, associada à racionalidade limitada dos agentes. Assim, variáveis como a transparência na formação do preço e padrões de classificação bem definidos são importantes fatores de redução deste custo de transação.

\subsection{Custos de monitoramento}

Segundo Hobbs (1996), os custos de monitoramento surgem após a transação e referem-se à necessidade de controlar a qualidade do produto e/ou do processo ou monitorar o comportamento dos vendedores e/ou compradores para garantir que todos os termos do contrato serão cumpridos. Para efeito da presente análise, os custos de monitoramento estarão fortemente vinculados à assimetria informacional.

O aparato institucional (como sistemas de padronização e de classificação, assim como selos de qualidade) e os processos de coordenação que permitam 
a identificação da origem são instrumentos importantes para a manutenção de atributos diferenciados e da qualidade do produto. Serão apresentados alguns desses conceitos que permitirão uma melhor compreensão das formas de coordenação dos SAGs em que há a necessidade da PI. Serão discutidos aspectos de padronização e certificação e, posteriormente, o conceito de rastreabilidade.

\subsubsection{Padronização e Certificação}

\section{a) Padronização}

Farina (1999:6), citando David \& Greenstein (1990), apresenta o conceito de padrão como "um conjunto de especificações técnicas, às quais adere um produtor voluntária ou compulsoriamente, tácita ou formalmente". A autora sugere que as especificações teriam como função principal a redução de custos de transação, pela determinação de referências e compatibilidades. Assim, um sistema de padronizaçao eficiente permite a redução de custos como aqueles associados à "identificação de fornecedores e/ou distribuidores, a negociação dos termos de troca, o monitoramento e controle do efetivo cumprimento dos mesmos, seja no que se refere às características físicas do bens transacionados, seja em relação a prazos e serviços associados".

A padronização pode ser desenvolvida pelo governo (bem público), associações profissionais (bem coletivo) ou por firmas dominantes (bem privado).

O Estado exerce um importante papel provendo a adoção de padrões que permite ganhos relacionados à comparabilidade $e$ intercambialidade (Kindleberger, 1983:377). O sistema de classificação oficial das commodities agrícolas, por exemplo - que estabelece padrões relacionados a impureza, 
umidade e número de defeitos, entre outros - representa um importante redutor de custos de transação. Se os atributos designados atenderem aos padrões desejados pelos agentes, as negociações podem ser feitas diretamente em bolsas de mercadorias e de futuros, envolvendo, inclusive, compradores e vendedores de diferentes países. Essa operação reduz sensivelmente os custos da busca do produto no mercado.

Neste sentido, Sousa et al. (1998) alertam para a ocorrência de custos incorridos pelas empresas quando há falhas nesta classificação oficial. Os autores citam o caso da classificação oficial do milho no Brasil que, defasada, não mais atende a critérios de padrão mínimos exigidos, tanto para a agroindústria alimentícia como a de formulação de rações. Nesse caso, grande parte das indústrias é obrigada a aumentar seus custos, desenvolvendo contratos particulares com produtores, em que são fixados ágios e deságios segundo uma tabela de classificação própria.

Em uma situação mais específica, as associações podem desenvolver padrões de qualidade diferenciados, cujo produto final seja identificado por selos que sinalizem ao produto uma qualidade superior. Nesse caso, criam-se subsistemas estritamente coordenados, como no caso do CACCER (Conselho das Associações do Café do Cerrado), descrito por Saes \& Jayo (1998), que busca a apropriação de quase renda gerada pela diferenciação do produto. A padronização do "Café do Cerrado", sem ignorar a classificação por número de defeitos, estabelece uma escala que também leva em conta atributos como a fava, coloração do grão e altitude da área de produção.

Finalmente, há ainda padrões estabelecidos por empresas dominantes de um determinado setor como redes internacionais de fast food ou grandes redes de supermercado que adotam padrões compativeis com a estratégia de concorrência adotadas, que balizam o processo produtivo dos fornecedores. 


\section{b) Certificação}

Segundo Nassar (1999), em seu conceito amplo, a certificação é a definição de atributos de um produto, processo ou serviço e a garantia de que eles se enquadram nestas normas pré-definidas. Coklin \& Thompson (1995), citados por Souza (1998), afirmam que a certificação de produtos oferece aos consumidores informações objetivas sobre a qualidade de um determinado produto. Em última análise, constituem instrumentos de redução do custo da informação ao consumidor e, consequentemente, dos custos de transação em mercados com produtos heterogêneos.

Assim, a certificação envolve normas, seja na esfera privada, pública ou internacional (ambiente institucional), seja por meio de um órgão certificador com poder de monitoramento e exclusão (ambiente organizacional). A certificação pode envolver aspectos relacionados aos atributos do produto, ao processo produtivo e às relações deste último com o meio-ambiente. Nunes (1999) afirma que "quem determina quais os atributos passíveis de certificação é, em última instância, o consumidor, que paga para ter certeza de que está adquirindo produtos em conformidade com suas preferências".

Peri \& Gaeta (1999) destacam que os selos de qualidade são baseados em padrões, cujas especificações devem ser mensuráveis, verificáveis e controláveis. É, em última análise, um sinal de rápida identificação e de diferenciação para o consumidor.

Nassar (1999) sugere dois principais objetivos para a certificação: do lado da oferta, pretende garantir um conjunto de atributos do produto por meio de um instrumento de certificação, freqüentemente na forma de um selo ou certificado. Nesse caso, a certificação cria um instrumento de exclusão e seleção de firmas e produtos. 
Do lado da demanda, a certificação espera convencer o consumidor que determinado produto tem certos atributos por ele procurados (produtos orgânicos, produtos com origem conhecida, produtos diretos da fazenda etc).

Assim, o autor sugere que a certificação estaria baseada em dois objetivos:

(i) criar incentivos à cooperação horizontal e vertical entre firmas, e

(ii) gerar benefícios aos consumidores, reduzindo a assimetria informacional sobre o produto consumido.

\section{b.1 A certificação no agribusiness}

A certificação é um sistema de coordenação vertical das cadeias produtivas, que procura garantir a qualidade dos seus produtos segundo determinadas necessidades e desejos específicos dos consumidores. Qualidade é, aqui, entendida em seu conceito amplo, e pode dizer respeito a todos os produtos do agribusiness, sejam eles alimentos ou matérias primas para a indústria.

Espera-se que, a crescente preocupação do consumidor final com a segurança do alimento, leve ao aumento da utilização de mecanismos de certificação nos sistemas agroindustriais. E, ainda, que a necessidade desse processo esteja diretamente relacionada ao nível de assimetria informacional entre o consumidor e o produtor rural.

No mercado de commodities, os atributos relevantes das mercadorias são razoavelmente conhecidos por compradores e vendedores. Por outro lado, em mercados de produtos diferenciados, muitas vezes, vendedores e compradores têm acesso diferenciado a informações sobre o processo produtivo e sobre a manipulação do produto, como no caso da soja orgânica. Nesse caso, a certificação exerce o papel de restaurar a transparência de mercados em que a 
informação não é compartilhada igualmente por vendedores e compradores e a verificação dos atributos relevantes é custosa. Facilita o acesso ao mercado externo pois há uma rede internacional de entidades certificadoras, comprometidas com as mesmas normas.

Farina (1999) associa a forma mais eficiente de monitoramento/controle entre os agentes à visibilidade dos atributos desejados - relacionada ao grau de assimetria informacional. Assim, quando os atributos do produto são mais facilmente visiveis ao consumidor, espera-se que o monitoramento feito pelos próprios agentes do mercado envolvidos seja a forma mais eficiente. Por outro lado, em situações em que estão envolvidos processos de difícil visibilidade e identificação, a certificação ou arbitragem de um terceiro (como empresa certificadora ou associação) deve ser a forma redutora de custos para diminuição da assimetria informacional. Além disso, deve-se destacar que o processo de certificação envolve custos, os quais devem ser ponderados com os prêmios correspondentes, para avaliar a sua viabilidade econômica.

\section{b.2 Formas de certificação}

Como já mencionado, freqüentemente, os agentes recorrem ao serviço de terceiros, que são as empresas certificadoras, e que assumem a responsabilidade de transmitir ao consumidor uma determinada informação que se perderia na cadeia produtiva. Hauselmann (1996) define o papel da certificadora como o procedimento pelo qual uma terceira parte assegura, por escrito, que um produto, processo ou serviço está de acordo com requisitos específicos.

Um exemplo representativo de empresa certificadora, para produtos orgânicos é a IFOAM (International Federation of Organic Agriculture Movement). Souza (1998:25) descreve o papel desse instituto como o de exercer a coordenação 
do processo, reduzindo "drasticamente" a assimetria de informações entre as partes envolvidas. Essa federação atua na harmonização de normas e credenciamento de agências certificadoras ${ }^{24}$, que por sua vez, monitoram a aplicação das regras de produção e de processamento da matéria-prima, antes de emitir o certificado ${ }^{25}$.

Outros exemplos de certificação são o "Selo de Pureza", emitido pela Associação Brasileira da Indústria do Café - ABIC (descrito por Saes \& Farina, 1998) e aquelas associadas a denominações de origem, como a marca "Café do Cerrado", cuja estratégia de diferenciação baseia-se na qualidade do produto daquela região. Além dessas, pode-se citar a empresa Genetic ID, pioneira na certificação de organismos não geneticamente modificados (nãoOGM's), que será objeto de análise no capítulo 5 e que, por meio de testes, exames de documentação e auditorias, atesta se um determinado lote de produto é livre de OGM's. Nesse caso, o que tem valor é o nome e reputação do certificado emitido. O rigor da análise, por sua vez, é o que permite a consolidação do valor dessa reputação.

Nos exemplos apresentados, a certificação é realizada por uma terceira parte, seja uma associação de classe, seja uma certificadora. Em situações de grande reputação da empresa envolvida, ela mesma pode desenvolver uma relação de confiança com o seu consumidor. Produtos de marca própria dos supermercados são um exemplo: o selo da rede para vender produtos agrícolas é uma forma de agregar reputação da marca do supermercado ao produto. Neste caso, há um trabalho rígido de contratação junto a produtores e distribuidores desses produtos, já que a reputação da empresa é que fica

\footnotetext{
${ }^{24} \mathrm{O}$ credenciamento é o procedimento pelo qual um órgão autorizado reconhece formalmente que uma pessoa ou organização tem competência para desenvolver determinadas tarefas.

${ }^{25} \mathrm{O}$ Instituto Biodinâmico de Desenvolvimento Rural (IBD), com sede em Botucatu-SP é um exemplo de empresa certificada pelo IFOAM. O IBD inspeciona o processo, realiza a certificação e concede o uso do Selo de Qualidade, que mostra a procedência dos produtos orgânicos ou biodinâmicos. Este selo indica que o estabelecimento rural ou indústria processadora satisfaz as diretrizes de produção e processamento definidos nas normas.
} 
exposta. Isso gera uma relação de fidelidade entre consumidor e supermercado, dando credibilidade ao produto in natura, via reputação do supermercado. Grandes empresas alimentícias, como Nestlé ou Sadia, também desenvolvem esta credibilidade e, em muitas situações, podem dispensar a contratação de uma empresa independente. A sua marca já é para muitos consumidores uma garantia de que aquele é um produto confiável, com procedência. Nesse caso, a reputação é o valor intrínseco da empresa, construída a partir da repetição de compras e associação daquela empresa a qualidade.

Deve-se destacar, ainda, a importância do desenvolvimento de processos tecnológicos de medição que ajudam a identificar e quantificar alterações nos atributos dos produtos. Testes de análise laboratoriais podem diminuir, de forma significativa, os custos de monitoramento e rastreabilidade ou, até mesmo, substitui-los em algumas situações.

Como exemplo, tem-se os testes para identificação de produtos transgênicos. De fato, segundo Cesare \& Cordeiro (1999), várias empresas vêm investindo no desenvolvimento de kits que permitem a rápida detecção de grãos transgênicos a um baixo custo, prática que diminui sensivelmente os custos envolvidos na segregação do produto $\mathrm{GM}$, rejeitado por grande parte de consumidores em diversos países.

Segundo Azevedo et al. (2000), os testes atualmente disponíveis para diagnosticar a presença de soja GM são feitos através dos métodos de Imunoanálise (ELISA) ou PCR (Polymerase Chain Reaction). O primeiro teste, apesar do fornecimento do resultado em período mais curto, é considerado menos eficiente para diagnosticar e identificar a presença de OGMs do que o segundo ${ }^{26}$. No que diz respeito aos custos, Graça (2000) constatou que o custo

\footnotetext{
${ }^{26} \mathrm{O}$ tempo médio para obtenção do resultado do teste Elisa é de aproximadamente 10 minutos e apresenta um nivel de precisão de $0,1 \%$. O método PCR leva 24 para obtenção do resultado (mais cerca de 5 dias no caso de envio ao exterior), e apresenta nível de precisão de $0,01 \%$
} 
médio do teste PCR é de US $\$ 350,00$, sendo que cada amostra pode representar o volume de 5.000 a $6.000 \mathrm{t}$, o que representa um sobre-custo de US\$ 0,07/t. Já o custo do teste ELISA é de US $\$ 10,00$, para uma amostra representativa de uma carreta (25 t); ou seja, cerca de US\$ $\underline{0,40 / t}$. Assim, embora o custo unitário da análise PCR seja mais elevado, seu custo por tonelada é bem inferior, além do que esta é a única análise levada em consideração para fins de certificação de produtos não-GM.

Outro exemplo de processos tecnológicos de medição que ajudam a identificar e quantificar alterações nos atributos dos produtos é citado por Schroeder (1999), que menciona o espectômetro quase infravermelho e que permite a medição acurada e eficiente do conteúdo protéico e oleaginoso dos grãos de soja no momento em que são entregues ao comprador. Essas tecnologias viabilizam a medição de atributos que atendam aos interesses dos consumidores e funcionam como um importante redutor de custos de transação no que se refere ao monitoramento e controle da produção.

A possibilidade de o teste ser realizado em todas as fases da cadeia produtiva inclusive na propriedade rural -, permite a diminuição de ações oportunísticas e, consequentemente, da necessidade de um sistema complexo de rastreabilidade de grãos. A sua maior difusão estará diretamente relacionada ao aumento da praticidade na realização do teste e à diminuição do seu custo e tempo para obtenção dos resultados. No entanto, deve-se destacar que a análise do produto isoladamente, com o objetivo de garantir a $\mathrm{PI}$, tende a apresentar vantagens em relação ao monitoramento do processo - como a certificação ou rastreabilidade - , somente em situações específicas. Podem-se citar duas situações em que os testes laboratoriais trariam vantagens - principalmente econômicas, em relação à certificação:

- quando a probabilidade de "contaminação" for muito remota (incerteza): atualmente, dada a proibição do plantio de transgênico no Brasil, muitas 
tradings têm vendido soja não transgênica ao mercado europeu, mediante o pagamento de algum prêmio, utilizando somente testes PCR. Isso é possível em função da pequena probabilidade de que lotes, originados principalmente na região Centro-Oeste, tenham porcentagem de OGMs superior a $1 \%$, padrão exigido pela maior parte dos países europeus ${ }^{27}$. Esta prática não seria viável para o produto comprado nos Estados Unidos ou na Argentina. Nesses países, cerca de $50 \%$ e $75 \%$, respectivamente, da área plantada em 1999 era de soja transgênica e, portanto, a probabilidade de se receber lotes transgênicos nos locais de entrega, de forma aleatória, seria muito elevada. Nesses casos, há necessidade de um processo de monitoramento e certificação.

- em situações em que a freqüência das transações é muito reduzida: pois, em uma situação oposta, em que haja a necessidade da realização de muitos testes, devido a um número grande de entregas de lotes, pode ser preferível a obtenção da certificação do processo, evitando custos dos exames laboratoriais a cada entrega de produto.

Finalmente, cabe destacar que o processo de certificação pode ocorrer nas diversas fases que se sucedem ao longo do fluxo do Sistema Agroindustrial, implicando custos e benefícios diferenciados. Assim, pode-se certificar: i) na originação, controlando-se a etapa produtiva agrícola até a unidade processadora; ii) na transformação do grão, monitorando a matéria-prima na etapa industrial, iii) os lotes de produto, operação que pode ser feita, por exemplo, na recepção do produto no porto importador. Azevedo et al. (2000) sugerem as principais vantagens e desvantagens, segundo o tipo de certificação, avaliando as três situações, para a certificação de produtos nãoGM's, conforme o Quadro 7.

\footnotetext{
${ }^{27}$ Sabe-se que, apesar dessa proibição, há indícios de significativa entrada de soja clandestina, principalmente da Argentina. No entanto, dadas as características agronômicas das variedades da soja oriundas daquele país, elas se adaptam melhor na região sul do Brasil, razão pela qual é lá que, se estima, esteja concentrada a maior parte do plantio de soja transgênica ilegal no País.
} 


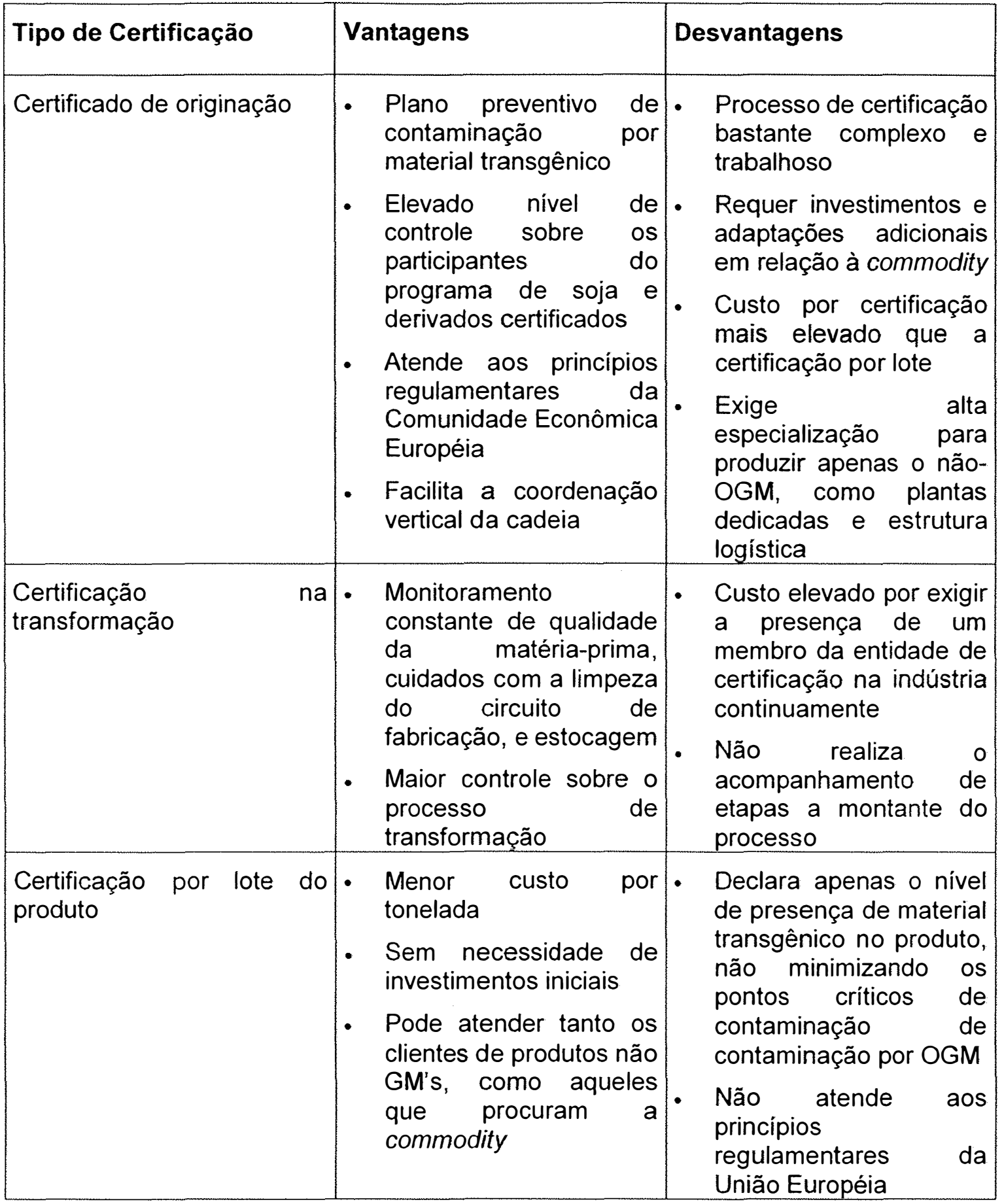

Fonte: Azevedo et al. (2000)

Quadro 7. Tipos de certificação para grãos livres não geneticamente modificados (não-OGM's): vantagens e desvantagens. 
A Figura 7 apresenta, esquematicamente, o processo de certificação e aspectos relacionados a este processo.

\section{CERTIFICAÇÃO}

Agentes:empresas certificadoras, associaçōes de classes, empresas com reputação Ações: monitoramento, preservação de identidade, realização de testes laboratoriais Condições: atributos difíceis de identificar e avaliar, assimetria informacional, interesse em diferenciação

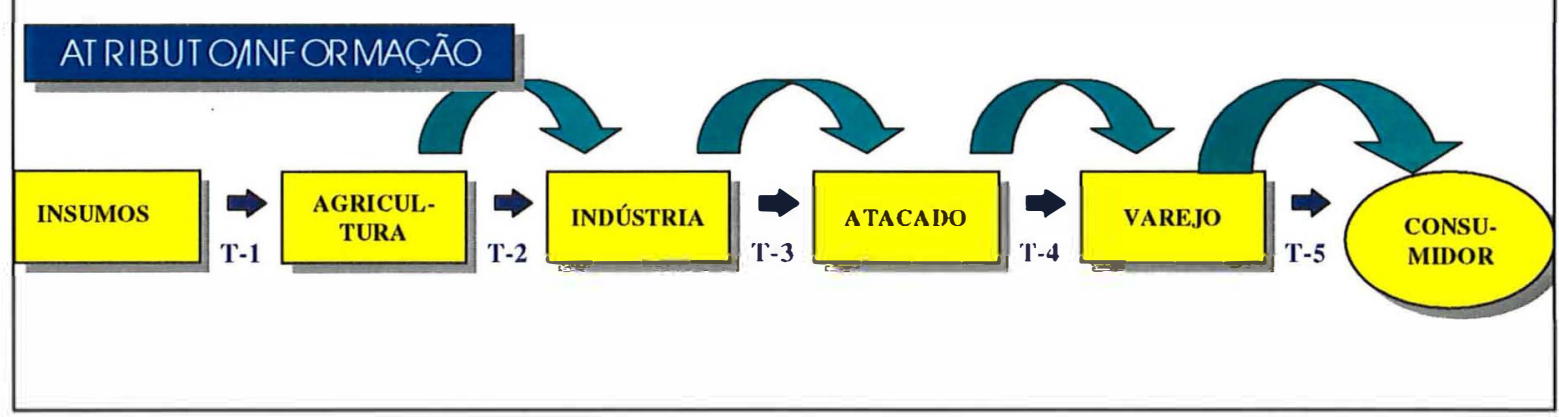

Fonte: elaborado pelo autor, adaptado de Nassar (1999)

Figura 7. Fluxograma esquemático do processo de certificação.

\subsubsection{Rastreabilidade}

O conceito de rastreabilidade para produtos agroindustriais começa a ganhar corpo com a ocorrência de problemas fitossanitários recentes, como no caso da crise da doença conhecida como "vaca louca", diagnosticada pela primeira vez na Inglaterra em 1986 e que afeta o sistema nervoso central dos bovinos ${ }^{28}$. Se, naquele momento, houvesse um sistema de rastreamento eficiente, o foco da doença poderia ser rapidamente identificado na sua origem e eliminado, além de responsabilizado o agente causador. Como não havia esse sistema, o governo se viu obrigado a tomar a decisão de dizimar praticamente todo o 
estoque de carne e o rebanho do país, gerando custos excessivos para toda a sociedade. A partir da reação dos consumidores a esses riscos, os agentes da cadeia produtiva passaram, então, a perceber a necessidade de identificar rapidamente a origem do problema, evitando maiores prejuízos.

Sans \& Fontguyon (1998), citados por Jank (1999:31), definem a rastreabilidade como "a capacidade de reencontrar o histórico, a utilização ou a localização de um produto qualquer através de meios de identificação e registrados". Ou ainda, rastreabilidade "é a capacidade de preservar a identidade do produto e suas origens" (Juran \& Gryna, 1992, v. 3, p. 301).

Segundo Lombardi (1998:90) o objetivo da rastreabilidade é "garantir ao consumidor um produto seguro e saudável, por meio do controle de todas as fases da produção, industrialização, transporte/distribuição e comercialização, possibilitando uma perfeita correlação entre o produto final e a matéria prima que the deu origem". Jank (1999, p. 33) afirma que "mais do que controlar os elos da cadeia de um produto, a rastreabilidade permite que se remonte as transações pelas quais passou um produto, dando nome e endereço aos seus agentes". Assim, o ponto básico em todo o programa de rastreabilidade é a possibilidade de identificar a origem, quando e se necessário.

Segundo Juran \& Gryna (1992), a rastreabilidade teria diversas finalidades, entre as quais: i) assegurar que apenas materiais e componentes de qualidade entrem em um produto final; ii) identificar clara e explicitamente produtos que são diferentes mas que se parecem a ponto de serem confundidos entre si; iii) permitir o retorno de produto suspeito numa base precisa; e iv) localizar causas de falhas e tomar medidas corretivas a custo mínimo.

\footnotetext{
${ }^{28}$ A Encefalopatia Espongiforme Bovina (EEB), conhecida como a "Síndrome da Vaca Louca" pode ser considerada um marco para o início da imposição da rastreabilidade de produtos agro-alimentares na Europa.
} 
Machado (1999 e 2000) complementa que a rastreabilidade traria beneficios distintos para os diferentes agentes da cadeia. Assim, para o consumidor mais exigente, traria salvaguardas à sua saúde, seria uma forma de diminuir incertezas e de satisfazer a necessidade de controle sobre a própria vida, além de ser vista como um fator de qualidade.

Do ponto de vista dos segmentos de distribuição, varejo e do segmento da indústria mais próxima ao consumidor supracitado, a rastreabilidade é importante, pois:

- é um fator diferencial de competitividade para o seu negócio junto ao público consumidor;

- fortalece a imagem institucional da empresa;

- ajuda a posicionar uma marca no mercado;

- estimula a concorrência através da estratégia da diferenciação pela qualidade;

- desenvolve relações entre fornecedores; e

- contribui para a construção de estratégias competitivas da empresa que, inclusive, passa a definir a estrutura de coordenação vertical da cadeia.

Finalmente, a autora aponta benefícios também para o Estado, na sua condição de provedor de serviços básicos de segurança alimentar, pois minimiza riscos de contaminação, além de ser um meio eficiente para localizar o foco de problemas do gênero; além disso, oferece maior tranqüilidade à população e maior credibilidade institucional. Assim, a rastreabilidade pode ser um processo voluntário, quando a empresa agrega um diferencial em competitividade que reverteria em beneficios ou um processo compulsório, quando o padrão é regulamentado pelas instituições públicas. 
Os benefícios apontados sugerem que haveria interesse dos vários agentes na implantação de um sistema de rastreabilidade. De fato, poderia ser implementado em qualquer tipo de alimento. Jank (1999) argumenta, porém, que o seu elevado custo induz a que o sistema se restrinja às situações em que ocorrem um ou mais dos seguintes fatores:

- elevada perecibilidade do produto e elevado risco de contaminação;

- necessidade de comprovação de inocuidade e sanidade em todos os elos da cadeia, já que permite a determinação de responsabilidades;

- existência de um mercado consumidor de produtos de alta qualidade, inclusive disposto a pagar mais por um produto rastreado; e

- casos especiais de controle sanitário estrito, por motivos religiosos ou de crença.

Poder-se-iam acrescentar, ainda, as preocupações relacionadas ao meioambiente e aspectos sociais. Assim, um determinado grupo de consumidores europeus poderá exigir que o café consumido não tenha envolvido mão-de-obra infantil na fase de produção agrícola nos países de origem. Ou ainda, que a madeira do móvel consumido não tenha sido explorada de forma predatória.

Um sistema eficiente de rastreabilidade poderá dar essa garantia adicional ao consumidor, no que se refere à possibilidade de se identificar a origem de um problema detectado na ponta do consumo; esse processo assume maior importância, quando houver o interesse, por exemplo, de se responsabilizar judicialmente o agente, em situações que envolvam a saúde e segurança alimentar. Em outras situações, sistemas de controle interno de empresas com alta reputação ou contratação de certificação por terceiros, poderiam ser suficientes para transmitir a credibilidade quanto à qualidade do produto ao consumidor, a um custo menor. Assim, a certificação não necessita, 
necessariamente, de rastreabilidade; a rastreabilidade, por sua vez, agrega informações à certificação.

Exemplo de um sistema de rastreabilidade já implantado é o da carne na Europa, cujo modelo permite a sua identificação desde o nascimento do animal até o produto ofertado no varejo, medida amplificada pelos temores gerados com a ocorrência da "doença da vaca louca". No Brasil, pode-se citar um sistema que permite a rastreabilidade: o SAG do leite tipo $A$, que é, obrigatoriamente, produzido, industrializado e embalado na propriedade rural.

Finalmente, a Figura 8 apresenta, esquematicamente, 0 processo de rastreabilidade e aspectos relacionados a este processo.

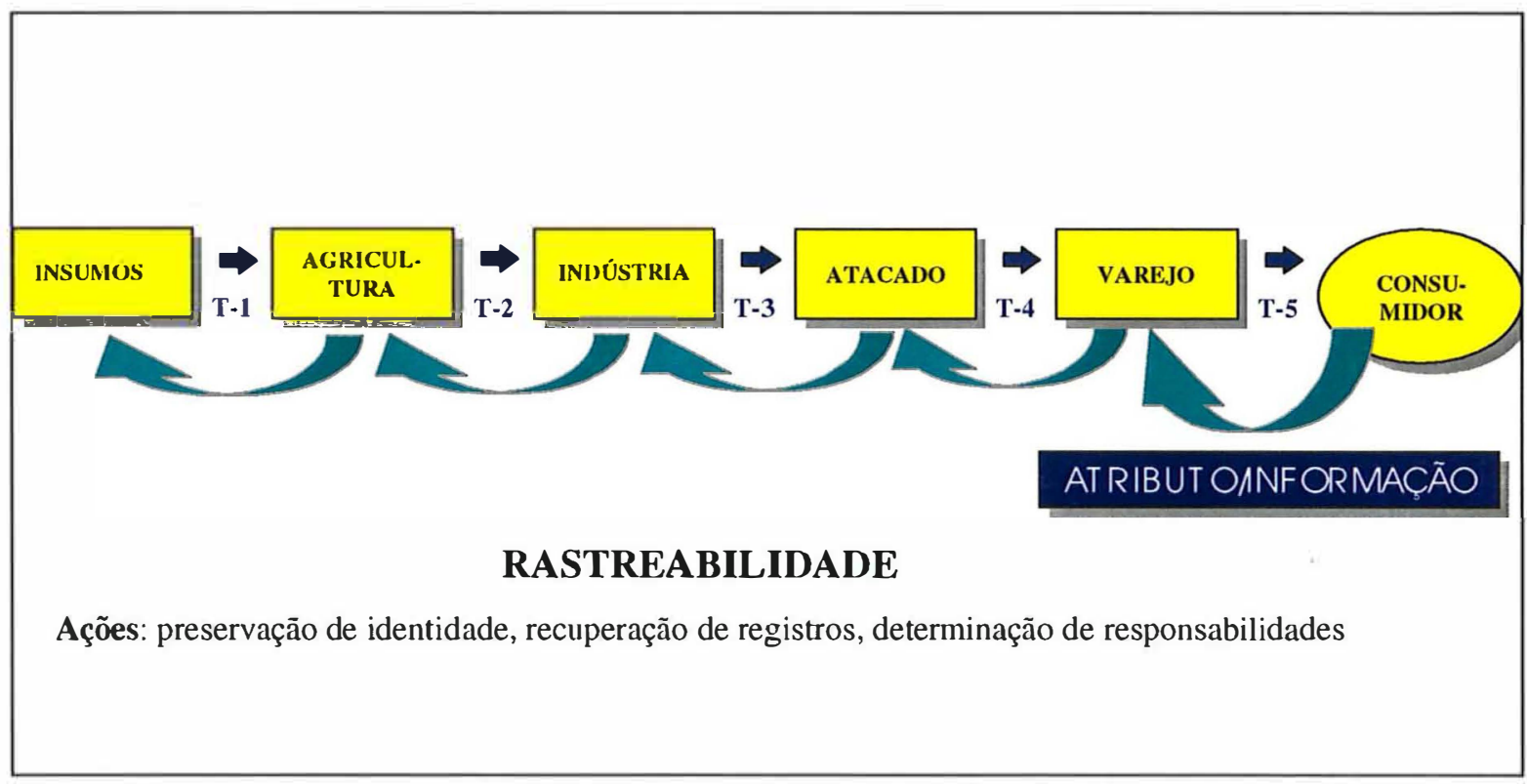

Fonte: elaborado pelo autor, adaptado de Jank (1999)

Figura 8. Fluxograma esquemático do processo de rastreabilidade. 


\subsection{Características das transações e arranjos contratuais}

Conforme descrito no capitulo 3 , os custos de transação associam-se aos atributos das transações - relacionados à freqüência, incerteza e especificidade dos ativos -, bem como aos pressupostos comportamentais. $A$ análise realizada neste capitulo identifica, além dos custos resultantes da necessidade de se preservar a identidade de grãos, os instrumentos redutores dos custos de transação. Pode-se observar, porém que, ao longo desta avaliação, a aplicabilidade desses mecanismos minimizadores de custos e falhas são, em algumas situações, fortemente condicionados a atributos especificos dos produtos.

Esta constatação é corroborada por Hobbs \& Young (2000) e pode ser observada na Figura 9. De fato, os autores reconhecem o papel das características das transações na determinação da estrutura de governança proposta por Williamson (1979), características essas que exercem influência decisiva sobre os custos de transação. Esta relação é demonstrada nos dois quadros da direita daquela figura. No entanto, os autores sugerem que as características das transações são, também, o resultado de certas características do produto que, por sua vez, serão condicionadas por condutores regulatórios (como imposição de rastreabilidade), tecnológicos (biotecnologia) e socio-econômicos (mudança nos padrões de consumo). Argumentam, ainda, que estes condutores exercerão, de forma análoga, impactos diretos sobre as características da transação, pela influência no ambiente em que estas transações estão ocorrendo. 


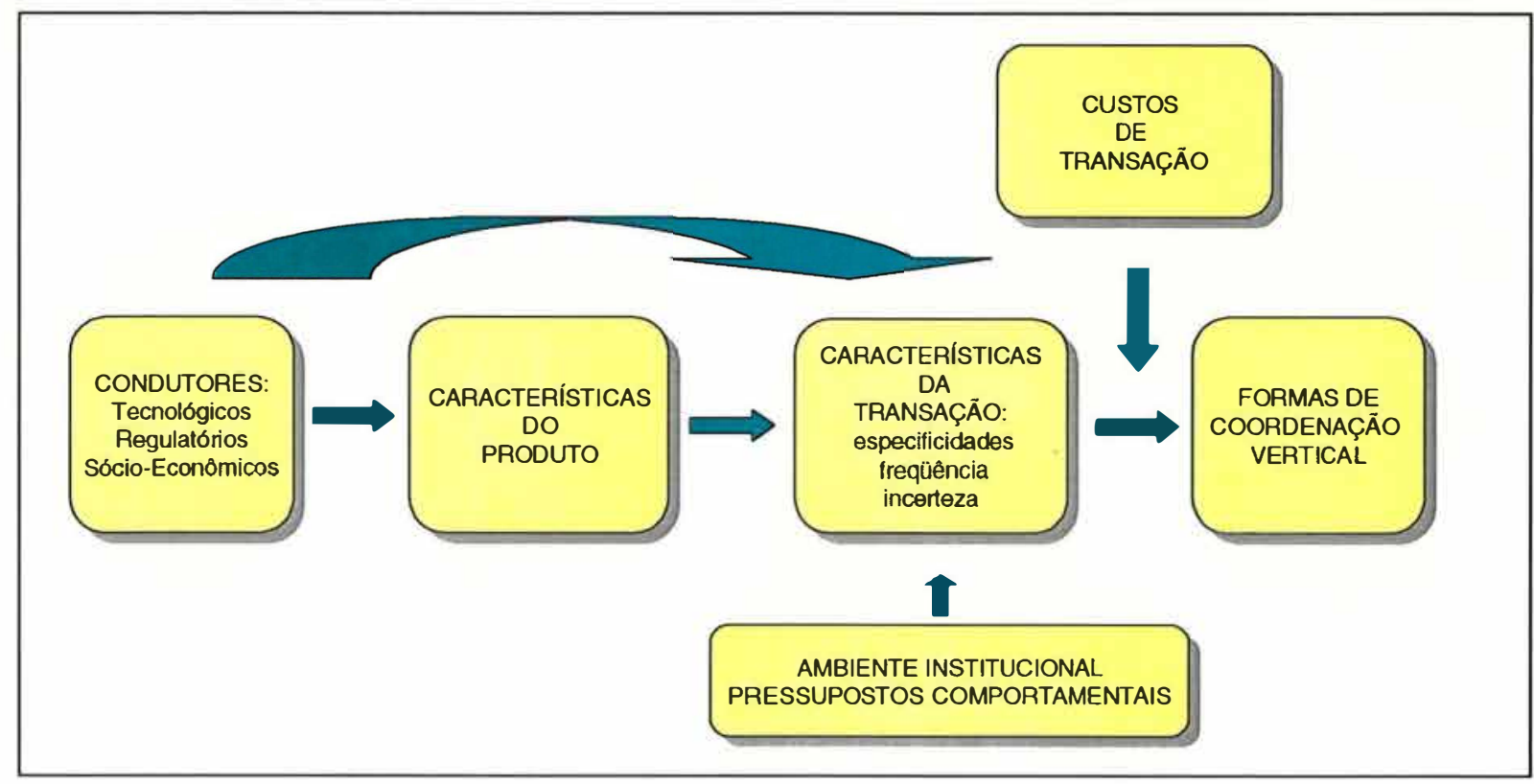

Fonte: Adaptado de Hobbs \& Young (2000)

Figura 9. Modelo conceitual de coordenação vertical, proposto por HOBBS \& Young (2000), a partir de Williamson (1985).

O Quadro 8, adaptado de Hobbs \& Young (2000), procura relacionar a forma pela qual as características do produto podem afetar as características da transação (incerteza, freqüência e especificidade do ativo) e, consequentemente, a estrutura de governança (ou forma de coordenação).

A primeira característica do produto apresentada diz respeito à sua perecibilidade. Essa condição gera incerteza quanto à qualidade e quantidade que o comprador irá receber. Da mesma forma, cria incerteza no vendedor quanto ao preço e localização de potenciais compradores, visto que produtos perecíveis devem ser removidos rapidamente para evitar deterioração, impedindo o seu armazenamento para aguardar condições mais favoráveis de mercado. Além disso, dada essa característica do produto, a transação deve ocorrer com maior freqüência. 


\begin{tabular}{|c|c|c|c|c|c|c|}
\hline \multirow{3}{*}{$\begin{array}{l}\text { Característica } \\
\text { do Produto }\end{array}$} & \multicolumn{3}{|c|}{ Característica } & \multicolumn{3}{|l|}{ Transação } \\
\hline & \multicolumn{3}{|c|}{ Incerteza } & & Freqüência & $\begin{array}{l}\text { Especificidade } \\
\text { do ativo }\end{array}$ \\
\hline & $\begin{array}{l}\text { Comprador } \\
\text { (qualidade) }\end{array}$ & $\begin{array}{l}\text { Comprador } \\
\text { (quantidade } \\
\text { pontualidade }\end{array}$ & $\begin{array}{c}\text { Comprador } \\
\mathrm{e} \\
\text { vendedor } \\
\text { (preço) }\end{array}$ & $\begin{array}{c}\text { Vendedor } \\
\text { (localizar } \\
\text { um } \\
\text { comprador) }\end{array}$ & $\begin{array}{l}\text { Freqüência } \\
\text { da transação }\end{array}$ & $\begin{array}{l}\text { Investimentos } \\
\text { dedicados }\end{array}$ \\
\hline Perecibilidade & $x$ & $x$ & & $\mathrm{X}$ & $x$ & \\
\hline $\begin{array}{l}\text { Diferenciação do } \\
\text { produto }\end{array}$ & $\mathrm{X}$ & $X$ & $\mathrm{X}$ & $\mathrm{X}$ & & $\mathrm{X}$ \\
\hline $\begin{array}{l}\text { Qualidade } \\
\text { variável/ visível }\end{array}$ & & $X$ & $\mathrm{X}$ & $X$ & & \\
\hline $\begin{array}{l}\text { Qualidade } \\
\text { variável/ invisível }\end{array}$ & $\mathrm{X}$ & $\mathrm{X}$ & $\mathrm{X}$ & & & \\
\hline
\end{tabular}

Fonte: Hobbs \& Young (2000)

Quadro 8. Modelo genérico das relações entre as características do produto e das transações.

No caso de produtos diferenciados, há, também, incerteza para compradores e vendedores. Do lado do comprador, ele terá menos opções de compra em relação aos produtos commodities, e o vendedor necessitará de mais garantias na venda. Além disso, ambos (compradores e vendedores) realizam investimentos especificos: o produtor, na diferenciação nas especificações requeridas; o comprador, na adequação de sua produção e distribuição dos produtos diferenciados. 
As duas outras características referem-se ao produto que apresenta determinados atributos de qualidade variáveis. No primeiro caso, quando o atributo é visivel, há incerteza do comprador, não em relação à sua qualidade, mas no que se refere à quantidade e pontualidade da entrega. Já, na segunda situação, quando não se percebe claramente a qualidade, há aumento da incerteza. No entanto, incerteza quanto ao preço surge sempre que o preço estiver relacionado com a qualidade. Tanto compradores quanto vendedores não podem ter certeza, com antecedência, sobre o valor que vão pagar ou receber antes da transação.

Azevedo (2000) oferece uma abordagem distinta no que se refere aos atributos dos produtos e sugere que as características intrínsecas a estes constituem-se em tipos de custos de transação. Não dependem de interação dos agentes ao longo do tempo. Por esse motivo, esses seriam custos chamados de estáticos, uma vez que independem do contexto temporal em que se desenvolvem. Barzel (1982) explora essa questão, relacionada às medidas dos produtos (measurement), analisando a sua caracterização segundo a capacidade de os agentes assimilarem as informações relevantes para o estabelecimento de uma relação de troca.

Para fins analíticos, podem-se apontar três tipos de grupos de produtos: o primeiro refere-se àquele, para cuja transação, todas as informações relevantes para são disponiveis; neste caso, as transações via mercado são as mais eficientes. No segundo grupo, algumas informações só podem ser obtidas após a transação, ou até mesmo após o consumo; contratos, regulamentação do Estado (com fixação de padrões rígidos e/ou punições) e o fortalecimento da reputação das empresas podem ser mecanismos para minimizar os custos envolvidos.

Finalmente, há os produtos para os quais não são obtidas algumas informações relevantes à transação nem após o consumo do produto. Essa característica, 
segundo Azevedo (2000:38), "torna o problema derivado da assimetria de informação não apenas custoso, mas insolúvel por inspeção direta nos produtos". Por esses motivos, tais produtos são denominados 'bens de crença'. Exemplo ilustrativo deste grupo é o frango destinado ao mercado muçulmano. O mercado de consumo exige que as aves sejam abatidas segundo os preceitos do Alcorão, o que implica uma mudança da linha de abate segundo sua posição em relação à Meca. Neste caso, o produto não contém as informações, sendo necessária a observação do processo de produção.

De qualquer forma, pode-se verificar que, independentemente da abordagem considerada (seja aquela trazida por Hobbs \& Young, 2000, seja a mais clássica, desenvolvida por Barzel, 1982), as características dos atributos dos produtos exercem significativo papel no processo de coordenação do vertical do sistema. Assim, o que se pretende nos próximos capítulos é identificar quais seriam as formas de minimizar os custos associados à informação, negociação e monitoramento, dadas as características das transações e dos produtos de cada caso analisado, bem como o ambiente institucional em que essas transações se inserem. Serão também analisados mecanismos relacionados a incentivo, controle, tecnologia de informação e o desenvolvimento de bens públicos e coletivos, conforme a metodologia do trabalho descrita no próximo capítulo. 
4 MATERIAL E MÉTODOS 


\section{MATERIAL E MÉTODOS}

Como metodologia deste trabalho serão apresentados estudos empíricos de empresas que desenvolveram estratégias visando à preservação de identidades de grãos, enfocando, prioritariamente, a relação produtoragroindústria. A princípio, este é um trabalho de natureza teórica, conjugado com análise descritiva de experiências emergentes. O estudo de caso como método científico propicia uma visão microanalítica da realidade de negócios e, apesar de não permitir generalizações, possibilita uma avaliação da realidade organizacional e de negócios das empresas, além da verificação de evidências quanto às organizações teóricas. Permite, ainda, observar novos elementos a serem considerados.

Bialoskorski Neto (1998:158) afirma, também, que "o estudo de caso permite olhar detidamente os problemas, privilegiando sua compreensão no próprio ambiente de negócios em que acontecem. Não há o isolamento da variável nem, tampouco, os limites ditados pelos pressupostos colocados. Deste modo, podem-se entender as relações entre os parâmetros estudados e o ambiente em que correm sistematicamente." Mattar (1993:82), destaca que as pesquisas apoiadas em estudos de casos podem ser consideradas "estudos profundos, mas não amplos, através dos quais se procura conhecer profundamente apenas um ou poucos elementos da população sobre um grande número de aspectos e suas inter-relações".

No caso da presente pesquisa, optou-se por estudo de casos múltiplos, cuja 
vantagem reside no fato de que estes proporcionam evidências inseridas em diferentes contextos, o que acaba tornando a pesquisa mais robusta (Lazzarini, 1997). O método será então utilizado como um instrumento de investigação e estudo complementar das discussões teóricas apresentadas nos capítulos anteriores. De fato, segundo Lazzarini (1997:p. 19), "a existência de um referencial teórico prévio torna-se particularmente importante para a pesquisa baseada em estudo de caso: este referencial irá servir como uma espécie de "matéria-prima" que será moldada a partir das evidências obtidas com o estudo".

Essa vantagem torna-se particularmente importante quando o método de estudos de casos relaciona-se a questões ainda não muito definidas nas discussões teóricas. Sabe-se que a Economia de Custos de Transação é uma teoria relativamente recente e oferece, ainda, pequeno arcabouço teórico relativo à possibilidade de quantificação de vários de seus parâmetros, uma vez que seus atributos não são facilmente observáveis.

Assim, os dados centrais foram obtidos por meio dos estudos de casos, pesquisas literárias e Internet, além de entrevistas pessoais, o que reforça o aspecto qualitativo da pesquisa. Não se pretende realizar inferências estatísticas para se testar as hipóteses, mas, sim, obter generalizações analíticas que possam contribuir para o referencial teórico da ECT. Pretende-se adotar o modelo da indução, no qual as conclusões são obtidas a partir de evidências empíricas de fatos particulares, de tal forma que do particular se retorna às teorias e às hipóteses (Machado, 2000) ${ }^{29}$.

Assim, a seqüência deste trabalho se inicia com a discussão dos pressupostos teóricos, referentes aos processos de coordenação dos SAGs; como metodologia de análise, busca-se demonstrar aqueles conceitos por meio da

\footnotetext{
${ }^{29}$ No modelo dedutivo, ao contrário, o movimento é inverso, do geral para o particular. As conclusões são traçadas através do raciocínio lógico, aceitando ou rejeitando hipóteses já consagradas pela teoria (Machado, 2000).
} 
metodologia de análise, busca-se demonstrar aqueles conceitos por meio da avaliação dos estudos empíricos e estratégias observadas pelas empresas. Ao final, confrontam-se os aspectos teóricos com os aspectos práticos analisados. A Figura 10 representa esse ciclo de aprendizagem entre o conceitual e o empírico.

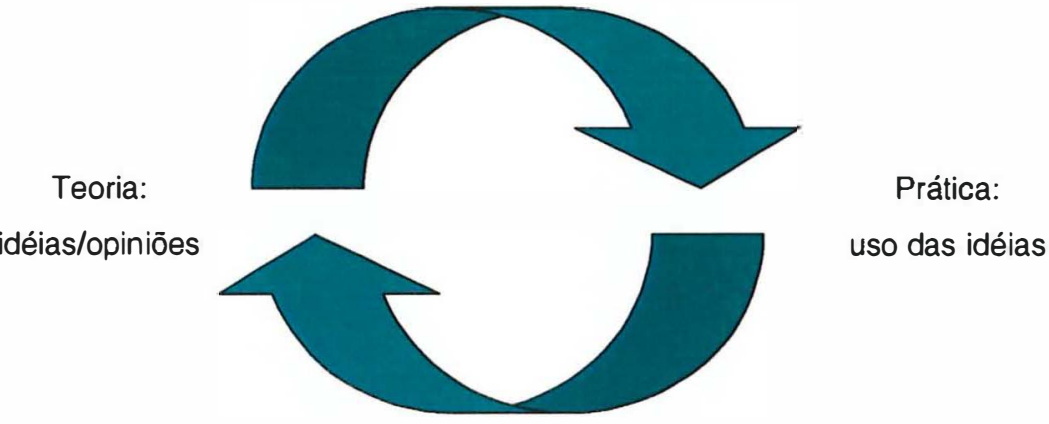

Fonte: Machado (2000:10), adaptado de Checkland e Holwell (1998)

Figura 10.0 ciclo entre a teoria e a prática.

Os estudos tiveram como objetivo a identificação das variáveis que impõem determinados custos aos agentes durante a transação e as estratégias empresariais que minimizam esses custos. Aspectos relacionados às ações coletivas e bens públicos também foram explorados. As entrevistas pessoais e de caráter exploratório, quando necessárias, foram conduzidas com base na aplicação de um questionário estruturado (ver Apêndice), permitindo respostas abertas para uma melhor avaliação do fato.

Os seguintes parâmetros foram analisados para cada um dos casos: 
1. Descrição do caso (características da transação e do produto) e estrutura de governança observada

2. Custos de transação envolvidos

2.1. Custos de informação:

a) Seleção de produtores

b) Formação de preços

2.2. Custos de negociação:

a) Custos de reconversão e operacionalização do sistema de PI

b) Custos de tecnologia de produção e acondicionamento

c) Custos do desenho do contrato

2.3. Custos de monitoramento

a) Padronização e classificação (aparato institucional)

b) Assimetria informacional (certificação e rastreabilidade)

3. Identificação dos aspectos centrais da análise sob a ótica do trabalho

Para cada situação de preservação de identidade, foram identificados os principais custos das transações associados às características das transações e dos atributos dos produtos. Com isso, e a partir do enfoque teórico, pretendese sistematizar as estratégias das empresas que minimizam esses custos e falhas. A Figura 11 sistematiza esse modelo conceitual de relações. 


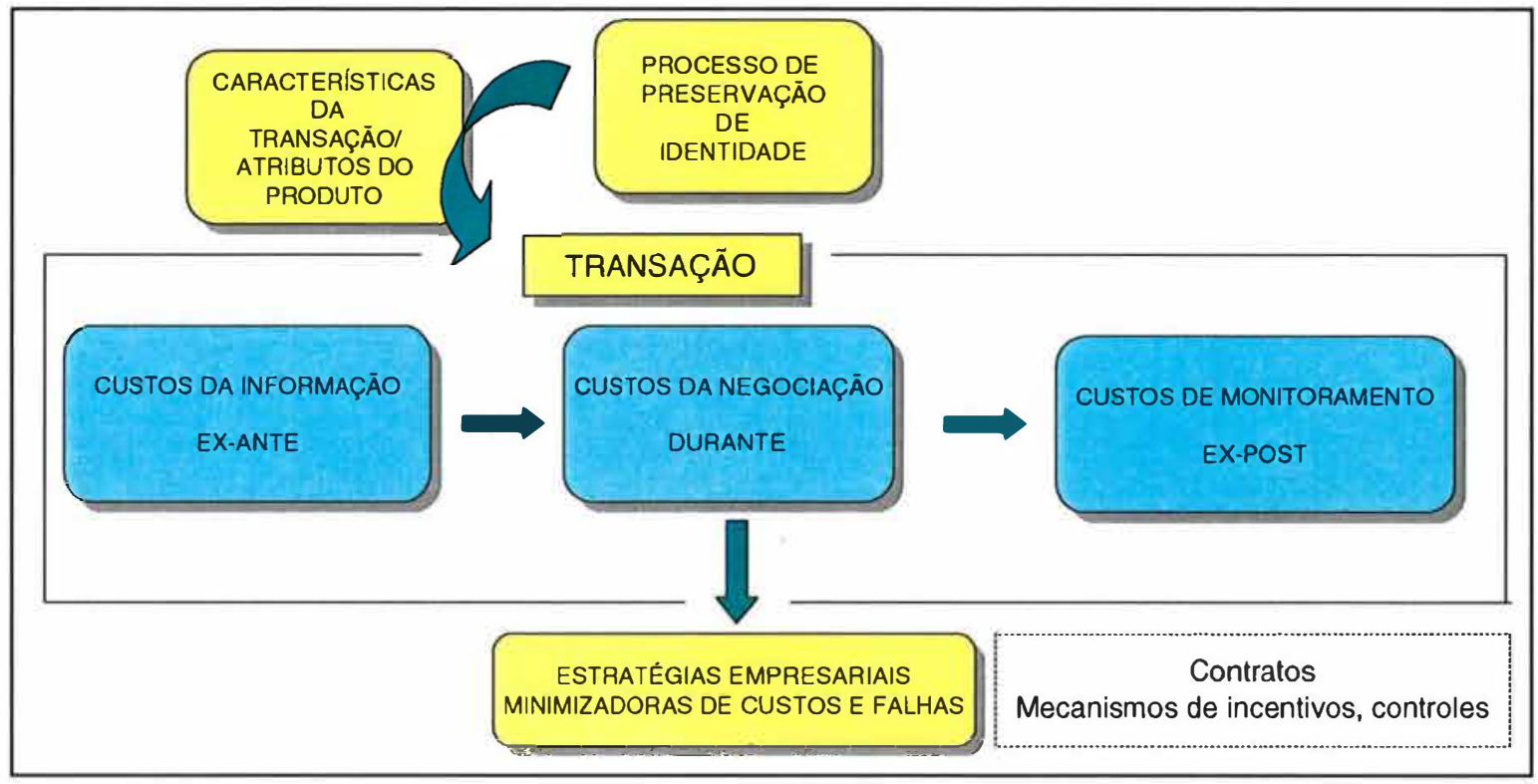

Fonte: elaborado pelo autor

Figura 11. Modelo utilizado para a sistematização da pesquisa.

Para tanto, foram selecionados estudos de casos de SAGs de grãos que apresentavam a necessidade de PI ao longo da cadeia produtiva. Os casos analisados foram selecionados segundo as características das transações entre produtor e agroindústria e dos produtos envolvidos.

Optou-se por apresentar cinco casos de empresas, relacionados aos seguintes produtos:

- soja orgânica;

- cafés especiais;

- milho ceroso (ou waxy);

- grãos com elevado teor de óleo e, por último,

- produtos transgênicos.

Os critérios que nortearam essa seleção foram basicamente dois: i) diversidade 
dos atributos das transações entre os casos, e ii) acessibilidade às informações das estratégias das empresas:

i) O atendimento ao primeiro critério - diversidade dos atributos - tem como objetivo uma aplicação mais ampla do referencial teórico, possibilitando avaliar melhor as estratégias empresariais utilizadas para distintas situações de custos de transação. Espera-se que diferentes atributos nas transações e nos produtos envolvidos requeiram distintos arranjos contratuais e aparatos institucionais.

Com a análise desses cinco casos, não se pretende, logicamente, chegar a generalizações estatísticas, dado o pequeno tamanho da amostra, mas buscar, fundamentalmente, generalizações analíticas para os aspectos teóricos abordados nos capitulos dois e três.

Assim, o primeiro caso estudado será o da soja orgânica, produto basicamente destinado ao consumo humano. Seu principal atributo - a não utilização de produtos químicos na sua produção - não é uma característica visivel ou tangivel pelo consumidor final, mas terá que ser "percebida" por ele. Os custos de produção e acondicionamento mais elevados do que os da forma tradicional têm que ser adequadamente remunerados e, nesse sentido, a empresa precisa criar mecanismos que gerem elevado grau de credibilidade ao sistema, como os processos de certificação discutidos no capítulo anterior.

O segundo caso, o de cafés especiais, refere-se ao produto que se destina à formação de blends para a elaboração de café de qualidade superior. Diminui a assimetria informacional entre produção agrícola e consumidor final em relação ao primeiro caso, já que este último pode perceber atributos de aroma e sabor superiores. Dada a grande variação de qualidade no produto agrícola café, testes de qualidade devem ser feitos a cada amostragem e devem ser gerados incentivos para manejos adequados nos cafezais. Concursos de qualidade e pagamento de prêmios são algumas das estratégias dessas empresas para garantir o produto requerido. 
O terceiro caso estudado é o do milho ceroso - ou waxy -, destinado ao consumo industrial na produção de amidos modificados. Apresenta um atributo de diferenciação em relação ao milho comum mais facilmente perceptivel por métodos de deteç̧ão rápidos e simples ou, até mesmo a olho nu, dispensando rígidos mecanismos de controle. A necessidade de volumes suficientes para a produção industrial, no entanto, implica a necessidade de desenvolvimento de contratos entre indústria e produtores e incentivos para a sua produção. A falta de uma padronização oficial para este produto também reforça a necessidade de estabelecimento de contratos particulares.

O quarto caso, o de grãos com alto teor de óleo, caracteriza-se por apresentar um atributo com maior rendimento industrial e conversão alimentar na ração animal. Com um teor de óleo duas vezes maior que o milho comum, o produto tem sido uma atrativa matéria-prima principalmente para o setor avícola nos EUA. Uma característica interessante deste caso refere-se à estratégia de busca e seleção de produtores desenvolvida a partir da criação de uma rede via Internet -, permitindo a identificação de produtores e consumidores interessados no produto ao longo de uma vasta região nos EUA de forma rápida e de baixo custo para empresas e demandantes do produto.

Finalmente, o último caso refere-se ao processo de certificação para produtos não transgênicos. Trata-se de um produto não tangivel, com forte resistência ao consumo, principalmente nos países europeus. As empresas podem oferecer serviços distintos - como certificação relacionada tanto ao processo como ao produto - segundo as necessidades de cada cliente e as características da transação. A incerteza quanto aos rumos da aceitação da biotecnologia e sua aceitação junto ao mercado consumidor também gera importante nível de risco às estratégias adotadas pelas empresas certificadoras e clientes potenciais. 
ii) Atendendo ao segundo critério - acessibilidade às informações -, optou-se por apresentar o estudo das seguintes empresas:

- Terra Preservada (soja orgânica),

- Illycaffè (cafés especiais),

- Corn Products do Brasil (milho waxy ou ceroso),

- Du Pont/Pioneer (soja e milho com alto teor de óleo) e, finalmente,

- Genetic ID (grãos transgênicos).

Os dois primeiros e o último caso foram objetos de estudo apresentados no Seminário Internacional do Pensa (Programa de Estudos de Negócios dos Sistemas Agroindustriais, da USP), respectivamente, nos anos de 1999, 1993 e 2000. Os dois outros serão descritos utilizando-se a bibliografia disponivel e informações das empresas. Todos os casos, no entanto, foram retrabalhados e os pontos não suficientemente explorados nos estudos foram contemplados e aprofundados com novas coletas de dados e informações complementadas por meio de entrevistas com diretores de algumas dessas empresas. 
5 ESTUDOS EMPÍRICOS 


\section{ESTUDOS EMPÍRICOS}

Identificados os parâmetros de custos de transação relevantes - descritos no capítulo 3 - que são aqueles associados a informação, negociação e monitoramento -, o que se pretende, neste capítulo, é avaliar a sua importância em cada um dos casos apresentados, dadas as características das transações envolvidas. Inicialmente, será apresentada uma breve descrição do caso, apresentando a estrutura de governança observada entre produtor e agroindústria. Em seguida, serão avaliados os aspectos relevantes para a coordenação do sistema - relacionados aos mecanismos de incentivos e controle. Finalmente, serão sintetizados os principais aspectos, sob a ótica da presente análise.

Serão analisadas as empresas Terra Preservada (soja orgânica), Illycaffè (cafés especiais), Corn Products do Brasil (milho waxy ou ceroso), Du PontPioneer (grãos com alto teor de óleo) e Genetic ID (grãos transgênicos). 


\title{
5.1 Terra preservada (soja orgânica) ${ }^{30}$ :
}

\begin{abstract}
"A Terra Presenvada não busca simplesmente produtores de soja sem veneno, mas produtores orgânicos que se viabilizem construindo uma relação duradoura com os consumidores".
\end{abstract}

Rogério Konzen, presidente da Terra Preservada

\subsubsection{Descrição do caso}

A Terra Preservada é uma empresa que comercializa produtos orgânicos ${ }^{31}$, com ênfase no produto soja para exportação. Localizada na região Sudoeste do Paraná, desenvolve contratos de fornecimento de soja com cerca de quinhentos produtores rurais, em sua maioria, de mini e pequeno portes.

Deve-se destacar o papel da coordenação desenvolvido pela empresa, fundamental neste Sub-SAG para a garantia da qualidade do produto e do processo produtivo. Envolve todas as atividades, desde a fabricação de insumos, multiplicação de sementes, produção rural e transporte até os armazéns. Nesse sentido, Nunes \& Sousa (1999:6) destacam que "somente quando todos atuam de maneira harmônica, o produto final atende aos requisitos do consumidor. Basta, porém, que qualquer um dos agentes envolvidos na produção e na comercialização não cumpra adequadamente seu papel para que o produto obtido não tenha as qualidades pelas quais o consumidor está disposto a pagar. O exportador da soja orgânica é responsável diante do importador por efeitos de ações de outros agentes do sub-sistema agroindustrial, sobretudo do produtor rural".

\footnotetext{
${ }^{30}$ Esta análise baseia-se no estudo de caso apresentado no IX Seminário Internacional PENSA de Agribusiness, desenvolvido por Nunes \& Sousa (1999) e entrevistas pessoais com o Sr. Rogério Konzen, diretor-presidente da empresa.

${ }^{31}$ De forma simplificada, produto orgânico pode ser entendido como aquele que, ao longo do seu processo produtivo, não teve contato com defensivos químicos tóxicos nem fertilizantes altamente solúveis.
} 
5.1.2 Formas de coordenação e de incentivos associadas aos custos de transação

a) Custos da informação

\section{- Busca/seleção de Produtores}

Somente a soja produzida por produtores cadastrados é adquirida pela Terra Preservada. O produtor rural envolvido no projeto assina um contrato, no qual se compromete a produzir de acordo com as diretrizes do Instituto Biodinâmico e a comunicar, imediatamente, à Terra Preservada caso seja necessário utilizar práticas não recomendadas. O cadastro do produtor orgânico contém informações pormenorizadas sobre o estabelecimento e o uso do solo. Para divulgar o projeto e atrair novos produtores, a Terra Preservada possui um programa semanal na rádio local, com duração de quinze minutos, aos sábados. Além disso são veiculadas várias chamadas curtas diárias, aproximadamente seis por dia. Esse meio de comunicação é importante para a divulgação do projeto e, consequentemente, para a cooptação de novos produtores.

Outra forma de busca - e de pré-seleção - refere-se às palestras apresentadas por representantes da empresa visando à conscientização ecológica de produtores.

\section{- Formação do preço}

O preço referência utilizado nos contratos é o de mercado, acrescido de um prêmio móvel, segundo características do produto e do processo de produção. A grande liqüidez do mercado da soja, além de sua grande transparência, permite uma informação rápida e de baixo custo a produtores e à Terra Preservada. 


\section{b) Custos da negociação}

- Custos de reconversão produtiva/ tecnologia de produção e acondicionamento

A produção da soja orgânica requer uma série de cuidados especiais ao longo de todo o processo produtivo.

O produtor rural deve abrir mão de práticas comuns da agricultura moderna, como o uso de fertilizantes prontamente solúveis e produtos químicos que controlam a incidência de pragas e doenças. Esses produtos passam a ser substituídos por fertilizantes naturais, com resposta mais lenta na liberação de nutrientes e pelos chamados inseticidas biológicos. Um outro custo adicional refere-se à limitação produtiva das atuais variedades de sementes utilizadas pela empresa, que devem apresentar atributos não comumente valorizados na soja commodity, como características de coloração e organolépticas.

Nesse sentido, a assistência técnica fornecida pela empresa passa a ser uma peça fundamental do sistema, na redução de custos ao produtor. Ela é, a um só tempo, um bem (privado) em cujo provimento o mercado falha (pois a orientação é específica para a produção orgânica), um incentivo para o produtor (que obtém o serviço por um preço inferior ao custo de mercado) e um instrumento de monitoramento (nas visitas, o agrônomo verifica a observância às normas de produção orgânica).

Acondicionamento e transporte são, também, elementos vitais na coordenação do sistema. A recepção e o acondicionamento do grão, feita em sacas de 1.000 $\mathrm{kg}$ identificadas por produtor, foram desenhados de forma a permitir a rastreabilidade do produto: caso se constate, em qualquer momento, produto fora das especificações, é possivel identificar a origem do problema.

No transporte do estabelecimento rural até as unidades de recepção, exige-se que os caminhões sejam cuidadosamente varridos, a fim de não contaminar a 
soja orgânica com grãos remanescentes de cargas anteriores, que podem conter resíduos de agrotóxicos e de fertilizantes solúveis.

- Custos do desenho/renegociação dos contratos

A classificação do grão é feita no momento da chegada de todos os caminhões e é necessária para a remuneração diferenciada, que constitui o principal incentivo para o produtor. Deve-se destacar que a simples utilização das práticas exigidas pela empresa não garante ao produtor o recebimento do prêmio, o que pode gerar custos adicionais para o desenho e renegociação de contratos. A ocorrência de chuvas durante a colheita, por exemplo, pode ocasionar alteração na coloração do grão, o que o desclassificaria o produto para a alimentação humana (a exemplo do leite de soja e derivados, como o tofu, espécie de queijo à base de soja), o que gera um elevado grau de incerteza para vendedor.

A remuneração do produtor obedece a uma escala de prêmios que constitui o principal incentivo para o produtor orgânico. O valor efetivamente recebido pelo produtor é uma média ponderada que reflete a composição do produto entregue: os grãos avariados, ardidos e quebrados são adquiridos pelo preço da soja "comercial", sem prêmio; a parte remanescente recebe o prêmio correspondente à categoria em que se enquadra. A escala de remuneração não apenas incentiva o cumprimento das diretrizes da agricultura orgânica (qualidade do processo), como, também, induz o produtor a ter cuidados que evitem características indesejáveis do grão (qualidade do produto).

O Quadro 9 apresenta os prêmios médios oferecidos, segundo a categoria do produtor. Na primeira safra após a adesão à produção orgânica, ele se enquadra na categoria "em conversão". Na medida em que mantém as práticas propostas pela Terra Preservada - e atingida a qualidade requerida -, os 
prêmios tornam-se crescentes como forma de estimular o produtor a se manter nessa modalidade de produção.

\begin{tabular}{|l|l|l|}
\hline Categorias & Características & $\begin{array}{l}\text { Prêmio sobre a soja } \\
\text { comercial (R\$/sc) }\end{array}$ \\
\hline Comercial & $\begin{array}{l}\text { Grãos quebrados, avariados e ardidos, } \\
\text { com destino para a produção de ração } \\
\text { orgânica }\end{array}$ & Não há \\
\hline Conversão & $\begin{array}{l}\text { Colheita do produto semeado em terra } \\
\text { há 12 meses sem uso de agroquímicos }\end{array}$ & $\begin{array}{l}\mathrm{R} \$ 3,00 \text { (ágio em } \\
\text { torno de 22\%) }\end{array}$ \\
\hline Orgânica & $\begin{array}{l}\text { Colheita do produto semeado em terra } \\
\text { há 24 meses sem uso de agroquímicos }\end{array}$ & $\begin{array}{l}\mathrm{R} \$ 4,50 \text { (ágio em } \\
\text { torno de 32\%) }\end{array}$ \\
\hline $\begin{array}{l}100 \% \\
\text { orgânica }\end{array}$ & $\begin{array}{l}\text { Propriedade que adota técnicas } \\
\text { orgânicas para todas as atividades de } \\
\text { produção agropecuária }\end{array}$ & $\begin{array}{l}\mathrm{R} \$ \text { 6,00 ágio em } \\
\text { torno de 42\%) }\end{array}$ \\
\hline
\end{tabular}

* Ágios calculados sobre o preço médio do início da safra 98/99

Quadro 9. Prêmios pagos pela Terra Preservada para a soja orgânica, em $\mathrm{R} \$ / \mathrm{saca}$ de $60 \mathrm{~kg}$, segundo a categoria do produtor.

Outros incentivos, que surgem como resposta aos custos acima descritos são o fornecimento de insumos e o desenvolvimento de tecnologia, buscando a diminuição de custos associados à produção. Assim, a Terra Preservada fornece os insumos permitidos pela regulamentação privada (segundo normas do Instituto Biodinâmico - IBD) da agricultura orgânica, principalmente fertilizantes de baixa solubilidade e defensivos biológicos. A empresa participa, também, de esforços voltados à adequação de produtos defensivos, fertilizantes orgânicos e variedades de sementes adaptadas às características dos estabelecimentos agropecuários envolvidos e ao meio-ambiente. 
c) Custos de monitoramento/controle

No mercado tradicional de commodities, os atributos relevantes das mercadorias são razoavelmente conhecidos por compradores e vendedores. No caso dos produtos orgânicos, vendedores e compradores têm acesso diferenciado a informações sobre o processo produtivo e sobre a manipulação do produto

Dadas essas características, torna-se necessária a contratação de uma terceira parte - no caso, uma certificadora com credibilidade internacional - para diminuir essa assimetria. Assim, o IBD acompanha todo o processo produtivo e, para cada exportação, emite um selo, reconhecido pela IFOAM, que garante que o produto atende às normas requeridas pelo consumidor.

Há, também, o controle de qualidade do produto - análise de resíduos em amostras coletadas aleatoriamente a cada 12 contêineres. Constatada alguma irregularidade, é possivel identificar o produtor responsável, já que os lotes são acondicionados em sacas de 1 tonelada e identificados. Além disso, são mantidas amostras da soja recolhidas no ato da entrega às centrais de recepção. Esse processo constitui-se na rastreabilidade do produto e é necessária para coibir eventuais práticas oportunistas por parte do produtor e para identificar problemas (contaminação, manejo incorreto). Essa medida, além de coibir este tipo de ação, permite a identificação e eventual penalização judicial dos responsáveis por contaminações.

\subsubsection{Aspectos centrais da análise}

Os aspectos mais relevantes deste caso da empresa Terra Preservada, sob a ótica da presente análise são os seguintes: 
- A seleção de produtores é feita regionalmente atingindo basicamente pequenos produtores. Dias de campo e anúncios em rádio são práticas suficientes para atingir essa população. Uma característica desejável é a conscientização ecológica dos produtores, estimulada por meio de palestras periódicas patrocinadas pela Terra Preservada.

- Incentivos pecuniários progressivos, como forma de estímulo à manutenção da atividade, dados os elevados custos de reconversão e aumento progressivo e lento da produtividade.

- Elevada assimetria informacional: necessidade de monitoramento, certificação e rastreabilidade. Os dois primeiros são realizados por empresa certificadora com grande credibilidade internacional e a certificação é feita sobre o processo. A rastreabilidade, apesar de seu custo, tem como principais objetivos coibir ações oportunísticas e permitir a responsabilização judicial, no caso de contaminações. Essa rastreabilidade é facilitada pela verticalização da empresa, que exerce as diversas atividades que englobam o recebimento, ensacamento e a distribuição do produto até o porto. 


\subsection{Illycaffè ${ }^{32}$ :}

"A missão da empresa é estimular, guiar e satisfazer as demandas de consumidores por cafés expressos de alta qualidade, por meio do suprimento do produto e serviços necessários para sua transformação. Esta missão tenta ser atingida por meio da paixão pela qualidade, desejo de pagar por qualidade, habilidade para passar esta qualidade ao consumidor e prioridade no elemento hedonístico do consumo de café, e não no aspecto fisiológico".

Ernesto Illy, presidente da Illycaffè.

\subsubsection{Descrição do caso}

A Illycaffè, empresa italiana fornecedora de cafés finos, desenvolveu um processo de coordenação com reconhecida eficiência. Planejou estratégias de suprimento e distribuição, de forma a manter um padrão de qualidade muito superior à das demais empresas torrefadoras de café. Zylbersztajn \& Neves (1997) descrevem a estratégia adotada pela empresa, que mantém fortes vínculos tanto a jusante - permitindo grande identidade e relação de fidelidade entre o cliente e a marca - quanto a montante, desenvolvendo formas de estímulo e controle próprios para a aquisição de produtos dentro do padrão desejado. Para garantir a qualidade requerida pela marca, a lllycaffè criou um sistema de sinalização de preços para o produtor, estimulando-o a produzir os atributos de qualidade demandados por meio de prêmios atrativos na remuneração. Nessa mesma linha, estabeleceu também uma premiação para

\footnotetext{
${ }^{32}$ Esta análise baseia-se no estudo de caso apresentado no IIl Seminário Internacional PENSA de Agribusiness, desenvolvido por Zylbersztajn \& Neves, revisitado em Zylbersztajn \& Neves (1997) e entrevistas pessoais com o Sr. Aldir Alves Teixeira, diretor de qualidade da Illycaffè.
} 
os produtores mais bem classificados em um concurso anual.

5.2.2 Formas de coordenação e de incentivos associadas aos custos de transação

a) Custos da informação

- Busca/seleção de Produtores

Inicialmente, deve-se destacar que a Illycaffè é reconhecida pela sua rigidez na aferição da qualidade do café utilizado como matéria-prima. O produto final da empresa resulta de uma mistura, ou blend, composto por diversos tipos de café, originados em países distintos, como a Colômbia ou regiões da África. O café brasileiro confere algumas condições consideradas insubstituíveis para esse blend - como a possibilidade da secagem no terreiro - e corresponde a cerca de $55 \%$ a $60 \%$ do volume total processado pela empresa.

Duas variáveis são responsáveis diretamente pela qualidade do café produzido: as condições edafo-climáticas da região produtora e o manejo adequado especialmente correção e fertilidade dos solos. Nesse sentido, a região dos cerrados brasileiros tem-se destacado pelas sua altitude, baixa pluviosidade na colheita e solos de alta qualidade para a produção de café.

Os tratos culturais, por sua vez, resultam diretamente dos estímulos aos produtores. O concurso promovido pela Illycaffè teve grande importância como incentivo e alterou substancialmente o padrão e o valor do café originado nos cerrados. Esse concurso anual, iniciado no começo da década de 90, premia os 10 produtores mais bem classificados, em função de sua qualidade. Além das premiações em dinheiro, há o reconhecimento da classe produtora e industrial. Não por acaso a grande maioria dos premiados tem sido da região dos cerrados. 
O concurso possibilita, também, a identificação de produtores preocupados com alta qualidade, facilitando o processo de seleção, permitindo, inclusive, um amplo cadastro de produtores, com informações específicas sobre a evolução de sua produção. Mais do que isso, Zylbersztajn \& Neves (1997, p. 57) sugerem que o concurso "introduziu um sistema de feed-back de informações para o produtor, que pode entender quais os aspectos a serem melhorados no seu produto para atingir o padrão desejado. Perceba-se que no sistema tradicional de comercialização o produto é descaracterizado assim que deixa a propriedade, inviabilizando qualquer retorno de informações". A Illycaffè criou uma sinalização de preços e qualidade para o produtor, que passou a produzir os atributos demandados por empresas de cafés diferenciados.

Paralelamente, a empresa desenvolve também um trabalho de difusão de tecnologia junto aos produtores de café de regiões de boa bebida, informando sobre as ações necessárias para a obtenção de frutos de boa qualidade.

Assim, a concentração geográfica e a consolidação do concurso representa um importante redutor no custo de transação de busca e seleção de produtores.

\section{- Formação do preço}

Os preços são referenciados nas cotações do mercado spot, ou físico, que são bem sinalizados nas regiões produtoras. A Bolsa de Mercadorias e Futuros BM\&F, de São Paulo, apresenta uma alta liquidez para os contratos de café, o que contribui para a redução dos custos da obtenção da informação de preços $^{33}$.

\footnotetext{
${ }^{33}$ Apenas para se ter uma idéia da liquidez desses contratos, em 1999 foram negociados 39 milhões de sacas de café na BM\&F, ou cerca de 1,5 vez a produção total de café brasileira daquele ano.
} 
b) Custos da negociação

- Custos de reconversão produtiva/ tecnologia de produção e acondicionamento

Não há, a principio, custos adicionais significativos em relação àqueles já desenvolvidos por produtores de alto nivel tecnológico. O manejo adequado, porém, não é suficiente para garantir a comercialização com a empresa, visto que a qualidade também dependerá de outros fatores, como os climáticos.

Alguns investimentos específicos a jusante podem ser realizados para uma maior valorização do café, a exemplo daqueles desenvolvidos pela Associação dos Produtores da Região de Patrocínio (ACARPA), que passou a organizar o re-beneficiamento do produto e articulou-se com a Rede Ferroviária e Cia. Docas visando à adequação de vagões e armazéns especificos para cafés de alta qualidade.

- Custos do desenho/renegociação dos contratos

Via de regra, a empresa não estabelece contratos formais com os produtores. Há apenas uma sinalização de compra dos produtos de alta qualidade, oferecendo um prêmio de até $30 \%$ acima dos preços praticados no mercado. A instabilidade na qualidade do produto, a forte volatilidade das cotações no mercado spot e especificidades vinculadas a cada operação - como a necessidade de determinados tipos de produto para a formação de blends são razões apontadas pela empresa para o não estabelecimento de contratos de longo prazo. Há, no entanto, o estabelecimento de contratos na busca de estreitamento de vínculos e divisão de responsabilidade com os segmentos a jusante, como o fornecedor de máquinas de fazer café e os coffee shops. 


\section{c) Custos de monitoramento/controle}

A Illycaffè desenvolveu um sistema de controle de qualidade bastante rígido, orientando-se por padrões técnicos bem superiores aos dos demais compradores. O sistema de aquisição inicia-se com a coleta de amostra realizada pela empresa Porto de Santos, com quem a lllycaffè mantém contrato de parceria no Brasil. Antes da negociação, amostras são enviadas simultaneamente para o laboratório de São Paulo e de Trieste na Itália. Somente após as análises e o cruzamento dos resultados, é que são determinados a ordem de compra e o ágio a ser pago. Esse prêmio, cujos parâmetros são variáveis e dependem de negociação direta entre produtor e a própria Illy, tem correspondido a valores que variam entre 5 e $30 \%$ sobre os preços do café de boa e mesmo de excelente qualidade ${ }^{34}$.

Como reflexo direto da ação da lllycaffè, consolidou-se a conscientização dos produtores e torrefadoras quanto à qualidade superior do café da região dos cerrados. Associações foram desenvolvidas com o objetivo de organizar a representatividade dos produtores da região, demarcar uma região de origem controlada, controlar a qualidade com padronização, selo de qualidade do produto, certificado de origem e prestação de serviços, que vão desde a padronização até embarque e transporte. Além disso, as associações buscam estabelecer convênios e realizar o marketing comercial e institucional.

Há um beneficio tanto para os produtores, que valorizam seu produto, quanto para a própria Illycaffè, que também se beneficia pelo aumento da qualidade média do café na região, gerado pelos incentivos e controles desenvolvidos pelas associações regionais.

\footnotetext{
${ }^{34}$ Segundo informações da empresa, a inexistência de intermediários facilita o processo de negociação entre as partes, mesmo sem a definição de parâmetros quantitativos ex-ante para o estabelecimento do prêmio.
} 


\subsubsection{Aspectos centrais da análise}

Os aspectos mais relevantes deste caso da lllycaffè, sob a ótica da presente análise são os seguintes:

- Controle da qualidade e possibilidade de feed-back da informação: essa característica gera um benefício mútuo: ao produtor, a informação sobre as deficiências de seu produto, permitindo a sua melhoria, a partir da sinalização clara dos atributos desejáveis; ao comprador, o aumento da qualidade média do produto.

- Incentivos financeiro e via concurso: essa última estratégia, a realização de concursos, permite que seja elaborado um cadastramento anual de produtores, com informações sobre o seu nível técnico e evolução da qualidade do seu produto. As associações exercem papel importante no processo da melhoria da qualidade, pelo desenvolvimento e emissão de selos de qualidade e certificados de origem.

- Atributo do produto percebido pelo consumidor na forma de aroma e sabor diferenciados: empresa desenvolve reputação junto ao consumidor, principalmente por meio de estratégias de marketing (café superior e xícara diferenciada, criando o apelo da xícara como a "embalagem do produto"). 


\subsection{Corn Products (milho waxy ou ceroso) ${ }^{35}$ :}

\subsubsection{Descrição do caso}

O milho waxy (ou ceroso) distingue-se do milho commodity, tanto pelas suas características químicas quanto físicas. Assim, enquanto o milho regular apresenta um teor de amilose de $28 \%$ e amilopectina de $72 \%$, o milho waxy apresenta, respectivamente, $0 \%$ e 100\%. Quanto aos aspectos físicos, suas principais caracteristicas são as seguintes: produz pastas de amido claras que não gelificam nem sedimentam, não tem cheiro acentuado, exige menos aquecimento para empastar, apresenta grande inchamento em água quente e retém firmemente toda a água absorvida.

Essas características conferem à produção de amidos modificados uma significativa diferenciação em relação ao amido commodity e é sob essa forma que a Corn Products comercializa seus produtos à base de milho waxy. Essa matéria-prima tem tido uma larga aceitação para a produção de baby-food (permitindo melhor aparência e maior uniformidade), além de usos diversos, a exemplo da produção de papel, tecidos e adesivos, entre outros. Seu mercado consumidor principal é o externo (Japão, EUA e Europa).

Assim, Sousa et al. (1998) descreveram o caso do milho waxy como um outro exemplo de SAG estritamente coordenado por contratos idiossincráticos. Como não há um mercado que garanta classificação do produto e liquidez para compradores e ofertantes, estabelece-se uma relação de dependência mútua entre produtor de milho waxy e a agroindústria produtora de amilopectina ou de amidos modificados. A estrutura de governança adotada pelas partes é um

\footnotetext{
${ }^{35}$ Esta análise baseia-se em revisão bibliográfica sobre o tema e entrevistas pessoais com o Sr. Katuyuki Kinoshita, gerente responsável pela qualidade da fábrica e pelo programa de desenvolvimento de milho waxy na Corn Products do Brasil.
} 
contrato que garante a compra do produto, assim como a remuneração dos gastos em isolamento de área, estrutura de armazenagem dedicada, assistência técnica e controle varietal. A empresa demandante - Corn Products - oferece as sementes, garantia de compra e uma bonificação em espécie sobre um preço referência, para produtos dentro da especificação desejada (Dijkstra, 1997).

5.3.2 Formas de coordenação e de incentivos associadas aos custos de transação

a) Custos da informação

- Busca/seleção de Produtores

O volume atualmente produzido é de 30.000 toneladas, mediante contratos com cerca de 200 produtores.

O critério de seleção de produtores está fortemente condicionado a duas variáveis: à possibilidade de se segregar o produto e à garantia de um volume mínimo necessário. Assim, a região produtora selecionada, Taquarituba/SP apesar da distância de $400 \mathrm{~km}$ da fábrica, em Balsa Nova/PR - atendia àqueles dois critérios: o primeiro refere-se à existência de um armazém que ofereceu condições de segregação plena, evitando o risco de contaminação. O segundo, associado ao fato de que a região não é própria para a produção de soja, que em condições de mercado mais favorável para esta última, poderia competir pelo uso da terra.

No passado, já se chegou a fazer propaganda em rádio para fomentar a produção do milho waxy na região, mas, com a divulgação dos produtores e de um comprador que percorre as propriedades da região, já se verifica o interesse 
de os próprios produtores - antigos e novos - irem à filial da empresa na cidade para manifestar o desejo de produzir esta variedade de milho.

\section{- Formação do preço}

Dada a menor liquidez no mercado interno do milho em relação a outras commodities, como a soja ou o café, os preços referenciais para a fixação dos valores são tomados diretamente na Bolsa de Cereais de São Paulo. Sobre esse preço, descontam-se custos de fretes e soma-se um prêmio pela entrega do produto.

b) Custos da negociação

- Custos de reconversão produtiva/ tecnologia de produção e acondicionamento

Não há custos de conversão para os produtores, uma vez que as práticas culturais e técnicas de plantio são as mesmas que de outras variedades. As produtividades também são equivalentes às de milho híbrido simples produzidas na região. As únicas exigências ao produtor referem-se ao isolamento da área plantada de, pelo menos, $200 \mathrm{~m}$ de distância em relação ao plantio de um milho convencional e/ou a uma defasagem de plantio de pelo menos 20 dias.

Uma possivel diferenciação no custo de produção, em relação ao do milho regular, refere-se à possibilidade de aumento de preços da semente de milho waxy, cuja produção e comercialização restringem-se a apenas uma empresa, a Colorado (atual Dow Chemical). Até a presente safra, os preços cobrados por essa empresa à Corn Products representavam a média dos preços de mercado das variedades com produtividade compativel. Há, no entanto, uma forte 
pressão para a cobrança de um ágio em relação ao preço das demais em torno de $10 \%$. Nesse caso, mesmo havendo o repasse ao produtor, o impacto sobre o custo de produção do milho - em relação ao do milho regular - será inferior a $1 \%$, uma vez que o custo da semente representa cerca de $8 \%$ do custo de produção variável de milho, produzido com média/alta tecnologia.

Quanto aos custos de conversão do armazenador, a principal exigência é a de que não haja qualquer contaminação com outros tipos de milho (a quantidade de mistura máxima admitida é de $2 \%$ ). Um maior cuidado na operação de secagem também é exigido.

Na fábrica, o procedimento ocorre da seguinte forma: o produto (a granel) é depositado em dois silos separados e a moagem é feita ao longo do ano inteiro, durante uma semana por mês. Durante essa semana, é necessário que se promova a interrupção da moagem do milho regular e uma limpeza em toda a linha de produção, representando um acréscimo nos custos.

Após a moagem, os diferentes tipos de amidos modificados são devidamente embalados (em sacas de $20 \mathrm{~kg}$, ou conforme exigência prévia do cliente) e são embarcados, em sua maioria, em contâineres para exportação.

- Custos do desenho/renegociação dos contratos

Os contratos apresentam a duração de uma safra e a empresa fornece insumos (semente de milho waxy e fertilizantes), recebendo como pagamento, uma determinada quantidade do produto. Como forma de incentivo, o produtor recebe um prêmio de $10 \%$ em relação à cotação da Bolsa de Cereais de São Paulo, descontado o frete.

Os casos mais freqüentes de renegociação de contratos referem-se a desacordos com o preço referência tomado na Bolsa de Cereais de São Paulo, 
que pode estar sujeita a distorções em relação ao mercado de uma determinada região.

c) Custos de monitoramento/controle

A principal exigência refere-se à necessidade de segregação do produto. Contaminações acima de $2 \%$ com outras variedades de milho já desqualificam o milho ceroso. Assim, há a necessidade do acompanhamento da produção com, normalmente, duas visitas por safra - feita por um funcionário da empresa. A primeira visita é realizada durante o plantio (para se certificar de que haverá uma defasagem espacial e temporal em relação ao plantio de outras variedades) e a segunda, durante a colheita.

Para se testar a pureza, é utilizado um método de detecção bastante simplificado em amostras dos lotes de milho que chegam ao armazém. Com a adição de uma solução de iodo diluído, pode-se detectar a presença de milho regular pela sua coloração. Deve-se destacar que a despeito da facilidade e simplicidade do teste, analistas experimentados podem detectar essa contaminação somente com exame visual do produto.

Outra preocupação manifestada pela empresa refere-se à deficiência na classificação oficial de milho que, defasada, não mais atende a critérios de padrão mínimos exigidos, tanto para a agroindústria alimentícia como para a formulação de rações. Assim, para algumas características específicas, a empresa se viu forçada a desenvolver contratos particulares com produtores, estabelecendo critério de ágios e deságios, segundo uma tabela de 
classificação própria. Essa ação gera, seguramente, aumento no custo de transação na comercialização do produto ${ }^{36}$.

O consumidor industrial do amido modificado, por sua vez, percebe o produto apenas como de qualidade superior para os seus fins industriais específicos. Com o uso do amido produzido com milho ceroso, o produto final apresenta uma melhor aparência ou maior uniformidade. Para tanto, pode pagar mais por este produto. Confia na marca do produto e na reputação da empresa fornecedora, no caso, a Corn Products, a maior esmagadora brasileira de milho úmido e uma das quatro maiores empresas moageiras de milho dos EUA.

\subsubsection{Aspectos centrais da análise}

Os aspectos mais relevantes deste caso da Corn Products, sob a ótica da presente análise são os seguintes:

- Atributo facilmente detectável pelo aspecto físico e textura, diminuindo a rigidez de processos de monitoramento e controle na relação produtorindústria. Já na fase posterior da cadeia, envolvendo o primeiro processador e o segundo, as características físico/químicas diferenciadas nem sempre são facilmente detectáveis. Neste caso, prevalece a reputação da empresa junto ao seu consumidor industrial (credibilidade institucional). Deve-se destacar que este é um exemplo ilustrativo, no qual a reputação da empresa prevalece sobre a necessidade da contratação de um terceiro para certificação do produto.

\footnotetext{
${ }^{36}$ Exemplo dessa falha de mercado pode ser ilustrado pela determinação do governo de junho de 1989, que nivelou para baixo o padrão de classificação do produto, passando a vigorar apenas o padrão tipo 3 , e peneira $1 \mathrm{~mm}$, enquanto na classificação oficial de 8 de novembro de 76 (Portaria $\mathrm{n}^{\circ} 845$ ) estabelecia que o milho destinado à comercialização interna, deveria ser classificado segundo critérios mais rigidos, apesar de já defasados, conforme apresentado no item 3.2.1).
} 
- Dificuldade de obtenção do produto no mercado exige o estabelecimento de contratos: a alta especificidade do produto sugere essa forma de governança, de modo a garantir, de um lado, o suprimento ao comprador e, de outro, a comercialização ao produtor rural.

- Os incentivos não são muito altos, compatíveis com os baixos custos de reconversão dos produtores (ágio de $10 \%$ e financiamento de sementes e fertilizantes). 


\subsection{Du Pont/Pioneer (milho High Oil) ${ }^{37}$}

\subsubsection{Descrição do caso}

Este programa resultou da associação entre as empresas Du Pont e Pioneer e na constituição do programa "Optimum Quality Grains" que estabelece uma rede de empresas para comercialização de produtos diferenciados, como o milho com alto teor de óleo ${ }^{38}$.

O high oil corn (HOC) contém de 6 a $8 \%$ de óleo, enquanto o milho tradicional apresenta uma média de $3,5 \%$. Segundo Brown et al. (1999), a produção deste tipo de milho tem crescido significativamente. Em 1995, o primeiro ano de produção comercial deste produto, 170.000 acres foram plantados nos EUA. Em 1999, a área estimada cresceu para 2 milhões de acres, sendo que $25 \%$ referem-se ao produto da Optimum. Os principais demandantes têm sido as empresas de rações para aves e suínos. Segundo o autor, estima-se que o acréscimo do valor deste milho para os produtores de aves varie desde US $\$$ 0,20/bushel, para um percentual de óleo de $5,0 \%$ até US $\$ 0,36 /$ bushel para um teor de óleo de 7,5\%. Em menor escala, também tem sido utilizado para fins alimentícios e industriais. Deve-se ressaltar que os prêmios recebidos pelo produtor na comercialização são proporcionais ao teor de óleo do produto entregue.

\footnotetext{
${ }^{37}$ Esta análise baseia-se em revisão bibliográfica sobre o tema, pesquisas na Internet e contato pessoal durante o VI World Soybean Research Conference, realizado em agosto de 1999, em Chicago/EUA, e via e-mail, com o Sr. David Young, diretor de negócios da Du Pont norte-americana.

${ }^{38}$ Estes produtos e serviços ainda não estão sendo oferecidos no Brasil. As avaliações referem-se ao sistema norte-americano.
} 
5.4.2 Formas de coordenação e de incentivos associadas aos custos de transação

a) Custos da informação

- Busca/seleção de Produtores

Umas das dificuldades da atividade agrícola diz respeito às distâncias geográficas e este caso exemplifica como a Internet pode representar um importante redutor de custos de transação (no processo de localização e seleção de produtores) para empresas que pretendem estabelecer contratos envolvendo PI de grãos ou de outros produtos agrícolas.

Via internet, os contratos de produção e comercialização são divulgados e firmados, por meio do sistema denominado OSCAR (Optimum Sales Connection and Resource), desenvolvido a partir do programa Optimum Quality Grains. Por meio de seu site (www.optimumqualitygrains.com), a Optimum pode localizar produtores nas regiões de seu interesse, indicar fornecedores e locais de entrega e, até mesmo, firmar contratos de cooperação entre produtores e originadores, com critérios propostos por ela. Deve-se destacar que o site basicamente direciona esforços no desenvolvimento de novos mercados.

Em 1999, foi estabelecida uma parceria entre a Optimum Quality Grains e duas das maiores tradings internacionais, Archer Daniels \& Midland Company (ADM) e a ConAgra Trade Group, como estratégia para expandir o mercado de exportações do grão com alto teor de óleo.

Tudo isso, a um custo de transação bastante inferior àqueles tradicionalmente praticados. O Mapa 1, que se encontra disponivel na página da Internet, indica aos interessados em estabelecer contratos com a empresa, as regiões onde se aceita o recebimento do produto, conforme o destino: se para o mercado interno ou para exportação. Os contratos especificam que o Optimum e seus agentes 
têm a prerrogativa de avaliar e inspecionar as condições da cultura. Informações como manejo da cultura e formas de segregação no armazenamento e transporte, entre outras, também podem ser obtidas na referida página.

1999 OPTIMUM(B) High Oil Corn Contracting Locations

Using the OSCAR ${ }^{\mathrm{IM}}$ Contracting Resource

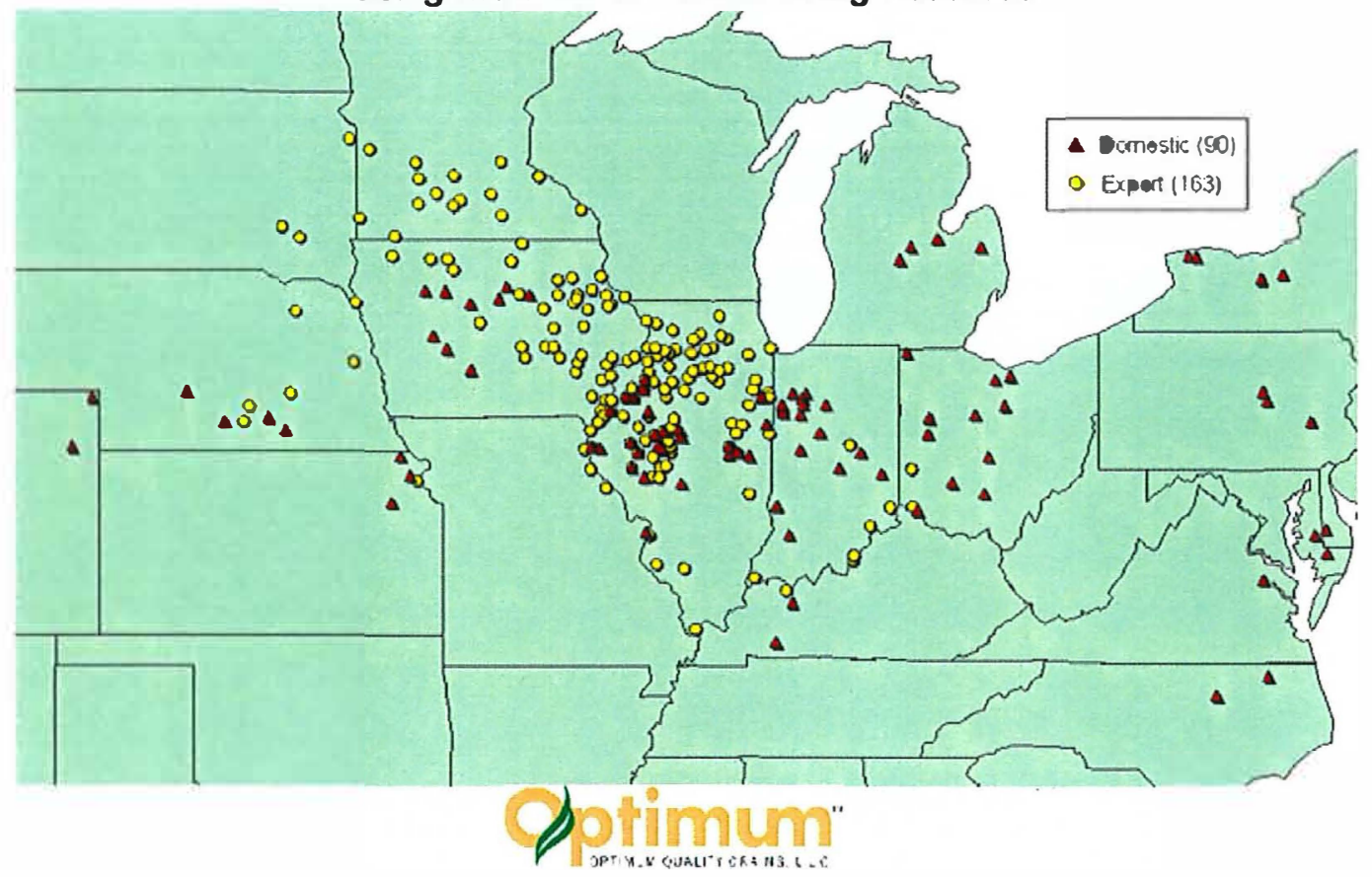

Fonte: Internet (site: wWw.optimumqualitygrains.com, jan/2000)

Mapa 1. Locais disponíveis para entrega de milho com alto teor de óleo, segundo seu destino. 


\section{- Formação do preço}

Os preços de referência são os fixados no mercado spot, dada a grande transparência do mercado de milho nos EUA, que, por sua vez, tem como grande referencial a Chicago Board of Trade - $\mathrm{CBOT}^{39}$. O pagamento será, então, baseado nas cotações negociadas nesta Bolsa para o milho amarelo tipo 2 , acrescido de um prêmio, segundo o teor de óleo do milho entregue.

b) Custos da negociação

- Custos de reconversão produtiva/ tecnologia de produção e acondicionamento

Além dos cuidados com a não contaminação do produto, não há necessidade de qualquer investimento no que diz respeito à atividade produtiva do milho com alto teor de óleo ${ }^{40}$. No entanto, Brown (1999) afirma que a utilização da semente HOC implica um aumento no custo de produção de até US\$ $44,44 /$ acre devido ao custo da semente mais elevado. Este aumento equivale a um incremento de até $7 \%$ no custo de produção.

O prêmio do produtor está condicionado à porcentagem de óleo do produto que, por sua vez, é função não só do material genético utilizado, como também do manejo agrícola (Hahn \& Schuerman, 1976). Assim, um manejo adequado pode trazer benefícios ao produtor, cujo diferencial de retorno líquido pode variar em mais de $5 \%$, quando o teor de óleo varia de 6,5 para $8,0 \%$.

No site da Optimum é proposto, também, um protocolo de rotinas que deve ser seguido por todos os agentes envolvidos. Assim, as empresas produtoras de sementes devem tomar cuidados, como a limpeza de máquinas beneficiadoras

\footnotetext{
${ }^{39}$ Cabe destacar a liquidez da CBOT. A média de contratos anuais de milho negociados nesta Bolsa representa cerca de 5 vezes a produção mundial dessa commodity.

40 Todavia, da mesma forma que o caso do milho waxy, este produto também requer a segregação em todas as fases pós-colheita, desde o transporte até a armazenagem.
} 
e rotular corretamente os sacos de sementes. Os produtores, por sua vez, devem assinar o contrato e assistir a sessões de treinamento. Além disso, comprometem-se a comprar as sementes das empresas recomendadas, limpar máquinas e equipamentos e concordar com vistorias no campo e nos equipamentos, que podem ser feitas a qualquer momento. Os armazenadores inscritos no programa devem estar habilitados para segregar o produto, com sistemas dedicados, guardar amostras de cada carregamento e também admitir inspeções de uma terceira empresa. Finalmente, os transportadores devem tomar cuidados extras com a limpeza dos compartimentos de carga e guardar registros de todos os carregamentos.

- Custos do desenho/renegociação dos contratos

Os contratos são estabelecidos entre produtores e elevators ou comerciantes locais integrantes da rede da Optimum e seguem o padrão sugerido pela Du Pont.

c) Custos de monitoramento/controle

No recebimento do produto, é feito um teste para se determinar a porcentagem de óleo do grão, utilizando-se como método o teste NIRT (Near Infra-Red Technology). Assim, dada a facilidade da verificação quanto à sua qualidade, não há necessidade de monitoramento mais rígido do processo de produção. $A$ partir daí, a movimentação deste milho com alto teor de óleo, entre os armazéns credenciados e o consumidor final doméstico e no exterior, é controlado pela Optimum. 
5.4.3 Aspectos centrais da análise:

Os aspectos mais relevantes deste caso da Du Pont/Pioneer, sob a ótica da presente análise são os seguintes:

- Grande dispersão geográfica da produção e recebimento: a estratégia da empresa está centrada na larga utilização de tecnologia de informação, como redutora desse custo, desenvolvendo uma rede de contatos na Internet.

- Elevada incerteza da transação sugere o estabelecimento de contrato formal: de fato, dadas as distâncias envolvidas, vendedores de insumos, produtores e armazéns podem apresentar baixo ou nenhum relacionamento comercial a priori. O cadastramento e os contratos são feitos na própria rede.

- Prêmios pagos em função do teor de óleo: o monitoramento é feito, basicamente, na entrega do produto, evitando a necessidade de monitoramento rígido do processo de produção. Deve-se ressaltar que, além do material genético, também o manejo da cultura influenciará o resultado do prêmio, aumentando a responsabilidade do produtor com o processo. 


\title{
5.5 Genetic ID ${ }^{41}$
}

\begin{abstract}
"A Genetic ID tem como missão prover os setores agroindustriais e alimentícios da tecnologia, serviços e informação requeridas para que operem de forma segura e lucrativa no novo ambiente globalizado, crescentemente tecnificado".
\end{abstract}

Site oficial da Genetic ID

\subsubsection{Descrição do caso}

A empresa Genetic ID iniciou seus trabalhos no ano de 1996, no Estado de lowa, EUA, como resposta à crescente reação dos consumidores aos produtos transgênicos. É considerada a primeira empresa especializada na certificação de produtos não geneticamente modificados, representando o laboratório que mais realizou testes de detecção e quantificação de OGM's no mundo.

As primeiras plantas que tiveram genes incorporados ao seu material genético original, por meio de engenharia genética, foram obtidas no início dos anos 80 . Segundo Azevedo (1999), em 1987, existiam apenas cinco tipos diferentes de plantas transgênicas e, em 1995, este número elevou-se para algumas centenas, com mais de 700 ensaios em todo o mundo. Atualmente, nos EUA, quase cinqüenta espécies de plantas já contam com cultivares geneticamente modificados.

Atualmente, as características comerciais introduzidas são, principalmente, aquelas que conferem à planta transgênica resistência a pragas e insetos da agricultura, herbicidas e doenças causadas principalmente por vírus. Estas

\footnotetext{
${ }^{41}$ Esta análise baseia-se no estudo de caso apresentado no X Seminário Internacional PENSA de Agribusiness, desenvolvido por Azevedo et al. (2000), complementado com revisão bibliográfica sobre o
} 
características beneficiam diretamente o produtor rural, por meio de redução de custos de produção. Entretanto, outras características foram ou estão sendo introduzidas em plantas cultivadas que trarão benefícios diretos ao consumidor, com a melhoria da funcionalidade do alimento, ao dotar as commodities de atributos específicos de interesse dos consumidores ou das indústrias alimentar (humana e animal) e farmacêutica. Como exemplo, as plantas com maior teor protéico e/ou energético ou que contenham vacinas contra doenças.

Atualmente, as culturas com produtos transgênicos mais cultivadas são a soja e o milho, respondendo por quase $80 \%$ da soma de todas as áreas com GM's no mundo. Os Estados Unidos são o país que mais fortemente aderiram aos OGM's, tendo sido responsáveis pela produção quase $70 \%$ de toda a área de produtos transgênicos produzidos em $1999^{42}$. A evolução da participação da soja e do milho transgênicos em relação à área plantada desses produtos nos EUA pode ser observado no Gráfico 3.

A importância de mecanismos de IP para produtos não-GM's surge na mesma medida em que se inicia um processo de forte resistência a esses produtos, principalmente por parte de consumidores europeus e japoneses ${ }^{43}$. A Genetic ID, identificando esse nicho de mercado, consolida-se, então, como uma das pioneiras na certificação de produtos não OGM's, atuando em todos os continentes e baseando sua estratégia na reputação de sua marca internacionalmente. Dada a relevância da soja neste processo, pretende-se focar a discussão neste produto.

\footnotetext{
tema e pesquisa na Internet.

${ }^{42}$ estatísticas extraídas do estudo "DG AGRI, CEE, 2000, in Economic Impacts of Genetically Modified Crops on the Agri-Food Sector - A Synthesis".

${ }^{43}$ Pesquisa junto a consumidores franceses mostrou que $37 \%$ dos entrevistados se recusavam a consumir OGMs (SNIA, 1999), sentimento compartilhado por significativa parcela dos consumidores europeus. Ressalte-se que não se pretende, neste trabalho, avaliar o mérito dessa resistência aos produtos transgênicos. Essa informação será adotada como uma variável exógena ao problema, isto é, determinada por forças externas ao modelo; assim, o que se pretende analisar é: dada a resistência do consumidor a esse produto, quais seriam as estratégias das empresas para oferecer produtos livres de OGM's ao menor custo.
} 


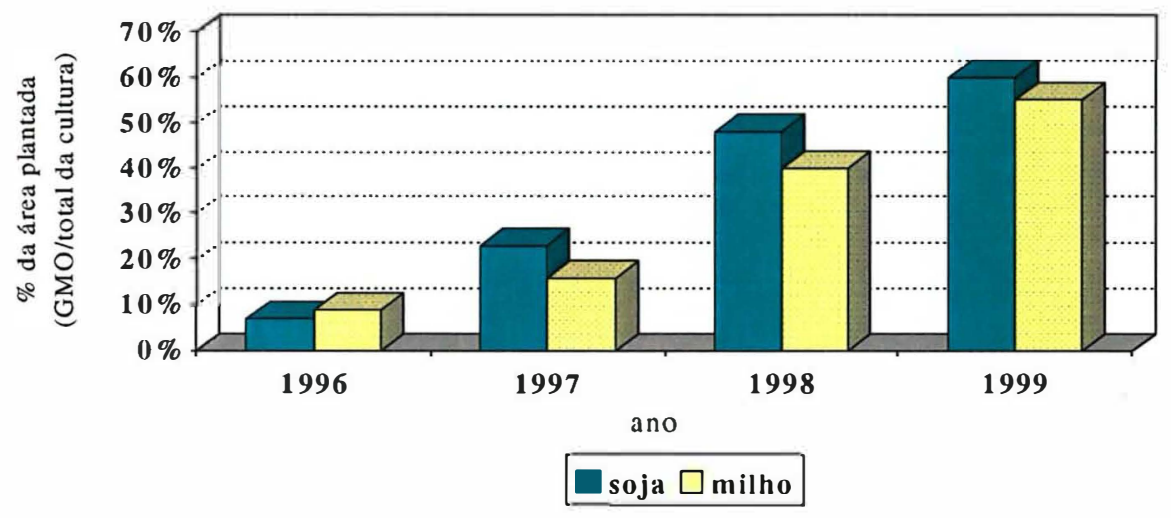

Fonte: Hahn et al. (2000)

Gráfico 3. Evolução da participação da área plantada com produtos geneticamente modificados nos Estados Unidos em relação à área total do produto, em \%.

5.5.2 Formas de coordenação e de incentivos associadas aos custos de transação

a) Custos de informação:

- Busca/Seleção de produtores

A estratégia adotada pela empresa para sua entrada no Brasil tem sido preferencialmente por meio de parcerias/alianças com cooperativas ${ }^{44}$, com forte inserção junto ao meio produtivo, que contam com cooperados de médio e pequeno portes. Esta estratégia resulta em duas importantes vantagens: a

\footnotetext{
${ }^{44}$ Segundo Azevedo (2000), a Genetic ID já mantém parcerias com a Imcopa, Cotrimaio e o terminal portuário da Cotriguaçú.
} 
primeira refere-se ao fato da possibilidade de agregação de valor do produto e melhor remuneração dos cooperados; a segunda refere-se ao seu baixo custo de implantação em relação à certificação de outros sistemas de comercialização. De fato, essas cooperativas podem monitorar o processo de produção, armazenagem e distribuição mediante um custo adicional pouco significativo, visto que elas já mantinham um relacionamento estreito com os produtores, desde o fornecimento de sementes certificadas, assistência técnica até a sua aquisição. Com isso, a empresa consegue certificar um número expressivo de empresas produtoras, a um custo mais acessivel. O processo se inicia com o compromisso da cooperativa de monitorar as ações de seus cooperados e fornecedores de insumos, previstas em um protocolo de rotinas desenvolvido pela Genetic ID. A partir daí, cooperativas, cooperados e certificadora passam a compartilhar as responsabilidades quanto à rigida obediência ao protocolo assinado.

Além disso, em seu site (http://www.genetic-id.com), a Genetic ID também oferece a possibilidade de apresentação de novos e antigos produtores certificados a compradores de produtos não-GM, a partir de um cadastro consolidado em seu banco de dados.

\section{- Formação de preços}

Ainda não há claramente, no mercado, o estabelecimento de prêmios aos grãos em relação à variável de transgenia. Alguns operadores sugerem que esses ágios variam entre 5 e $8 \%$ para o produto livre de OGM's (no caso da soja), sem que se verifique, no entanto, um valor consensual para esse montante, dado que as negociações ocorrem, via de regra, de forma individual entre empresas fornecedoras (como tradings multinacionais) e consumidoras (como grandes atacadistas e redes de supermercados européias). De qualquer forma, o que se observa é que esses prêmios, quando ocorrem, normalmente adotam, como referência, os preços das commodities internacionais. A Genetic ID tem 
proposto a cobrança de até $1,2 \%$ do valor total do produto analisado para a emissão do Cert-it, ou seja, para a certificação do processo.

b) Custos de negociação:

- Custos de reconversão e operacionalização do sistema de PI

Os custos relacionados à reconversão e operacionalização do sistema de $\mathrm{PI}$, com ênfase neste último, vinculam-se, principalmente, àqueles de segregação do produto mencionados no item 3.2.1, e estão relacionados às fases do plantio, armazenagem, transporte, processamento e distribuição. O monitoramento de todas essas fases sugere a contratação da certificação do processo. Em algumas situações, pode ocorrer também, de forma conjunta ou isolada, a certificação do produto por meio de testes laboratoriais e, nesse caso, os custos se relacionam aos preços desses testes. A Genetic ID fornece esses dois tipos de serviços, quais sejam:

- testes sobre a presença de OGM's para identificação das variedades e intensidade desta presença, que se constitui na certificação do produto;

- certificação de empresas, o Cert ID, em que atesta que a empresa certificada trabalha com produtos não-GM's. Essa certificação compreende um esquema totalmente integrado de auditorias de rastreabilidade, inspeções e teste de identificação de OGM's. Seus clientes potenciais são agricultores, indústrias de alimentos, grandes varejistas e empresas responsáveis pela logística de grãos, como armazéns e terminais portuários. Essa medida representa a certificação do processo.

As condições mais adequadas para cada uma dessas situações serão analisadas nos próximos itens. 


\section{- Custos do desenho/renegociação do contrato}

Um dos importantes desafios relacionados à contratação de empresas como a Genetic ID, refere-se ao equacionamento dos custos associados ao processo comparativamente aos prêmios oferecidos pelos produtos não transgênicos, ainda não claramente sinalizados.

Dada a atual situação, em que, de um lado, há resistência ao consumo de produtos GM's e, de outro, se verificam i) custos na produção de transgênicos inferiores aos dos produtos convencionais ${ }^{45}$, ii) custos adicionais para se segregar e testar o produto e iii) aumento na proporção mundial de produtos transgênicos (dificultando a sua segregação), a racionalidade econômica sugere a fixação de um ágio que, ao menos, cubra todos esses custos adicionais do não-transgênico. O montante do prêmio não é uma escolha das empresas, mas será o resultado da conjunção de duas variáveis: o custo do processo de $\mathrm{PI}$ e o valor específico do produto para o consumidor. Assim, um número suficiente de consumidores deveriam estar dispostos a pagar um adicional pela garantia de obter um produto não transgênico certificado, de forma a viabilizar este instrumento de certificação. Quanto mais alto este custo, no entanto, menor o grupo de consumidores disponível. A incerteza quanto o seu custo final e, mais ainda quanto ao prêmio pago pelo produto, tem gerado elevado grau de instabilidade quanto aos termos do contratos de certificação, para ambas as partes envolvidas.

c) Custos de monitoramento/controle

Considerando que o atributo do produto transgênico não pode ser facilmente identificado pela simples observação, o mercado passa a exigir processos de

\footnotetext{
${ }^{45}$ Segundo Rankin, citado por Azevedo (2000), o custo de produção da soja transgênica RR (resistente ao herbicida à base de Glifosato) chega a ser até 19\% inferior em relação à soja tradicional, no caso de plantio direto, e cerca de $13,5 \%$, no plantio convencional.
} 
certificação aos produtos não transgênicos. A primeira variável de análise desse custo de certificação recai sobre a ótica da incerteza da transação, ou seja, o risco de se obter um produto transgênico em relação a um não-transgênico. $O$ Brasil é, dentre os grandes paises produtores de grãos, o único que até agora tem optado pela adoção do princípio da precaução para os OGM's, impedindo tanto a produção quanto a comercialização desses produtos. Com isso, a produção se restringe a uma pequena parcela de produtores, que se dá pelo plantio de sementes ilegalmente trazidas de outros países, principalmente da Argentina, pela maior facilidade de acesso aos estados da região sul.

Essa situação não implica, no entanto, acesso livre aos mercados que demandam produtos livres de GM's. Estudos divulgados na Europa, disponibilizados em páginas do "site portal" oficial da UE (http://europe.eu.int), por exemplo, apontam estimativas de uma produção de soja transgênica da ordem $10 \%$, em relação à produção total, no Brasil ${ }^{46}$. Além disso, ainda não se tem registro de quaisquer prêmios apropriados pelos produtores de soja brasileiro, em função de sua não transgenia.

De qualquer maneira, qualquer apropriação de ágios, que, eventualmente, esteja sendo obtida por tradings internacionais na venda do produto, pode ser gerada a um custo inferior àquele necessário para se segregar o grão em países ou regiões onde há uma probabilidade muito elevada de que o produto seja transgênico. Assim, nas regiões centrais do País, com uma proteção maior à entrada ilegal de soja transgênica - em função das distâncias e das condições edafo-climáticas menos adaptadas às variedades argentinas (de onde vem a maior parte do produto contrabandeado) -, os riscos de comprar produtos transgênicos são muito menores. Nessas situações, testes laboratoriais, como o

\footnotetext{
${ }^{46}$ Esta estimativa de $10 \%$ é contestada por muitos, já que carece de qualquer fundamentação científica para sua apuração; no entanto, apesar de questionável, transmite uma percepção de risco aos consumidores europeus. Àqueles resistentes ao consumo de OGM`s, esta informação já é suficiente para que requeiram um certificado de produtos não transgênicos, independentemente da proibição legal da produção de OGM's no Brasil.
} 
PCR, implicam o menor custo para oferecer garantia em relação ao produto não transgênico.

Nos Estados Unidos, onde quase $60 \%$ da área plantada com soja já era transgênica em 1999, sem uma concentração regional definida, a possibilidade de se adquirir produtos à base de soja transgênica é muito elevada. Além disso, a própria logística do produto torna a PI mais onerosa, visto que a distribuição dos grãos nos EUA é feita basicamente por hidrovia e ferrovia, cujas estruturas de transporte dificultam a segregação ${ }^{47}$. A certificação, aí, recai sobre o monitoramento do processo, implicando custos bem mais elevados. A probabilidade de contaminação é uma variável chave na decisão do processo de certificação necessário.

Avaliou-se, neste exemplo, a estratégia adotada sob a ótica da proporção de soja diferenciada em relação ao total produzido. Um outro aspecto, no que tange às incertezas para essa transação, refere-se a um atributo genético. Quanto maior a possibilidade de transposições genéticas que podem ser feitas a um produto, maior dificuldade a certificadora encontrará para identificar o espectro de análises necessárias para confirmar a não-transgenia. Além disso, novos testes deverão ser desenvolvidos para cada configuração genética alternativa. Dessa forma, tanto o desenvolvimento do teste quanto a sua aplicação, implicará elevação imprevisível e significativa nos custos envolvidos. Kerr (1999) sugere que a simples possibilidade de ter que realizar 50 ou 100 análises químicas para certificar um carregamento de batata importada, por exemplo, representa uma significativa barreira à comercialização. Marcadores genéticos podem diminuir a necessidade desses testes. Não está claro, porém, se esses marcadores poderiam ser introduzidos deliberadamente de forma a confundir ou evitar determinados testes. Além disso, processos de cozimento e outras técnicas de processamento geralmente destroem o gene introduzido,

\footnotetext{
${ }^{47}$ A matriz de transporte de grãos nos EUA, diferentemente do Brasil, privilegia os modais hidroviário e ferroviário. Segundo o Anuário Estatístico... 1998, 61\% da soja comercializada naquele país é transportada por hidrovia e $16 \%$ é feito por ferrovia.
} 
dificultando a sua identificação nas fases a montante das esmagadoras de soja ${ }^{48}$,

Finalmente, ainda devem-se analisar os custos da certificação do processo vis à vis do produto, em relação à freqüência da transação. Considerando que a certificação do processo chega a custar até $1,2 \%$ do valor do produto e tem vigência de um ano, ela deixa de ser interessante se a produção também for anual. O custo da certificação do produto, ou teste PCR, representa menos de $0,20 \%$ do valor do produto, no caso da soja. Assim, i) se não houver exigência da certificação do processo, por parte do comprador; ii) se a probabilidade de contaminação for baixa (no caso de certas regiões do Brasil) e iii) se a freqüência da entrega também for baixa (no caso da soja, somente uma vez por ano), possivelmente a emissão da certificação do produto se tornaria mais interessante.

Assim, verifica-se que as empresas certificadoras, no caso de segregação de produtos com atributos indesejados, pode adotar estratégias distintas, que podem ser sistematizadas segundo as seguintes caraterísticas da transação:

- incerteza, relacionada i) à probabilidade de "contaminação" com produto transgênico e ii) à dificuldade de se analisar todos os atributos genéticos, característica diretamente condicionada pela possibilidade de combinações genéticas,

- freqüência.

\footnotetext{
${ }^{48}$ Segundo Kerr (1999), cerca de $60 \%$ dos alimentos industrializados contém soja. Esse percentual inclui a soja que entra diretamente na composição de um significativo número de produtos alimentícios como massas, cereais matinais, pão, óleo de soja, sorvetes, margarinas, molho à base de soja etc. Há também o consumo indireto, por meio da soja que entra na composição da ração destinada à alimentação animal, como aves, suínos e bovinos.
} 


\subsubsection{Aspectos centrais da análise:}

Os aspectos mais relevantes desse caso da Genetic ID, sob a ótica da presente análise são os seguintes:

- Intangibilidade do produto transgênico, exigindo a necessidade de algum tipo de certificação

- Busca e seleção de produtores: são feitas, prioritariamente, por meio de alianças com cooperativas. Essa estratégia permite o compartilhamento de responsabilidades, desonerando o sistema (as cooperativas selecionadas já mantêm estreito relacionamento com cooperados). Além disso, a empresa disponibiliza um serviço na Internet que coloca em contato potenciais compradores e vendedores;

- Possibilidade de certificação do processo ou do produto: as duas alternativas são avaliadas, segundo características de incerteza e freqüência da transação, buscando estratégias que minimizem custos e falhas ao processo;

- Incerteza quanto aos rumos do mercado que dificultam a definição dos contratos e as estratégias de longo prazo das empresas;

- Política da precaução adotada pelas instituicões brasileiras: esse aspecto tem favorecido estratégias empresariais diferenciadas, segundo a categoria de fornecedores e segundo a região do País originadora do grão. 
6 RESULTADOS

E DISCUSSÃO 


\section{RESULTADOS E DISCUSSÃO}

Neste capitulo, pretende-se avaliar e discutir os resultados da pesquisa. Serão testadas as três hipóteses propostas na introdução do trabalho, à luz dos estudos empíricos analisados no capítulo 5, confrontando-se com o arcabouço teórico apresentado nos capítulos 2 e 3.

a) hipótese 1: a primeira hipótese sugeria que as formas de minimizar os custos envolvidos em processos de $\mathrm{Pl}$ dependem das caraterísticas das transações e dos atributos dos produtos e demandam o estabelecimento de contratos, formais ou informais.

Conforme pode-se constatar nos casos analisados, corroborando a teoria da ECT, o aumento da especificidade das transações, de fato, sugere o estabelecimento de algum nivel de comprometimento entre produtores e compradores. Dado que a freqüência de transação entre produtor e agroindústria é relativamente baixa no caso dos grãos - seja commodity, seja produto diferenciado -, a análise será focada nos atributos de incerteza (riscos de distúrbios relacionados aos custos mais elevados) e de especificidade de ativo (que será analisada sob a ótica de grau de dependência da indústria ao produto diferenciado).

Pode-se verificar que, em todos os estudos de casos, há alguma forma de coordenação, com algum grau de compromisso, alterando a forma de governança predominante no SAG tradicional, cuja principal sinalização é o 
preço, corroborando esta primeira hipótese. No entanto, dependendo das características da transação, a pesquisa permitiu verificar, a existência de relações mais tênues ou com maior grau de comprometimento entre as partes. De fato, Williamson (1985) descreve os contratos como relações que também podem envolver niveis distintos de comprometimento. A forma hibrida é aquela que tenta manter as características de incentivos proporcionadas pelo mercado, privilegiando adaptações que minimizem os custos de transação. A falta de algum grau de comprometimento implicaria, fatalmente, falhas em outras variáveis do mercado, tais como excesso ou falta de oferta de um produto diferenciado em relação à sua demanda, falta de sinalização clara quanto ao nivel de qualidade requerida ou riscos de contaminação ao longo do processo. Os principais mecanismos de coordenação adotados em cada caso, associados às características da transação de especificidade e incerteza (risco) podem ser observadas no Quadro 10.

No primeiro caso analisado, soja orgânica, verifica-se um elevado grau de especificidade, associado a um alto custo adicional de produção e de PI. Do lado do produtor, há elevados riscos advindos, principalmente, de custos adicionais, tanto em função do manejo mais oneroso, quanto à diminuição de produtividade. Verifica-se incerteza, também, no que se refere à qualidade do produto final e, consequentemente, ao valor do prêmio. Do lado da empresa compradora, podem-se identificar elevados investimentos em ativos dedicados para segregar o produto, desde o recebimento até o embarque no porto. A especificidade é, também, muito elevada, já que não há nenhum substituto para a soja orgânica, principalmente para a produção de alimentos. Como conseqüência, observa-se, como forma de governança, o estabelecimento de contratos formais entre as partes para compra do produto e fornecimento de insumos. 


\begin{tabular}{|l|c|c|l|}
\hline \multicolumn{1}{|c|}{ Produto } & Especificidade & $\begin{array}{c}\text { Incerteza } \\
\text { (risco) }\end{array}$ & Relação contratual \\
\hline Soja orgânica & +++ & ++ & $\begin{array}{l}\text { Contrato formal de } \\
\text { compra e de } \\
\text { fornecimento de } \\
\text { insumos }\end{array}$ \\
\hline Cafés especiais & + & + & $\begin{array}{l}\text { Promessa } \\
\text { compra de }\end{array}$ \\
\hline Milho ceroso (waxy) & ++ & ++ & $\begin{array}{l}\text { Contrato formal de } \\
\text { compra }\end{array}$ \\
\hline Milho com alto teor de óleo & ++ & ++ & $\begin{array}{l}\text { Contrato formal de } \\
\text { compra }\end{array}$ \\
\hline (high oil corn - HOC) & + & + & $\begin{array}{l}\text { Contrato } \\
\text { compartilhamento de } \\
\text { de responsabilidade }\end{array}$ \\
\hline Soja não-transgênica & & &
\end{tabular}

Legenda: $(+)=$ baixo; $\quad(++)=$ médio, $\mathrm{e} \quad(+++)=$ alto

Fonte: resultado da pesquisa

Quadro 10. Relação entre os produtos analisados, características das transações e tipos de relação entre as partes.

No segundo caso, produção e distribuição de cafés especiais, percebe-se um relacionamento mais tênue, com uma forma de governança mais próxima de "promessa de compra". Nela, o comprador sinaliza, via concursos, que se o produto estiver dentro da qualidade requerida, haverá a transação e pagamento de ágio. Nessa situação, tanto os níveis de incerteza quanto os de especificidade do ativo são menores. Não há uma preocupação significativa do produtor em investimentos e tratos culturais específicos. Visando à produção com qualidade de tipo superior, ele já realiza o manejo necessário para obter um produto diferenciado. A partir daí, a região propícia e as condições edafo- 
climáticas serão as variáveis decisivas para o enquadramento do produto dentro dos padrões extremamente rígidos da empresa em questão. Por outro lado, apesar da alta especificidade do produto, ela também poderá ser relativizada pelo comprador no momento da transação, na medida em que o blend permite várias combinações, misturando cafés de diferentes tipos e origens.

No terceiro caso analisado, o milho ceroso (ou waxy), observa-se médio nivel de incerteza ao produtor, visto que, praticamente, não há custos adicionais, em relação à produção de milho commodity, já que o preço da semente de milho waxy e a sua produtividade são compativeis com os demais produtos de alta tecnologia. Além disso, a região apresenta pequena propensão à produção de culturas alternativas, como a soja. Em último caso, na ausência de comprador do milho ceroso, o agricultor poderá vender o produto como milho commodity, perdendo, no entanto, o ágio de $10 \%$. Para a empresa compradora, no entanto, há custos relativos à contratação e distribuição de sementes, distribuição e segregação do produto e custos industriais. O produto industrial final é altamente específico e comercializado para nichos específicos de mercado, basicamente no exterior. Além disso, no Brasil, somente uma empresa fornece e comercializa o produto, o que aumenta a dependência da empresa. $O$ contrato formal é o que minimiza os custos de transacão.

O quarto caso estudado foi o do milho com alto teor de óleo (HOC). Há custos adicionais de produção e distribuição e, se não for comercializado com essa especificação, não remunera os custos adicionais ao produtor, que passa, portanto, a incorrer em riscos não desprezíveis. Além disso, há incertezas quanto ao nivel de óleo no produto final, o que irá condicionar o valor do pagamento do ágio. As empresas compradoras, principalmente os avicultores, têm obtido significativo retorno financeiro com este produto, o que confere aumento da especificidade do produto e necessidade do estabelecimento de contratos formais. 
Finalmente, foi abordada a soja não transgênica, que passa a ganhar importância na medida em que aumenta a resistência aos OGM's por parte de alguns consumidores e, concomitantemente, a sua produção em escala comercial no mundo. Entretanto, a situação brasileira apresenta peculiaridades em relação à dos demais países. Se de um lado, o produtor deixa de ter redução nos seus custos ao não produzir transgênicos, isso não representa uma vantagem direta, visto que a sua proibição legal impõe riscos também para o agricultor que queira produzi-la no País. Do lado do comprador, a pequena produção de transgênico clandestino, além de sua concentração em determinadas regiões, faz com que a sua dependência do produto diminua em relação a produtores específicos. Parcerias de empresas certificadoras com cooperativas têm possibilitado a garantia de PI de não transgênico a um baixo custo de transação. No caso analisado, há um contrato de compartilhamento de responsabilidades. O Gráfico 4 relaciona a forma de governança adotada pelas organizações, como resposta aos niveis de incerteza e da especificidade dos ativos observados. 


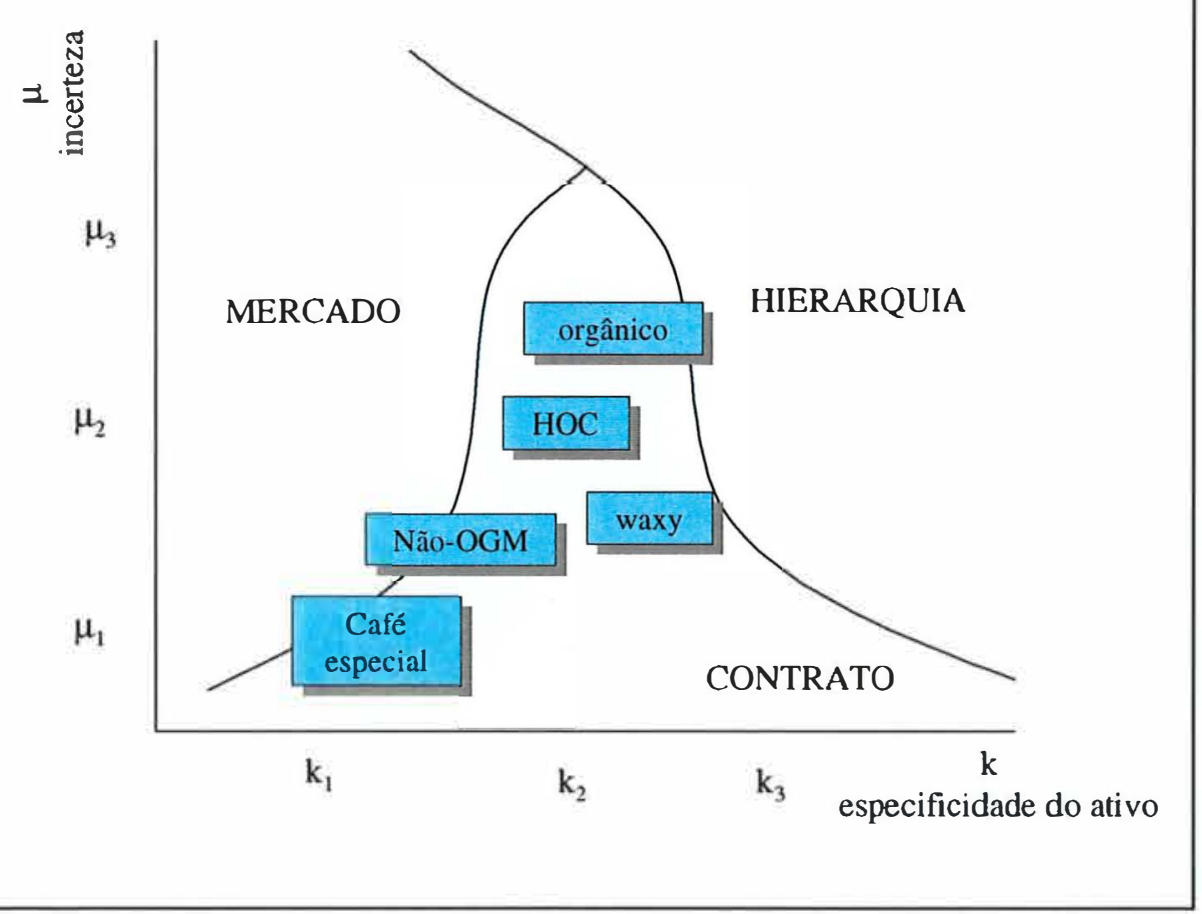

Fonte: elaborado pelo autor, a partir dos resultados da pesquisa e de Williamson (1991)

Gráfico 4. Associação entre as formas de governança e os níveis de especificidade e incerteza. 
b) hipótese 2: a segunda hipótese propunha que as estratégias de PI dependiam de mecanismos de (i) incentivo, (ii) monitoramento e (iii) tecnologias de informação que, por sua vez, seriam determinados pelos atributos específicos dessas transações e dos produtos.

i) quanto aos incentivos, verificou-se que estão, necessariamente, associados aos custos e à incerteza da transação. Quanto maior o risco na comercialização elou o custo para se produzir um bem alternativo, maior o desejo do produtor em receber um prêmio maior. Conforme já apresentado, preços com ágios são incentivos poderosos, mas não são os únicos: assistência técnica, adiantamento de insumos ou compartilhamento de riscos são variáveis importantes nas relações entre produtores e compradores. A partir dos custos discutidos no item anterior, foi elaborado o Quadro 11. Nele, foram consolidados os incentivos associados aos custos observados na pesquisa. De fato, verifica-se uma relação direta entre essas duas variáveis. 


\begin{tabular}{|c|c|c|}
\hline Produto & $\begin{array}{l}\text { Custos } \\
\text { adicionais }\end{array}$ & Incentivos \\
\hline Soja orgânica & +++ & $\begin{array}{l}\text { - Ágio de até } 40 \% \\
\text { - Incentivos progressivos } \\
\text { - Assistência técnica }\end{array}$ \\
\hline Cafés especiais & + & 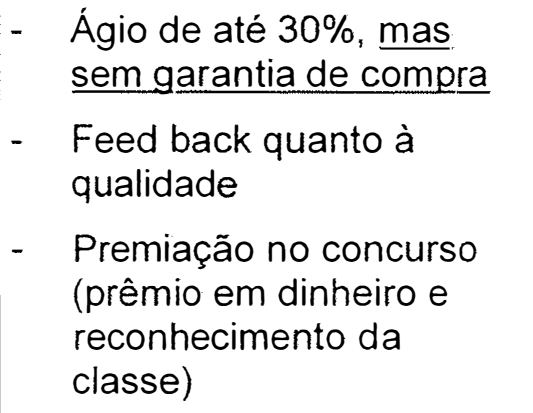 \\
\hline Milho ceroso (waxy) & ++ & $\begin{array}{l}\text { - } \quad \text { Ágio de } 10 \% \\
\text { - } \quad \text { Financiamento de } \\
\text { sementes e fertilizantes }\end{array}$ \\
\hline $\begin{array}{l}\text { Milho com alto teor de óleo } \\
\text { (high oil corn - HOC) }\end{array}$ & ++ & $\begin{array}{l}\text { Ágio proporcional ao teor } \\
\text { de óleo } \\
\text { - Facilidade para localizar } \\
\text { fornecedores de sementes } \\
\text { e locais de entrega }\end{array}$ \\
\hline Soja não-transgênica & + & 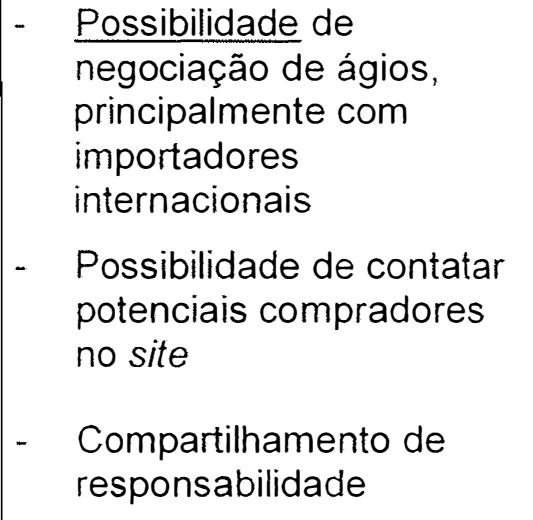 \\
\hline
\end{tabular}

Legenda: $(+)=$ baixo; $(++)=$ médio, e $(+++)=$ alto

Fonte: resultado da pesquisa

Quadro 11. Relação entre os custos adicionais e incentivos dos produtos analisados. 
ii) no que refere ao monitoramento do sistema de $\mathrm{PI}$, pode-se dividir a discussão em duas partes: a primeira relaciona-se ao nivel de assimetria informacional associada aos atributos do produto. Assim, produtos cujo atributo é facilmente identificável requerem um nível de monitoramento distinto daquele em que não se percebem facilmente as qualidades desejáveis.

Segundo os resultados empíricos observados, pode-se presumir quatro funções para os custos de transações, segundo os diferentes niveis de diferenciação de produto:

$M k t=M(a ; \theta)$, para forma de mercado, com padronizaçao definida,

Cont $=\mathrm{Cn}(\mathrm{a} ; \theta)$, para forma contratual,

Cert_pdt $=\operatorname{Ct}(a ; \theta)$, para forma contratual com processos de certificação $\underline{\text { do }}$ produto,

Cert_prc $=\mathrm{Ct}(\mathrm{a} ; \theta)$, para forma contratual com processos de certificação do processo, e

Ras $=R(a ; \theta)$, para processos de rastreabilidade,

onde a representa o nível de assimetria informacional entre produtor e consumidor, representada pelo grau de diferenciação do produto e $\theta$, o vetor de parâmetros de deslocamento .

Assume-se, também, que:

Mkt $(0, \theta)<$ Cont $(0, \theta)<$ Cert_pdt $(0, \theta)<$ Cert_prc $(0, \theta)<\operatorname{Ras}(0, \theta)$, e que

Mkt' >Cont' > Cert_pdt' > Cert_prc' > Ras' 
Assim, com baixo nível de diferenciação do produto, a assimetria informacional é praticamente nula, visto que o que se deseja é o produto milho ou soja, independente do processo de produção, origem ou qualidade. Nesse caso, o modo de mercado é a estrutura associada ao menor custo de transação; ou seja, a sinalização do preço é suficiente para a eficiência do mercado, desde que o sistema de padronização atenda às especificações mínimas requeridas, como níveis de impureza ou umidade. Com o aumento da diferenciação do produto, ocorre, também, o aumento da inabilidade do mercado para lidar com adaptações, sugerindo o estabelecimento de contratos entre as partes. $\mathrm{Na}$ situação em que o produto é diferenciado, porém facilmente identificável - com atributos visíveis ou facilmente perceptíveis -, as formas contratuais entre as partes são a maneira mais eficiente de monitoramento.

Na medida em que a assimetria informacional aumenta, o mercado já demanda processos de certificação que permitam diminuir as incertezas do comprador, quer quanto ao produto, quer quanto ao processo. Se facilmente identificável por testes laboratoriais, a certificação ao produto é a mais desejável; caso contrário, a certificação ao processo é a que minimiza os custos de monitoramento. Empresas certificadoras ou associações de classe podem exercer estas duas funções. Finalmente, em algumas situações, em que a não observância dos atributos pode gerar riscos à saúde ou em que haja necessidade de identificação da origem de um determinado lote do produto, surge a necessidade de processos de rastreabilidade. O Gráfico 5 ilustra essa situação. 


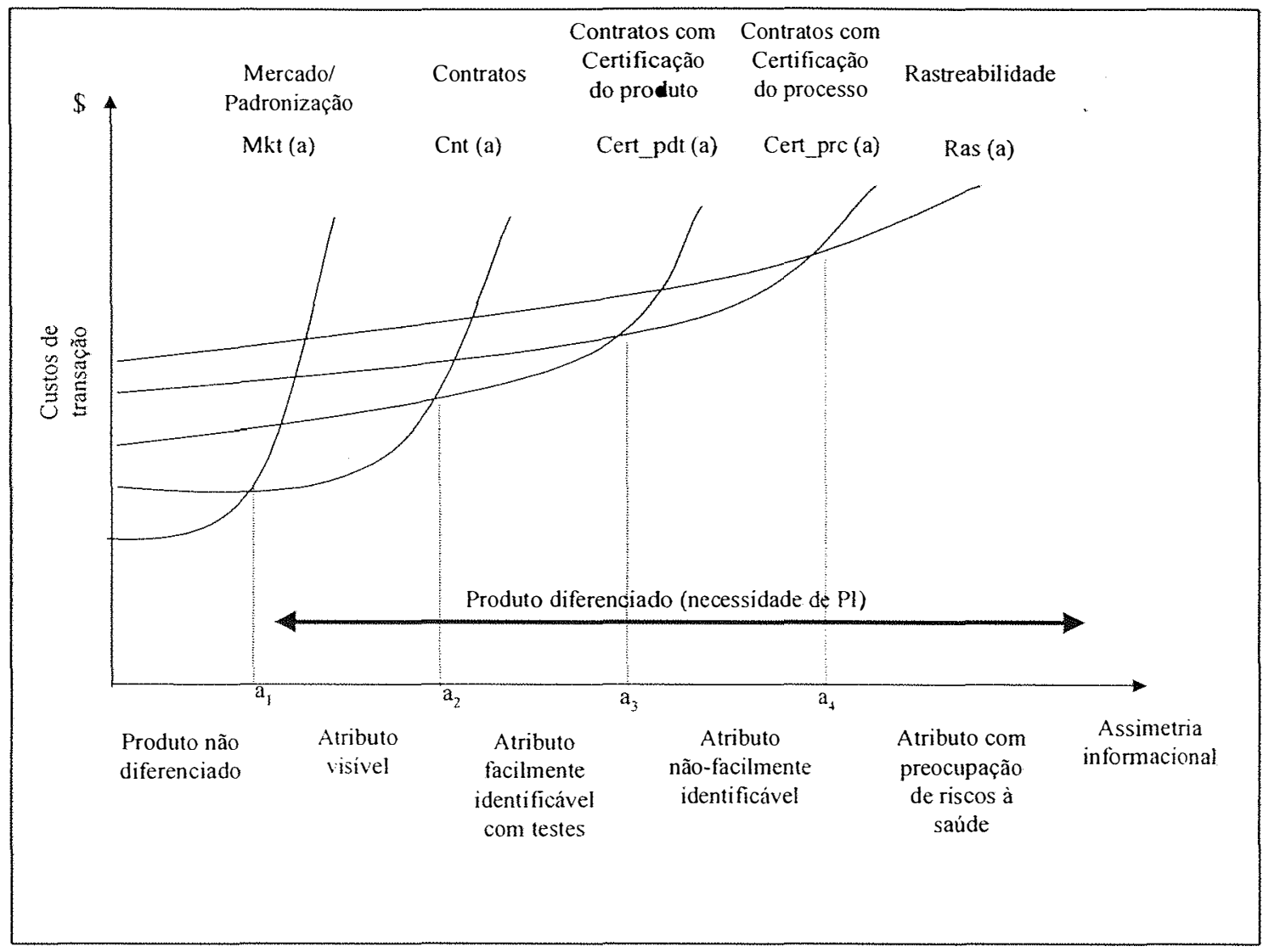

Fonte: elaborado pelo autor, a partir dos resultados da pesquisa

Gráfico 5. Curvas das funções reduzidas para os custos de transações segundo - nível de diferenciação do produto, dada uma determinada estratégia de ação da empresa e/ou SAG .

O Quadro 12 consolida os principais resultados dos estudos empíricos que corroboram a avaliação teórica. 


\begin{tabular}{|c|c|c|c|}
\hline Produto & $\begin{array}{l}\text { Característica do } \\
\text { atributo }\end{array}$ & $\begin{array}{l}\text { Assimetria } \\
\text { informacional }\end{array}$ & $\begin{array}{c}\text { Forma de } \\
\text { monitoramento }\end{array}$ \\
\hline Soja orgânica & $\begin{array}{l}\text { não facilmente } \\
\text { identificável } \\
\text { forte restrição do } \\
\text { consumidor ao produto } \\
\text { contaminado }\end{array}$ & +++ & $\begin{array}{l}\text { Certificação do } \\
\text { processo } \\
\text { Rastreabilidade }\end{array}$ \\
\hline Cafés especiais & $\begin{array}{l}\text { identificável por testes } \\
\text { consumidor identifica } \\
\text { pelo sabor e aroma } \\
\text { diferenciados }\end{array}$ & ++ & $\begin{array}{l}\text { Testes laboratoriais } \\
\text { ex-ante à transação }\end{array}$ \\
\hline Milho ceroso (waxy) & $\begin{array}{l}\text { visível ou facilmente } \\
\text { identificável por testes } \\
\text { instantâneos } \\
\text { consumidor do produto } \\
\text { industrial confia na } \\
\text { reputação da primeira } \\
\text { processadora }\end{array}$ & + & $\begin{array}{l}\text { Visitas esporádicas } \\
\text { à lavoura } \\
\text { Testes visuais ou } \\
\text { Testes instantâneos } \\
\text { e simples, se } \\
\text { necessários }\end{array}$ \\
\hline $\begin{array}{l}\text { Milho com alto teor de } \\
\text { óleo } \\
\text { (high oil corn - HOC) }\end{array}$ & Identificável por testes & ++ & $\begin{array}{l}\text { Possibilidade de } \\
\text { visitas aleatórias } \\
\text { Realização de } \\
\text { testes na entrega } \\
\text { do produto }\end{array}$ \\
\hline Soja não-transgênica & $\begin{array}{l}\text { não facilmente } \\
\text { identificado } \\
\text { processos de } \\
\text { cozimento podem } \\
\text { destrui o gene, } \\
\text { impossibilitando a } \\
\text { identificação a } \\
\text { posteriori }\end{array}$ & ++ & $\begin{array}{lr}\text { Certificação } & \text { do } \\
\text { processo } & \\
\text { Certificação } & \text { do } \\
\text { produto } & \text { (testes } \\
\text { PCR) } & \end{array}$ \\
\hline
\end{tabular}

Legenda: $(+)=$ baixo; $(++)=$ médio, e $(+++)=$ alto

Fonte: dados da pesquisa

Quadro 12. Associação entre os atributos do produto, nível de assimetria informacional e formas de monitoramento observadas. 
O segundo enfoque relacionado ao monitoramento refere-se à decisão entre a certificação do produto e do processo. Segundo a análise teórica, e corroborado pelos estudos empíricos, características de incerteza e freqüência são determinantes para a estratégia minimizadora de custos.

Em situações de incerteza alta, seja no que se refere à qualidade, seja no que tange à quantidade, a certificação sobre o processo será preferível. A incerteza quanto à qualidade refere-se à dificuldade de identificação dos atributos (ou que os testes laboratoriais sejam onerosos e/ou complexos), ou ainda que os atributos que se deseja identificar possam ser destruídos em processos industriais (testes não confiáveis). Neste caso, opta-se pela certificação sobre o processo. É o caso observado da soja orgânica.

No que se refere à incerteza sobre a quantidade, esta análise considera, basicamente, a proporção entre o produto com atributo desejável e aquele indesejável. Quando a proporção do primeiro for baixa em relação ao segundo (elevando, portanto, a incerteza), a certificação sobre o processo também será preferivel, principalmente se os testes para identificação não forem muito simples e/ou mais baratos do que a certificação sobre o processo. Em uma situação oposta, proporção do produto com atributo desejável muito maior, e com testes fáceis e confiáveis, será preferivel a certificação sobre o produto. É o caso da soja transgênica no Brasil, quando originada em regiões com pequena probabilidade da existência de sementes de OGM clandestina.

A análise sobre a freqüência também deve ser feita à luz dos custos e da confiabilidade dos testes, vis à vis os custos da certificação sobre o processo. Assim, se houver uma aita freqüência de transações (entregas de lotes), a certificação sobre o processo poderá ser a estratégia minimizadora de custos para a PI de um determinado produto, dado que haverá o aumento de custos 
para certificação do produto. A consolidação dessa análise pode ser observada no Quadro 13.

\begin{tabular}{|c|c|c|c|}
\hline \multicolumn{2}{|c|}{ Característica da transação } & \multicolumn{2}{|c|}{ Certificação } \\
\hline & & Processo & Produto \\
\hline $\begin{array}{l}\text { Incerteza } \\
\text { (Qualidade) }\end{array}$ & $\begin{array}{l}\text { Alta } \\
\text { Baixa }\end{array}$ & $x$ & $\mathrm{x}$ \\
\hline $\begin{array}{l}\text { Incerteza } \\
\text { (Quantidade) }\end{array}$ & $\begin{array}{l}\text { Alta } \\
\text { Baixa }\end{array}$ & $x$ & $\mathrm{x}$ \\
\hline Freqüência & $\begin{array}{l}\text { Alta } \\
\text { Baixa }\end{array}$ & $x$ & $\mathrm{x}$ \\
\hline
\end{tabular}

Fonte: resultados da pesquisa

Quadro 13. Associação entre as características de incerteza e freqüência e processos de certificação e do produto.

iii) a última variável refere-se ao uso de tecnologia da informação como minimizador de custo em sistemas de PI. Para as fases do SAG analisadas - a relação produtor-agroindústria -, recursos via Internet mostraram-se bastante eficientes, principalmente em situações de elevada dispersão geográfica entre os agentes. É o caso do milho com alto teor de óleo; por meio da rede mundial, a empresa pode coordenar as transações entre empresas (produtoras de sementes, produtores rurais, armazéns, avícolas e suinícolas), envolvendo grandes distâncias espaciais e, dessa forma, reduzindo significativamente os custos dessas transações. Este recurso também tem sido utilizado para compradores e vendedores potenciais de produtos transgênicos no site da 
empresa certificadora, conforme verificado no estudo.

Outra forma de TI refere-se aos testes laboratoriais. É um instrumento indutor da redução de custos nas situações de PI, interferindo, inclusive, nas estratégias das empresas. Assim, testes mais baratos e confiáveis podem substituir complexos e onerosos sistemas de certificação do processo, conforme já discutido neste item. Exemplos são os testes de PCR, para produtos transgênicos e o NIRT, que permite a medição da percentagem do teor de óleo no grão, utilizada na PI do milho HOC.

Dessa forma, não se refuta esta segunda hipótese que condicionava os custos de $\mathrm{PI}$ a estratégias relacionadas a formas de incentivo, monitoramento e tecnologias de informação. Esses mecanismos, por sua vez, são determinados pelos atributos especificos das transações e dos produtos envolvidos. 
c) hipótese 3: finalmente, a terceira hipótese sugeria que a existência de bens públicos e coletivos que atuassem, principalmente, na diminuição da assimetria informacional seria um importante redutor de custos de PI. O ambiente institucional mostrou-se relevante na redução de custos, sob diversas formas.

Ao Estado cabe o papel de garantidor do funcionamento das instituições e estimulador das ações produtivas. Para processos de PI, uma das mais importantes formas de redução de custos refere-se a um claro e completo sistema de padronização de qualidade e de segurança do alimento, para o qual o governo (bem público) e as associações de classe (bem coletivo) exercem um papel fundamental. Padrões que permitam comparabilidade e intercambialidade possibilitam reduções nos custos de informação e de busca do produto no mercado. A sua implementação colabora de maneira significativa com a diminuição da assimetria informacional. Nesse sentido, deve-se ressaltar a importância da reputação do Estado e/ou das associações, relacionada à sua capacidade de monitoramento de ações geradoras e controladoras dos padrões desejados, assim como sua capacidade coercitiva, no caso de inobservância das normas.

Problemas de padronização e classificação oficiais foram identificados na entrevista com o represente da empresa que comercializa o milho waxy, visto que o atual sistema governamental não contempla os padrões mínimos requeridos pela indústria. Esta falha de mercado gera a necessidade do estabelecimento de padrões entre as partes, independentemente dos atributos diferenciados. Há, também, um esforço no sentido de que seja adotado, no País, um padrão para produtos orgânicos aceito mundialmente, segundo o representante da empresa que comercializa soja orgânica.

Outras formas de ações coletivas contempladas no presente estudo que podem beneficiar o sistema de PI são a criação de selos de pureza de café (ABIC) e as negociações com o terminal ferroviário que permitiram a adaptação de estrutura 
de logística, facilitando a segregação do produto (ACARPA).

Duas outras importantes ações públicas que, também, permitirão a redução nos custos de PI foram identificadas no presente estudo:

- reforma na lei da armazenagem, que permitirá a redução nos custos de transação para ações de segregação do produto e monitoramento do processo;

- ações que possibilitem a maior disseminação da Internet. Com isso, viabiliza-se o incremento de processos de tecnologia de informação, como as já discutidas, que permitem realizar processos de seleção, busca de parceiras e planejamento logístico, a custos reduzidos.

Assim, da mesma forma que as demais hipóteses testadas, não se pode rejeitar esta terceira, que sugere que bens públicos e coletivos podem reduzir custos de $\mathrm{PI}$, atuando, principalmente, na redução de assimetria informacional. Outros benefícios, como o provimento de acessos a instrumentos de tecnologia de informação e reformas na legislação também foram evidenciados. 
7 CONCLUSÕES 


\section{CONCLUSÕES}

\subsection{Conclusões gerais}

O presente trabalho de tese buscou analisar e compreender as transformações que já começam a ocorrer nos sistemas agroindustriais com o aumento da especificidade dos grãos, tradicionalmente produzidos e comercializados sem qualquer especialização. O referencial teórico utilizado, a Economia de Custos de Transação, forneceu o arcabouço para a formulação das hipóteses e sistematização da análise. Os estudos de caso, envolvendo situações de PI no Brasil e exterior, foram importantes para validar o referencial teórico.

Assim, os resultados da presente investigação permitem as seguintes conclusões:

- A necessidade de segregação de novos atributos é uma realidade e representa importante desafio para todos os agentes que compõem os sistemas agroindustriais. Este trabalho enfocou basicamente a relação produtor-agroindústria, um dos elos mais impactados, com estas transformações, dada a sua tradição de operar em transações via mercado. Essa tendência implica necessidade de importantes adaptações e alteração naquela forma de governança predominante, que passa a ser realizada, prioritariamente, sob a forma de relações contratuais. 
- Esses contratos podem ter várias formas, dependendo das características da transação. A pesquisa permitiu verificar desde a existência de relações mais tênues, como as que envolvem promessa de compra ou compartilhamento de responsabilidade, até aquelas com maior grau de comprometimento entre as partes, como os contratos formais de compra, contratos de gerenciamento da produção e/ou de fornecimento de insumos. A falta de algum grau de comprometimento implicaria, fatalmente, falhas em outras variáveis do mercado, tais como excesso ou falta de oferta de um produto diferenciado em relação à sua demanda, falta de sinalização clara quanto ao nível de qualidade requerida ou riscos de contaminação ao longo do processo.

- A preservação de identidade implica aumento nos custos, que permeiam todas as fases da cadeia produtiva, em proporções variáveis conforme a característica que se deseja preservar. Estão presentes no plantio, manejo, armazenagem, transporte, processamento e distribuição e a sua administração é que irá condicionar a competitividade da cadeia. Esses custos são identificáveis e têm forte relação com as características das transações e com os atributos do produto que se deseja segregar. Os custos adicionais de produção, distribuição e processamento vão depender, basicamente, das seguintes características: tolerância à contaminação, aspectos agronômicos, especificidade temporal e quantidade de produtos derivados.

- Estratégias de incentivo e monitoramento são fundamentais para o sucesso do sistema de PI. Os incentivos vão estar diretamente relacionados aos custos e à incerteza da transação. Quanto maior o risco na comercialização elou o custo para se produzir um bem alternativo, maior o desejo do produtor de receber um prêmio maior. A pesquisa apontou que ágios aos preços são incentivos poderosos, mas não são os únicos: assistência técnica, adiantamento de insumos ou compartilhamento de riscos, via 
parcerias entre outros, são mecanismos importantes nas relações entre produtores e compradores.

- O monitoramento está fortemente relacionado ao nível de assimetria informacional que, por sua vez, associa-se aos atributos do produto. Assim, atributos facilmente identificáveis requerem um nivel de monitoramento distinto daqueles em que não se percebem, facilmente, as qualidades desejáveis. Em situações de baixo grau de diferenciação, a assimetria informacional é praticamente nula, sendo o mercado considerado como a estrutura associada ao menor custo de transação. Com o aumento da diferenciação, ocorre, também, o aumento da inabilidade do mercado para lidar com adaptações, sugerindo o estabelecimento de contratos entre as partes. Na situação em que o produto é diferenciado, porém facilmente identificável - com atributos visiveis ou facilmente perceptiveis -, as formas contratuais entre as partes são a maneira mais eficiente de monitoramento. $\mathrm{Na}$ medida em que a assimetria informacional aumenta, o mercado já demanda processos de certificação que permitam diminuir as incertezas do comprador, quer quanto ao produto, quer quanto ao processo. Se facilmente identificável por testes laboratoriais, a certificação ao produto é a mais desejável; caso contrário, a certificação ao processo é a que minimiza os custos de monitoramento. Finalmente, em algumas situações, em que a não observância dos atributos pode gerar riscos à saúde ou haja necessidade de identificação da origem de um determinado lote do produto, são necessários processos de rastreabilidade.

- A tecnologia da informação como mecanismo minimizador de custo em sistemas de PI, mostrou-se bastante eficiente em algumas situações, como as que envolvem recursos de Internet, na busca e seleção de parceiros, principalmente em situações de elevada dispersão geográfica entre os agentes. Outra forma de tecnologia refere-se aos testes laboratoriais, como um instrumento indutor da redução de custos nas situações de $\mathrm{PI}$, 
interferindo, inclusive, nas estratégias das empresas. Assim, testes mais baratos e confiáveis podem substituir complexos e onerosos sistemas de certificação do processo.

- Finalmente, cabe ressaltar o papel dos bens públicos e privados como agentes redutores de custos nos sistemas de PI. Uma dessas formas referese a um claro e completo sistema de padronização de qualidade e de segurança do alimento, para o qual o governo (bem público) e as associações de classe (bem coletivo) são fundamentais. Padrões que permitam comparabilidade e intercambialidade possibilitam reduções no custos de informação e de busca do produto no mercado e a sua implementação colabora de maneira significativa para a diminuição da assimetria informacional. Outras formas de ações coletivas, contempladas no presente estudo, que podem beneficiar o sistema de PI são a criação de selos de qualidade desenvolvidos pelas associações de classe. Reformas na legislação de armazenagem e ações que possibilitem a maior disseminação da Internet também foram identificadas como importantes bens públicos que dariam maior eficiência ao sistema.

\subsection{Comentários finais e proposta de novas pesquisas}

O presente estudo se propôs a sistematizar conhecimentos relacionados a um tema emergente, que são os sistemas de preservação de identidade de grãos. Para corroborar vários desses conceitos, foram utilizados cinco casos recentes, com grande diversidade de características de transações e atributos que se pretendiam segregar, visando a uma maior abrangência da análise. Uma primeira limitação identificada refere-se ao tamanho pequeno da amostra, o que impede, por si só, maiores generalizações. Permitiu, no entanto, avanços na 
compreensão da realidade organizacional, a validação de vários conceitos teóricos e a observação de novos elementos a serem considerados.

Uma outra limitação refere-se à pouca maturidade dessas experiências, visto que são, em sua maioria, muito recentes. Assim, assumi-las como experiências de sucesso no longo prazo pode gerar uma distorção nos resultados. No entanto, até o momento da realização desse estudo, mostravam-se como estratégias superiores (em eficiência) e, como tal, eram reconhecidas pelo mercado. Assim, uma revisita a esses casos, e demais empresas que seguiram estratégias semelhantes, ofereceria maior robustez aos resultados da pesquisa, dado o ambiente altamente mutante neste período de rupturas com o sistema tradicional. Um exemplo dessa instabilidade relaciona-se ao comportamento futuro dos consumidores frente à biotecnologia. A forte reação negativa dos consumidores aos OGM's pode se alterar com o lançamento de novas variedades, com fins farmacêuticos ou nutricionais. Isto implicará um novo arranjo organizacional e institucional.

Uma outra linha de pesquisa sugerida seria a de tentar mensurar os custos relacionados à preservação de identidade nos diversos segmentos da cadeia produtiva. Esses valores seriam de grande importância para o confronto com os níveis de incentivos requeridos para estímulo dos agentes, assim como na determinação dos impactos distributivos ao longo do sistema. Os efeitos para o consumidor final também poderiam ser mais bem avaliados.

Finalmente, ainda poder-se-iam sugerir estudos semelhantes ao deste trabalho, porém com enfoque em outro elo do sistema agroindustrial. A análise envolvendo a relação produtor-agroindústria poderia ser deslocada para, por exemplo, o eixo indústria-supermercado-consumidor, para produtos que requeiram PI. Questões como rotulagem, reconhecimento e interpretação correta dos selos de certificação por parte dos consumidores, canais de distribuição e instrumentos de tecnologia de informação, como os negócios 
entre empresas na WEB (conhecidos como business-to-business) poderiam ser melhor explorados neste tema.

Processos de certificação e rastreabilidade já são uma realidade. Tornaram-se fundamentais na medida em que a ciência permitiu grandes avanços na alteração dos atributos de plantas e animais, ao mesmo tempo que o consumidor passou a exigir mais qualidade e informação. Vivenciamos o limiar de uma era de novos e importantes desafios, que irão demandar transformações profundas e mecanismos de adaptação aos novos arranjos organizacionais e institucionais do sistema agroindustrial, que já começam a ser desenhados. 


\section{REFERÊNCIAS BIBLIOGRÁFICAS}

ANDIA, L.H. Agribusiness citrícola e qualidade: uma abordagem Brasil - Japão. Laranja, v.16, n.2, p.1-35, 1995.

ANUÁRIO ESTATÍSTICO ABIOVE. São Paulo: Associação Brasileira das Indústrias de Óleos Vegetais, 1998. P.50

ARROW, K.J. The organization of economic activity: issues pertinent to the choice of market versus non-market allocation. In: JOINT ECONOMIC COMMITTEE. The analysis and evaluation of public expenditure: the PPB system. Washington: Government Printing Office, 1969. v.1: p.59-73.

AZEVEDO, P.F. Integração vertical e barganha. São Paulo, 1996. 220p. Tese (Doutorado) - Faculdade de Economia, Administração e Contabilidade, Universidade de São Paulo.

AZEVEDO, P.F.; GRAÇA, C.T.; LEONELLI, F.C.V.; SILVA, V.L.S. Genetic ID: identificação genética para produtos de exportação. In: SEMINÁRIO INTERNACIONAL PENSA DE AGRIBUSINESS, 10., São Paulo, 2000. O desafio das exportações. São Paulo : PENSA, 2000. 21p.

AZEVEDO, P.F. Nova economia institucional: referencial geral e aplicações para a agricultura. Agricultura em São Paulo, v.47, n.1, p.33-52, 2000. 
AZEVEDO, J.L. Impactos da biotecnologia na agricultura. Preços Agrícolas, v.14, n. $149_{1}$ p. 14-17, mar.1999.

BARZEL, Y. Measurement cost and the organization of markets. Journal of Law and Economics, v.25, p.27-48, April 1982.

BENDER, K.; HILL, L.; WENZEL, B.; HORNBAKER, R. Alternative market channels for specialty corn and soybeans. Urbana-Champaign : University of Illinois. Department of Agricultural and Consumer Economics, Feb.1999. 19p. (Projeto de Pesquisa $A E$ 4726, integrante do Projeto Regional: Marketing and Delivery of Quality Cereal and Oilseeds)

BIALOSKORSKI NETO, S. Cooperativas: economia, crescimento e estrutura de capital. Piracicaba, 1998. 256p. Tese (Doutorado) - Escola Superior de Agricultura "Luiz de Queiroz", Universidade de São Paulo.

BLOOMBERG News. Gazeta Mercantil. Finanças e Mercados, São Paulo, 29 nov. 2000. p. B-16.

BRESTER, G.W.; BIERE, A.; ARMBRISTER, J. Marketing identity preserved grain products: The case of American white wheat producers association. Agribusiness, v.12, n.3, p.301-308, 1996.

BROWN, M.H.; HAHN, D.E.; LARSON, D.W. Impacts of trade and technology on competitiveness: the case of high oil corn. / Apresentado ao IAMA World Food and Agribusiness Congress, Florença, 1999/

BUCCKWELL, A.; BROOKES, G.; BRADLEY, D. Economics of identity preservation for genetically modified crops. Wye, Inglaterra : CEAS Consultants, 1998. (CEAS 1745/GJB)

CESARE, C.F.; CORDEIRO, E. Emerge o mercado de teste para transgênico. Gazeta Mercantil. Finanças e Mercados, São Paulo, 1 nov. 1999. p.B-20. 
COKLIN, N. C.; THOMPSON, G. Product quality in organic and conventional produce: is there a difference? Agribusiness, v.9, n.3, p.295-307, 1993.

CORDIER, J.E. Required vertical coordination and derived risk management. I Apresentado ao IAMA World Food and Agribusiness Congress, Chicago, $2000 /$

DAVID, P.A; GREENSTEIN, S. The economics of compatibility standard: an introduction to recent research. Economic of Innovation and New Technology, n.1, p.1-2, 1990.

DIJKSTRA, R.F. Cadeia de produção de milho Waxy. ABC - Batavo, 1997.

DIMITRI, C.; JAECNICKE, E. Protection of property rights as unifying theory for agricultural contracts. / Apresentado ao American Consumer in Changing Food System, Washington, 2000/

FARINA, E.M.M.Q. Reflexões sobre desregulamentação e sistemas agroindustriais : a experiência brasileira. São Paulo, 1996. Tese (LivreDocência) - Faculdade de Economia, Administração e Contabilidade, Universidade de São Paulo.

FARINA, E.M.M.Q.; ZYLBERSZTAJN, D. Relações tecnológicas e organização dos mercados do sistema agroindustrial de alimentos. Cadernos de Ciência e Tecnologia, v.8, n.1/3, p.9-27, 1991.

FARINA, E.M.M.Q.; ZYLBERSZTAJN, D. Deregulation, chain differentiation, and the role of government. / Apresentado ao 1. Brazilian Workshop on Agri-Chain Management, Ribeirão Preto, $1997 /$ 
FARINA, E.M.M.Q. Padronização em sistemas agroindustriais. In: SEMINÁRIO INTERNACIONAL PENSA DE AGRIBUSINESS, 9., Águas de São Pedro, 1999. A gestão da qualidade dos alimentos. São Paulo: USP.PENSA, 1999. $79 \mathrm{p}$.

GRAÇA, C.T. Auditoria da cadeia brasileira de farelo de soja isento de material de origem geneticamente modificado, safra 1999-2000. Piracicaba, 2000. 84 p. (Relatório de estágio profissionalizante do curso de Engenharia Agronômica, Escola Superior de Agricultura "Luiz de Queiroz", Universidade de São Paulo)

EMPRESA BRASILEIRA DE PLANEJAMENTO DE TRANSPORTES. Corredores de transportes: proposta de ações para adequação da infraestrutura e para racionalização do transporte de granéis agrícolas. Brasilia: GEIPOT, abr.1997. 314 p. (Relatório de atualização)

GOLDBERG, R.A. Agribusiness coordination: a systems approach to the wheat, soybean and Florida orange economies. Boston: Division of Research. Graduate School of Business and Administration. Harvard University, 1968. 256p.

HAHN, D.E.; SCHUERMAN, W.S. Seed corn purchasing behavior of Ohio corn growers. Ohio Report, v.61, n.6, 1976.

HAHN, D.E.; LARSON, D.W.; THOMISON, P; CUPPY, S. Risks and returns in value added supply chains for specialty corn. I Apresentado ao IAMA World Food and Agribusiness Congress, Chicago, 2000/

HAUSEMMANN, P. ISO inside out: ISO and environment management. s.I. : WVWVWF International, June 1996. 19 p. (Discussion Paper) 
HAYENGA, M.; KALAITZANDONAKES, N. Structure and coordination system changes in the U.S. biotech seed and value-added grain market. I Apresentado ao IAMA World Food and Agribusiness Congress, Florença, $1999 /$

HAYES, D.; HAYENGA, M.; THOMPSON, S.J. Transaction costs economics and the evolving structure of agricultural production. I Apresentado ao IAMA World Food and Agribusiness Congress, Chicago, $2000 /$

HOBBS, J.E. Transaction costs and slaughter cattle procurement: processors' selection of supply channels. Agribusiness, v.12, n.6, p.509-523, 1996.

HOBBS, J.E. Measuring the importance of transaction costs in cattle marketing. American Journal of Agricultural Economics, v.79, n.4, p.1083-1095, Nov.1997.

HOBBS, J.E.; YOUNG, L.M. Closer vertical co-ordination in agri-food supply chains: a conceptual framework and some preliminary evidence. Supply Chain Management: An International Journal, v.5, n.3, p.131-142, 2000.

HUGHES, D. R. Breaking with tradition: building partnerships and alliances in the European food industry. Wye, Kent: Wye College Press, 1994.

JANK, M.S. Competitividade do agribusiness brasileiro: discussão teórica e evidências no sistema carnes. São Paulo, 1996. 195p. Tese (Doutorado) Faculdade de Economia, Administração e Contabilidade, Universidade de São Paulo.

JANK, M.S. Rastreabilidade no agribusiness. In: SEMINÁRIO INTERNACIONAL PENSA DE AGRIBUSINESS, 9., Águas de São Pedro, 1999. A gestão da qualidade dos alimentos. São Paulo: USP.PENSA, 1999. $79 \mathrm{p}$. 
JURAN, J.M.; GRYNA JR., F.M. Controle de qualidade: handbook. São Paulo: Makron Books, 1993. v.3.

KERR, W.A. Genetically modified organisms, consumer scepticism and trade law: implications for the organization of international supply chains. Supply Chain Management, v.4, n.2, p. 66-74, 1999.

KINDLEBERGER, C.P. Standards as public, collective and private goods. Kyklos, v.36, n.3, p.377-396, 1983.

KLEIN, B.; CRAWFORD, R.G.; E ALCHIAN, A.A. Vertical integration, appropriable rents and the competitive contracting process. The Journal of Law and Economics, v.21, n.2, p.297-326, 1978.

KRUEGER, A.; DOOLEY, F.; BERRUTO, R.; MAIER, D. Risk management strategies for grain elevators handling identity-preserved grains. I Apresentado ao IAMA World Food and Agribusiness Congress, Chicago, 2000/

LAZZARINI, S.G.; ZYLBERSZTAJN, D.; TAKAKI, F.S. Contractual innovations in the Brazilian live cattle futures market. / Apresentado ao 1. Brazilian Workshop on Agri-Chain Management, Ribeirão Preto, 1997/

LAZZARINI, S.G.; NUNES, R. Competitividade do sistema agroindustrial da soja. In: Competitividade do agribusiness brasileiro (compact disc). Brasilia: IPEA/PENSA/USP, 1998.

LAZZARINI, S.G Estudos de casos para fins de pesquisa: aplicabilidade e limitações do método. In: FARINA, E (Coord.). Estudos de casos em agribusiness. São Paulo: Pioneira, 1997. p.9-23. 
LOADER, R. Assessing transaction costs do describe supply chain relationships in agri-food systems. Supply Chain Management, v.2, n.1, p. 23-35, 1997. / Apresentado ao International Conference on Chain Management: agri-food business, 1995/

LOMBARDI, M.C. Rastreabilidade: exigências sanitárias dos novos mercados. I Apresentado ao 3. Congresso Brasileiro das Raças Zebuínas: Integração Da Cadeia Produtiva Pecuária, 1998/

MACHADO, R.T.M. Tecnologia da informação e competitividade em sistemas agroindustriais: um estudo exploratório. Revista Brasileira de Agroinformática, v.1, n.1, p.66-76, 1998.

MACHADO, R.T.M. Coordination in agribusiness: theoretical dimensions of the traceability concept. I Apresentado ao 6. World Soybean Research Conference, Chicago, 1999/

MACHADO, R.T.M. Rastreabilidade, tecnologia de Informação e coordenação dos sistemas agroindustriais. São Paulo, 2000. 224p. Tese (Doutorado) Faculdade de Economia, Administração e Contabilidade, Universidade de São Paulo.

MARIOTI, S; CAINARCA, G.C. The evolution of transaction governance in the textile-clothing industry. Journal of Economic Behavior and Organization, p. 351-374, 1986.

MARQUES, P.V. Economia da integração vertical na avicultura de corte do Estado de São Paulo. Piracicaba, 1991. 133p. Tese (Livre-Docência) Escola Superior de Agricultura "Luiz de Queiroz", Universidade de São Paulo. 
MARQUES, P.V.; SOUSA, E.L.L. Cenários dos sistemas agroindustriais de grãos no Brasil e novas formas de comercialização. In: AGUIAR, D.R.D.; PINHO, J.B. (Ed.). O agronegócio brasileiro: desafios e perspectivas. Brasília, 1998. P. 209 a 222.

MATTAR, F.N. Pesquisa de marketing: metodologia, planejamento, execução, análise. São Paulo: Atlas, 1993. v.1. 350 p.

MENEZES, V.B. A indústria da laranja: competitividade e tendências. Salvador: Fundação Centro de Projetos e Estudos, 1993.

MIGHEL, R.L.; JONES, L.A. Vertical coordination in agriculture, Washington : USDA. ERS, Feb. 1963. (Agricultural Economics Report, n.19)

MILGROM, P; ROBERTS, J. Economics, organization and management. New Jersey: Prentice Hall, 1992. 621 p.

NASSAR, A. M. Certificação no agribusiness. In: SEMINÁRIO INTERNACIONAL PENSA DE AGRIBUSINESS, 9., Águas de São Pedro, 1999. A gestão da qualidade dos alimentos. São Paulo: USP.PENSA, 1999. $79 \mathrm{p}$.

NEVES, M.F. Sistema agroindustrial citrícola: um exemplo de quase-integração no agribusiness brasileiro. São Paulo, 1995. 116 p. Dissertação (Mestrado) - Faculdade de Economia, Administração e Contabilidade, Universidade de São Paulo.

NORTH, D.C. Institutions, institutional change and economic performance. New York: Cambridge University Press, 1990. 152p.

NUNES, R. Certificação de produtos industriais. Agrocast - Agência Estado. www.agrocast.com.br (8 set. 1999). 
NUNES, R.; SOUSA, E.L.L. Terra preservada: coordenando ações para garantir a qualidade. In: SEMINÁRIO INTERNACIONAL PENSA DE AGRIBUSINESS: COMPETITIVIDADE NO SÉCULO XXI, 9., Águas de São Pedro, 1999. A gestão da qualidade dos_alimentos. São Paulo: USP.PENSA, 1999.

PERI, C.; GAETA, D. Designations of origin and industry certifications as means of valorizing agricultural food products. In: GOLDBERG, R.A. (Coord.). The European agro-food system and the challenge of global competition. Roma: ISMEA, June 1999. p. 59-68

PIERCE, F.J.; SANDLER, E.J. The state of site-specific management for agriculture. Madison : American Society of Agronomy, Crop Science Society of America. 1997.

POOLE, N.D. Change in the European food industry? A research agenda for marketing economists. Journal of International Food and Agribusiness Marketing, v.9, n.1, p.1-17, 1997.

POOLE, N.D.; GOMIS, F.J.D.C.; IGUAL, J.F.J.; GIMÉNEZ, V. Formal contracts in fresh produce markets. Food Policy, v.23, n.2, p.131-142, 1998.

SAES, M.S.M.; FARINA, E.M.Q. Associação brasileira da indústria de café (ABIC): ações conjuntas e novos desafios frente à reestruturação de mercado. IApresentado ao 8. Seminário Internacional PENSA de Agribusiness, Águas de São Pedro, PENSA/FIA/USP, 1998.

SAES, M.S.M.; JAYO, M. Competitividade do sistema agroindustrial do café. In: Competitividade do agribusiness brasileiro (compact disc). Brasília: IPEA/PENSA/USP, 1998.

SANS, P; FONTGUYON, G. Formes de coordination et qualité des produits: les effects de la modifiés. 
SCHROEDER, R. C. Incentive distortions in commodities markets: lessons from the soybean value chain. Revista Agrosoft, n.7, p.22-29, 1999.

SIFFERT FILHO, N. F. Citricultura e agroindústria: organizações e mercados. Rascunho, p.22, 1992.

SNIA. Programe de Recherche sur la pertinence et la faisabilitè d'une filière sans OGM: résulltas intermédiaires. Info-Dévelopment, dec, 1999.

SONKA, S. Information technology and the soybean sector. Revista Agrosoft, n.7, p.10-13, 1999.

SONKA, S. The state of the soybean Industry in the United States. In: WORLD SOYBEAN RESEARCH CONFERENCE, 6., Chicago, Illinois. Aug, 1999. Anais. Champaign: Superior Printing, 1999. p. 23-28.

SONKA, S.; COALDRAKE, K.F. Cyberfarm: what does it look like? what does it mean ? American Journal of Agricultural Economics, v.78, n. 5, p.1263$68,1996$.

SOUSA, E.L.L. Estudo do potencial do desenvolvimento de um mercado futuro no Brasil. Piracicaba, 1996. 122p. Dissertação (Mestrado) - Escola Superior de Agricultura "Luiz de Queiroz", Universidade de São Paulo.

SOUSA, E.L.L.; MARQUES, P.V. Estrutura de comercialização de grãos nos Estados Unidos e o papel dos mercados futuros. Resenha BM\&F, n.121, p.45-57, nov./dez. 1997.

SOUSA, E.L.L.; MARQUES, P.V. O modelo agroexportador de grãos da Argentina. Preços Agrícolas, v.12, n.144. p.17-24, out.1998.

SOUSA, E.L.L.; SAES, M.S.M.; AZEVEDO, P.F. Competitividade do sistema agroindustrial do milho. In: Competitividade do agribusiness brasileiro (compact disc). Brasília: IPEA/PENSA/USP, 1998. 
SOUZA, M.C.M. Algodão orgânico: o papel das organizações na coordenação e diferenciação do sistema agroindustrial do algodão. São Paulo, 1998. 187p. Tese (Doutorado) - Faculdade de Economia, Administração e Contabilidade, Universidade de São Paulo.

STREETER, D; SONKA, S; HUDSON, M. Information technology, coordination, and competitiveness in the food and agribusiness sector. American Journal of Agricultural Economics, v.73, n.5, p.1465-71, Dec.1991.

VERHEIJDEN, S. M.; ORTIZ, A.C. Agribusiness: prepare-se para mudanças. Gazeta Mercantil, São Paulo, 18 mar. 1999. p.3.

VILLELA, P.R. DE C. O impacto da internet nos agronegócios Revista Agrosoft, n.8, fev.2000.

WILLIAMSON, O.E. The economic institutions of capitalism : firms, markets, relational contracting. New York: Free Press, 1985. 449 p.

ZYLBERSZTAJN, D. Estrutura de governança e coordenação do agribusiness : uma aplicação da nova economia das instituições. São Paulo, 1995. Tese (Livre-Docência) - Faculdade de Economia, Administração e Contabilidade, Universidade de São Paulo.

ZYLBERSZTAJN, D.; FARINA, E. M. M. Q. Agri-system management: recent developments and applicability of the concept. I Apresentado ao 1. Brazilian Workshop on Agri-Chain Management, Ribeirão Preto, 1997/

ZYLBERSZTAJN, D.; NEVES, M.F. Illycaffè: coordenação em busca da qualidade. In: FARINA, E.M.M.Q. (Coord) Estudos de caso em Agribusiness. São Paulo: Pioneira, 1997. p.47-70. 
ZYLBERSZTAJN, D.; FARINA, E. M. M. Q. Strictly coordinated food-system: exploring the limits of the coasian firm. International Food and Agribusiness Management Review, v.2, n.2, p.249-265, 1999. 


\section{APÊNDICE}

\section{QUESTIONÁRIO - Roteiro básico para as entrevistas}

Descrição do setor, da empresa e da forma de negociação tradicional entre produtor e comprador (se via mercado, contratos ou integração vertical)

1. Quais foram as motivações que levaram a empresa a trabalhar com o produto?

2. Em relação ao produto tradicional, quais as especificidades desta transação relacionadas aos seguintes aspectos:

- O produto apresenta atributos específicos? Quais?

- Há especificidades relacionadas a aspectos temporais? de distância? de capacitação humana?

- Qual a freqüência da transação: maior, menor ou igual em relação ao produto sem diferenciação?

3. Quais os desafios e qual a forma utilizada pela empresa para resolvê-los? (destacar se, na visão da empresa, haveria alguma forma mais eficiente e por que não foi adotada)

- Qual a forma de fixação de preço?

- Como é feito o processo de busca e de seleção de produtores?

- Há custos de reconversão produtiva ou investimentos específicos para o produtor agrícola, armazenador, distribuidor, indústria ou varejo? 
- Quais os custos envolvidos na elaboração do desenho do contrato e renegociações?

- Há custos de monitoramento?

- A classificação oficial atende as necessidades do consumidor e/ou da agroindústria?

- Há custos adicionais para a classificação?

- Os atributos do produto são tangiveis ao consumidor ou agroindústria?

- Se não, como diminuir a assimetria informacional ao consumidor?

4. Haveria bens públicos e coletivos que permitiriam o aumento da eficiência da transação?

5. Arranjo contratual observado 